
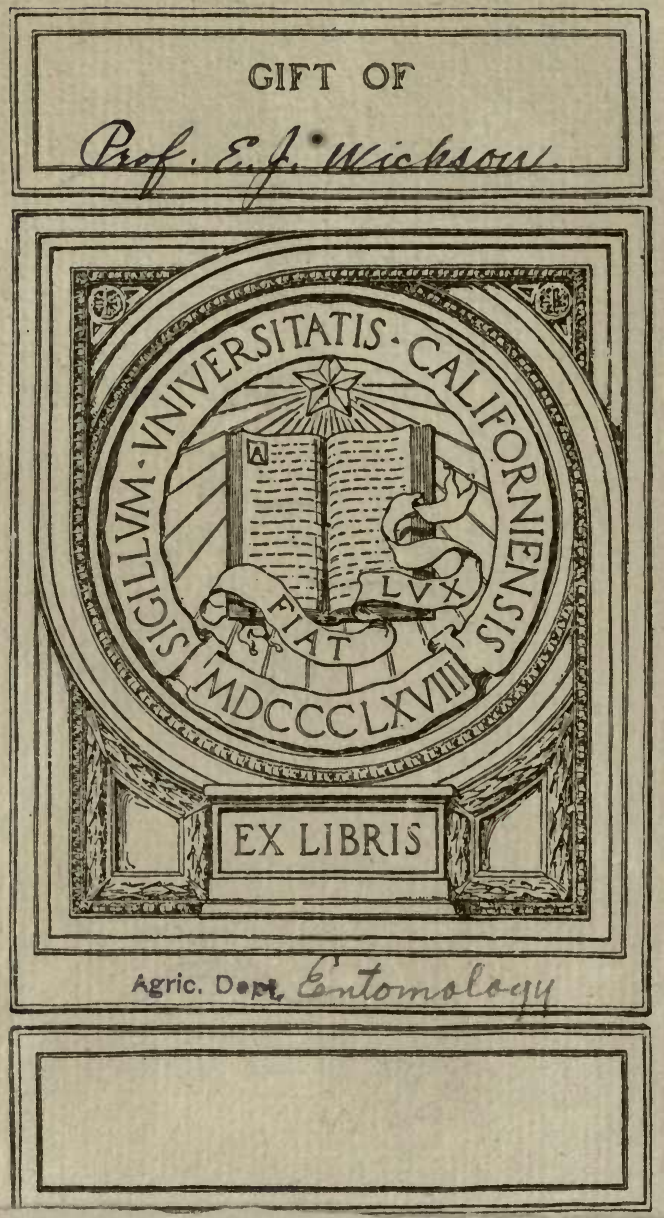
by.00ciarcan. 

SPRAYING CROPS 


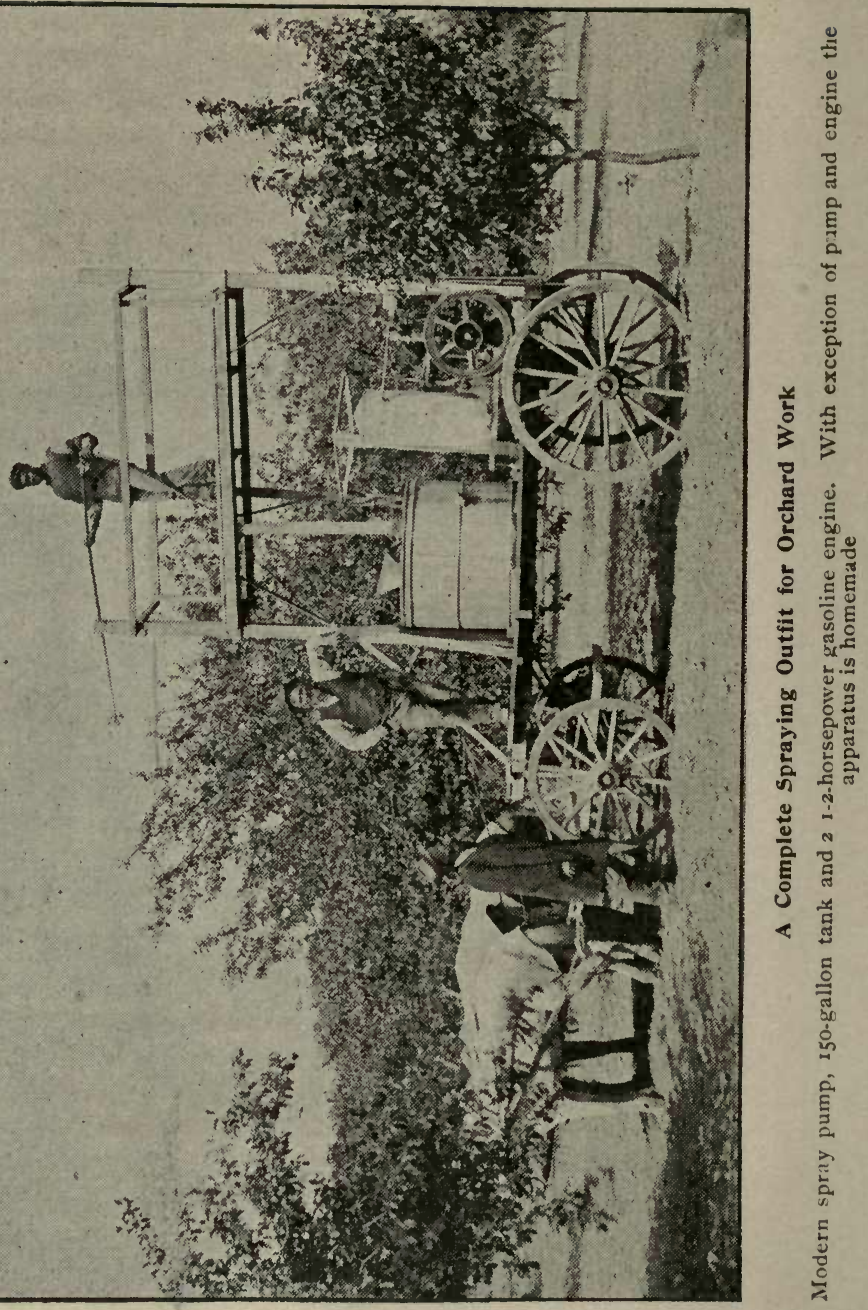




\title{
Spratying
}

\section{Why, When, and How}

\author{
BY
}

\section{CLARENCE M. WEED, D. Sc.}

Professor of Zoology and Entomology, New Hampshire

College of Agriculture and the Mechanic Arts

\section{ILLUSTRATED}

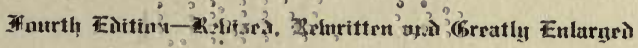


$D_{0}+n^{\infty} x$

COPYRIGHT 189i

BY CLARENCE M. WEED

COPYRIGHT 1903

BY ORANGE JUDD COMPANY

Agric.dept. (entomology) 
Spraying has noze come to be an established part of the work of fruit-growing.- L. H. BAILEY.

The time is now ripe for the declaration that profitable apple culture demands systematic spraying.-FREDERICK D. CHESTER.

Spray! Spray! Spray! Spray for insects and for fungous diseases. This is one of the secrets of successful fruitgrowing.-Delaware Farm and Home.

I believe in spraying, for I have tried and proven it. In many portions of our country to-day it is just as much a necessity as is underdraining, or fertilizing, or killing potatobugs.-MORTIMER WHITEHEAD.

The spray pump might well be adopted as the emblem of the fruit grower, and on it be inscribed that old legend: By this sign we conquer.-Hon E. L. Smith, Oregon.

Out of thirty-six tons of grapes last season I did not lose five pounds by rot, but I shall spray, rot or no rot. Spraying adds greatly to the health of the vines, and consequently to the size and beauty of the fruit.-JOHN BURROUGHS.

It should be remembered that in all cases success is dependent upon the exercise of proper judgment in making applications. Know the enemy to be destroyed; know the remedies that are most effective; and, finally, apply. them at the proper season. Be prompt, thorough and persistent. Knowledge and good judgment are more necessary to success than any definite rules.-E. G. LODEMAN. 



\section{Preface to Second Edition}

This little manual has been prepared for the purpose of aiding owners of spraying machines to use them to best advantage. The practical results of the most recent investigations and experiments have been embodied in it; and technical terms, so far as possible, have been excluded.

The development of the practice of spraying crops furnishes a striking illustration of the practical results agriculture may derive from scientific investigation and accurate experimentation. Little more than a decade has passed since Professor A. J. Cook, then of the Michigan Agricultural College, began his experiments in spraying apples to prevent the injuries caused by the Codling Moth-experiments which first proved to the horticultural public that the remedy was safe and sure-and to his enthusiastic advocacy of the process American fruit-growers are largely indebted for the introduction of spraying machinery. The success which followed spraying for the Codling Moth naturally led to experiments in spraying for other insects, and later for fungous diseases; our early knowledge of remedies for the latter being largely due to the efforts of Messrs Scribner and Galloway, of the United States Department of Agriculture. The establishment of the state experiment stations has greatly aided the acquisition and diffusion of information upon the whole subject. 
The sources of those illustrations on the following pages which are not original with the author, are indicated in the legends below the pictures.

\section{M. W.}

New Hampshire College of Agriculture and the Mechanic Arts. DURHAM, March, I895. 


\section{Preface to Fourth Edition}

In the revision for the present edition an attempt has been made to bring this little book up to the best knowledge and practice of the day. I am under special obligations to Professor L. R. Jones for the revision of the part treating of potato enemies, to Professor F. A. Waugh for reading the proof throughout, and to $\mathrm{Mr} \mathrm{W}$. E. Britton for the loan of the electrotype used on page Io6. Of course I am under obligations also to the great number of workers who have made possible the wonderful advance in spraying operations during recent years. A book like this can only hope to be a compilation of the results of many minds, and I have not hesitated to draw freely from many sources, giving due credit so far as practicable. To all who have thus contributed to the possible usefulness of the book I extend cordial thanks.

$$
\text { C. } M . \text { W. }
$$

Durhàm, N. H., May, 1903. 



\section{Contents}

Principles of Spraying.......

\section{PAR'T I}

SPRAYING THE LARgER Fruits

Apple .................. $57 \quad$ Peach................ 73

Plum................... 69 Pear................. 76

Cherry .............................................. 8o

\section{PART II}

Spraying Small Fruits ani Nursery Stock Strawberry ............. $85 \quad$ Grape................. 95 Currant and Gooseberry.. $90 \quad$ Raspberry ................ 97 Nursery Stock .................................... 99

\section{PART III}

Spraying Shade-Trees, Ornamental Plants ani FLOWERS

Shade Trees............. I07 Rose.................. II

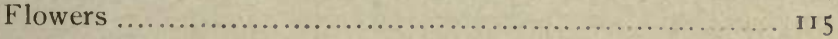

\section{PART IV}

Spraying Vegetables, Field-Crops and Domestic ANimals

Potato ................. II 19 Asparagus .............. I 26

Cabbage ................ I24 Grain Crops............. I29

Domestic Animals ................................... 132 



\section{SPRAYING CROPS}

\section{PRINCIPLES OF SPRAYING}

HABITS OF INSECTS-DEVELOPMENT OF PARASITIC GROWTH-MIXTURES AND METHODS EMPLOYED

Growing plants are liable to injury from two classes of organisms, - namely, noxious insects and parasitic fungi. Although these tiny foes are often considered too insignificant to merit serious attention, they annually destroy about $\$ 500,000,000$ worth of crops in the United States. By an intelligent use of the spraying machine-a simple apparatus by which certain substances that destroy insect and fungous life may be distributed over the surfaces of plants - a large proportion of this loss may be prevented at comparatively slight expense. The object of this little manual is to indicate why, when, and how to spray, to get the best results.

The philosophy of spraying will be better understood if one has a general knowledge of the habits and methods of development of the insect and fungus pests against which the spraying machine is used. Nearly all of these organisms are weaker and easier to destroy at some one period of their existence than at any other: consequently, a knowledge of their habits and history is often necessary to success.

\section{SPRAYING AGAINST INSECTS}

The insect against which the spraying machine has been most generally used in the northern United 
States is the coding Moth-or Apple Worm-the little white worm that one too often finds near the core of the dessert apple. The parent of this little pest is a small chocolate-colored moth (represented at $f$ and $g$ ), which appears in spring soon after the blossoms have fallen and deposits its eggs in various places upon the young apples as well as upon the adjacent leaves. In about a week these eggs hatch into

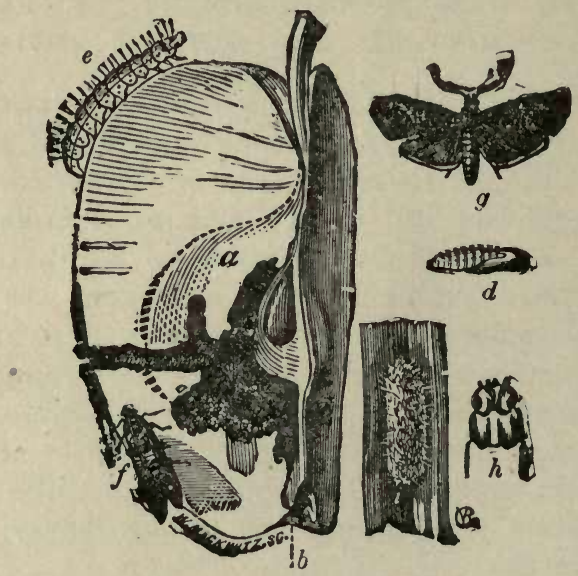

Codling Moth

$a$, injured apple; $b$, calyx where young larva generally enters; e, larva; $d$, pupa; $i$, cocoon; $g, f$, moth; $h$, head of larva. (After Riley)

young larvae which often nibble a little of the green surface of the leaf or the fruit before they crawl into the little calyx cup at the outer end of the apple to burrow into the pulpy part. Some of them enter at other places. Once inside the larva continues feeding as the apple develops, constantly increasing in size, until, at the end of three or four weeks, it is about three-fourths of an inch long, and appears as represented in $e$. It has now finished its caterpillar 
growth, and, leaving the apple, it finds some crevice in the rough bark, where it spins a slight cocoon, in which it changes to the pupa or chrysalis state. A fortnight later it emerges from the cocoon as a full-fledged moth, like the one which laid the original egg. Thus the curious life-cycle is completed. There are generally two broods of the worms each season.

By means of the spraying machine the fruitgrower is able to place in the calyx ends of the young apples a few particles of poison, so that when the newly-hatched worm nibbles at the skin, the chances are that it will eat one of these particles, and thus cut short at the outset its own career. To do this the fruit-grower usually mixes a quarter of a pound of Paris green or some similar insecticide with a barrel of water, and then, having the barrel in a wagon, he drives along the rows of apple trees just after the blossoms have fallen off, and sprays them. The little particles of poison are thus distributed over the tree in a spray, and when the water in which they are suspended evaporates, they are left high and dry upon the leaves and fruit, where they remain for several weeks a menace to insect enemies, until the combined action of rain and dew, wind and sunshine, dissipates their poisonous properties. The spraying is most effective if done just after the petals fall, when the blossom end of the apple is wide open. As the young fruit enlarges, the parts of the calyx close up, holding the poison inside so it is ready for the little worms when they attempt to eat their way to the core. Probably many of them also get some of the poison when they take their first meal on the green surface of the leaf or fruit. If the first brood of worms are thus quite generally destroyed, there is no necessity, usually, to spray for the second brood; because their 
would-be parents having died in infancy, the worms of the second brood do not appear upon the scene.

Another insect against which the spraying machine is often used is the Plum Curculio. This pest has been for many years one of the most destructive enemies of the plum-grower, and is the cause of the worminess and premature dropping of the fruit, with which so many owners of plum trees are familiar. The adult Curculio is a small, hard beetle (shown magnified at $c$ ), which appears in the plum

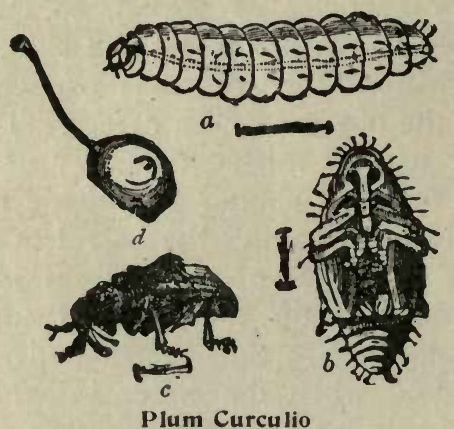

$a$, larva ; $b$, pupa; $c$, beetle, magnified ; $d$, plum, showing crescent mark.

(After Riley)

orchard early in spring, and feeds upon the foliage and flowers until the fruit is well formed. It then attacks the young plums, gnawing at them to satisfy its hunger, and cutting crescent-shaped marks in the skin to deposit its eggs $(d)$. In a short time these eggs hatch into little grubs that feed upon the pulp of the fruit, gradually working toward the pit. In a few weeks they become full-grown $(a)$, by which time the infested plums have generally fallen to the ground. The larvae then leave the fruit, and, entering the soil a short distance, change to pupae $(b)$. A little while later they again change and come forth 
as perfect beetles. There is but one brood in the season.

As the eggs of this insect are deposited beneath the skin of the fruit, it is manifestly impossible to reach the larvae by spraying. But by coating the young fruit and foliage with particles of poison we can kill many of the parent beetles before they insert the eggs, and thus part of the plums will escape. This is not a perfect remedy, however, except perhaps in large orchards, and must often be supplemented by jarring the trees.

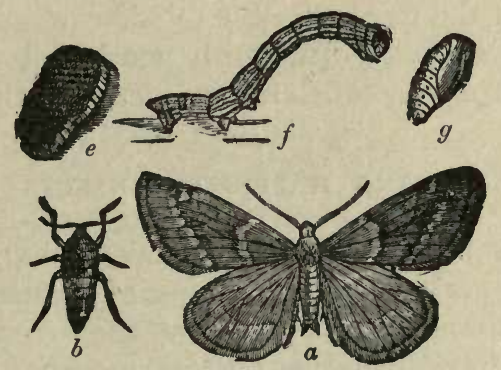

Canker Worm

$e$, eggs; $f$, larva ; $g$, pupa ; $a$, male moth ; $b$, female moth. (After Riley)

Besides these two insects affecting the fruit of orchard trees, against which the spraying machine is especially used, there are many enemies of the foliage which are open to destruction by similar means. One of the worst of these pests is the Canker Worm, which at more or less frequent intervals during the last century has scourged both orchard and shade trees in many parts of the United States and Canada. It is represented in its different stages in the picture above. The worm or larva hatches from masses of small cylindrical eggs (e) deposited upon the bark of the tree. It feeds upon the soft parts of the leaves, causing a badly infested tree to appear brown and 
seared, as if scorched by fire. These worms continue feeding for several weeks before becoming full grown; they then descend to the ground, burrow into the soil a short distance, and spin silken cocoons, within which they change to the pupa or chrysalis state and later emerge as moths. The two sexes of the moths differ greatly: the male $(a)$ has large, welldeveloped wings, while the female $(b)$ is wingless. The latter is of an ash-gray color. On emerging from the chrysalis, she crawls to the base of the tree, and ascending the trunk, deposits eggs on the twigs or branches of the tree.

The Canker Worm, with nearly all other leafeating caterpillars, falls an easy victim to the spraying machine.

\section{FEEDING HABITS OF INSECTS}

Insects take their food in two ways: some bite and others suck. The three species mentioned under the last heading are examples of those insects which take their food by biting, piece by piece, the tissues of leaf, stem, or fruit of their host-plant. Because of this they may be destroyed by placing particles of poison upon the surface of the plant. A large proportion of the injurious insects have such biting mouth-parts; but there is also an important class which have instead of jaws a pointed beak that they push into the cells of the plant, and suck out the sap. Insects of this kind cannot be destroyed by coating the food-plant with particles of poison, for such particles will not enter their alimentary system; consequently, one must use against them some insecticide which kills by contact, either affecting the general surface or reaching the interior through the breathing - tubes. The former are called Contact Poisons and the latter Trachcal Poisons. Kerosene is the most 
important of the contact poisons and pyrethum or insect powder is a good example of a tracheal poison, although the various vapor insecticides, like carbon bisulphide and hydrocyanic acid gas, also belong here.

\section{DEVELOPMENT OF PARASITIC FUNGI}

Many other instances of the usefulness of the spraying machine in controlling noxious insects will be found on the later pages of this little book. To illustrate the theory of its use against the fungus enemies of crops, as well as the life history of the parasitic fungi themselves, we may instance the Downy Mildew, which causes the Brown Rot of grapes.

The Brown Rot of grapes is a fungous diseasethat is, it is a diseased condition of the foliage or fruit due to the presence of a fungus. This fungus is a minute, parasitic plant that develops at the expense of the tissues of the grape, thus causing blighting of the leaf and decay of the fruit. It attacks all the green parts of the vine, including the young shoots, as well as the leaves and berries; and, like other fungi, reproduces by means of spores-minute bodies corresponding in function to the seeds of flowering plants.

When one of these spores falls upon a moist leaf its contents divide into a number of distinct particles which escape through an opening in the spore-wall. Each of these particles moves about in the drop of water on the leaf for a few minutes, then comes to a standstill and germinates by sending out a little tubesomewhat as a kernel of corn in moist soil sends out its germinating radicle-and this tube penetrates the epidermis or skin of the leaf. Once inside, the tube continues to grow, pushing about between the cells of the leaf, and forming what is called the mycelium or vegetative portion of the fungus, which may be likened 
to the roots of the higher plants. As there is little nourishment to be obtained between the cells, the mycelium develops minute processes which push through the cell walls and absorb the cell contents. A small section of an affected leaf, greatly magnified, is represented in the accompanying figure, the unshaded double-walled spaces representing the leaf cells, the shaded part between the walls the mycelium of the fungus, and the projections marked $a, a$, the processes or suckers that penetrate the cells.

After this mycelium has developed in the leaf for some time, it is ready to produce its spores. Conse-

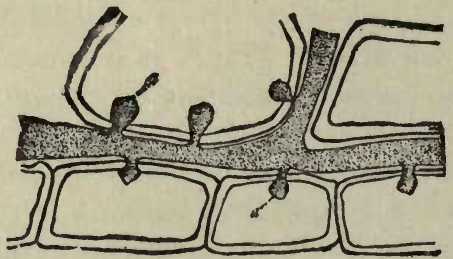

Section of Leaf Showing Mycelium of Fungus Magnified. (After Farlow)

quently it sends out through the breathing pores or stomata of the leaf its fruiting branches. These bear upon their tips small oval bodies which are the spores. Some of these fruiting branches are represented magnified on the next page. The "mildew" visible to the naked eye is composed of these fruiting branches and their spores. It only develops under certain atmospheric conditions; so that the mycelium may exist in the affected parts of the vine for some time before this outward manifestation of its presence occurs. Besides the spores above described, which are produced during the summer season, and consequently are called summer spores, there is developed in autumn a different class of spores, by which the fungus passes through 
the winter. Hence, these latter are called the winter spores.

It is evident from the above account of this fungus parasite, that remedial or preventive measures are useless after the enemy has become established within the tissues of the plant. But its ingress

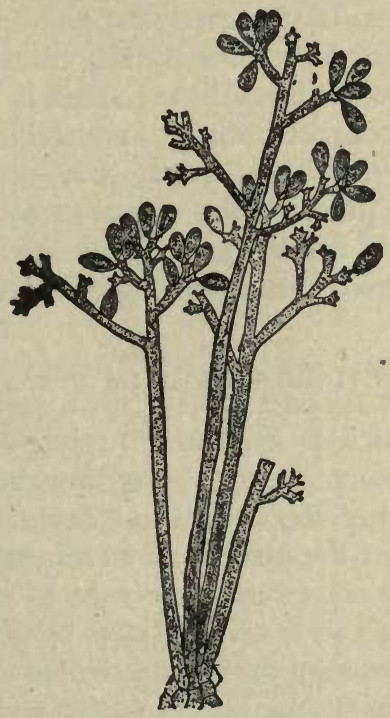

Fruiting Branches

Greatly magnified

may be prevented by coating the green parts of the vine with some substance having a destructive effect upon fungus spores. The salts of copper have such an effect, and in consequence have come into general use as fungicides.

From the foregoing illustrations the reader will have learned that spraying is simply an easy and practical method of distributing certain substances having 
a destructive effect upon insect and fungus life over the outer surfaces of trees, shrubs, vines, and herbaceous plants. These substances are usually applied in a finely powdered condition, and the tiny particles stand guard over the plants, killing with remorseless certainty any insect or fungus pest that attempts to pass through their lines to reach the plant. The particles themselves do not enter the plant, but remain on the outside until driven off by the combined action of wind, rain, dew, and sunshine. This is not true, however, of the contact-killing insecticides, which are applied directly to the offending insects and do not remain on the plant in an effective condition.

Substances used to destroy insects are called insecticides; those used to destroy fungi are called fungicides.

\section{INSECCTICIDES USED IN SPRAYING}

The insecticides used in spraying may be broadly divided into two classes: (I) internal poisons, or those which take effect by being eaten along with the ordinary food of the insect; and (2) external irritants, or those which act from the outside,-penetrating the breathing pores, or causing death by irritation of the skin. The most important insecticides are the poisons. Of these the most popular are the various combinations of arsenic.

Paris green is a chemical combination of arsenic and copper, containing about 58 per cent of arsenious acid; about 31 per cent of copper oxide and Io per cent of acetic acid. Technically it is called copper aceto-arsenite. It is almost insoluble in water; but there is often a small percentage of it soluble, and to prevent the injury this may do to foliage it pays to add a little fresh lime water (made by slaking fresh lime in water) to the spraying mixture. It may be 
used in spraying potatoes, apple trees, and most shade trees, at the rate of four ounces to 50 gallons of water. On stone fruits, use half this strength, unless lime is added, although in the case of peaches great care must be used if Paris green is applied. Arsenate of lead is safer. Paris green is a heavy powder, and does not stay long in suspension; hence it must be kept constantly stirred to prevent its settling to the bottom of the vessel. Buy Paris green in as finely powdered condition as possible, and get a reliable brand. Paris green is sometimes adulterated with arsenious acid, which gives a larger per cent of soluble arsenic than should be present. Gypsum or calcium sulphate is also often used as an adulterant. Most experiment stations are able to give the names of reliable brands of Paris green.

Color Tests for Paris Green-Upon this subject Mr A. V. Stubenrauch says in a bulletin of the Illinois Experiment Station: "Perhaps the simplest test to determine whether a green has been extensively adulterated is the color test. Pure Paris green has a bright green color, a shade or two lighter than emerald. Any samples which have a dull or a pale, washed-out appearance should at once be discarded without further question. By placing a small quantity in, say a homeopathic vial, and tapping the latter gently on the bottom or side, adulterants can be made to separate from the green, and can then be seen as white streaks or patches against the glass sides of the vial. The pure green remains bright green against the glass. In connection with the color test, Professor Woodworth of the California Station has devised the following simple test, which can be made by anyone and which will show immediately if the sample is worthy of any further consideration: Place upon a clean glass plate a small quantity of green, what one can easily 
pick up on the point of a penknife; tilt the plate at a slight angle and gently tap the edge, just enough to cause the green to flow down leaving a streak across the plate. If the green is of good quality, the streak will be a bright, light emerald green; if adulterated, a whitish or a sickly dull green. Any samples which exhibit the latter are either adulterated or of low grade and as such are not worthy of further consideration."

Arsenate of Lead-This poison has recently come into general use as an insecticide. It has many advantages as it is a very fine insoluble powder, that remains in suspension a long time and does not burn the foliage even when applied at the rate of 3 or more pounds to 50 gallons of water. It also adheres to the foliage better than Paris green and may be seen upon the leaves more readily so that the thoroughness of the spraying may be more easily determined. On the other hand it is rather slow in its action. It should be bought in the form of a thick paste. "For the garden or for the small orchard," writes Professor John B. Smith, "this arsenate of lead in paste form is the most convenient and reliable arsenical poison that we have. There is no danger of using too much of it, and it can be employed on plants of all kinds. I used it on my roses to destroy the slugs and applied it on all other plants that were subject to caterpillar attack. It has the advantage of whitening the foliage somewhat, so that its presence is easily recognizable, and it has lasting qualities superior to any of the other arsenical poisons known to me. In the peach orchard there is nothing so good if leaf-eating insects are to be combated." The forms of arsenate of lead upon the market are Bowker's Disparene and Swift's Arsenate of Lead.

London purple generally contains nearly the same percentage of arsenic as Paris green; but the arsenic 
is often in a more soluble form, and consequently London purple is more likely to injure foliage than Paris green, unless lime is added. It is a finer powder than the green, and remains in suspension in water longer. It is also cheaper. Before using, the soluble arsenic should be made insoluble by the addition of lime water. One of the best ways to do this is to add three-fourths of a pound of lime to a pound of London purple, and thoroughly mix them in a gallon of hot water, allowing the mixture to stand two hours and keeping it hot during this time if it can be conveniently done. In this way the soluble arsenic will be rendered insoluble, and the London purple may be used at the rate of 4 or 5 ounces to a barrel of water. Or the London purple may be added to the water as usual, and about 2 gallons of fresh milk of lime (made by slaking lime in water) strained into the barrel. If allowed to stand an hour, all the soluble arsenic is more likely to be rendered insoluble than if used at once. After London purple has been thus treated with lime it can safely be applied to tender foliage at a strength of 4 ounces to 50 gallons of water. Both London purple and Paris green may be added to the Bordeaux mixture ( 4 ounces poison to 50 gallons mixture), as described more fully elsewhere, and then the treatment with lime is not necessary.

Scheele's Green is another arsenical insecticide recently placed on the market. According to a bulletin of the United States Department of Agriculture, it "is similar to Paris green in color, and differs from it only in lacking acetic acid; in other words, it is a simple arsenite of copper. It is a much finer powder than Paris green, and therefore more easily kept in suspension, and has the additional advantage of costing only about half as much per pound. When properly washed and prepared by the manufacturers it is 
less harmful to the foliage even than Paris green, is quicker in effect, and should supplant the latter as an insecticide. It is used in the same way and at about the same strength as Paris green."

Hellebore is a vegetable poison, and kills both by contact and by being eaten. It may be applied in water, I ounce to 3 gallons, or I pound to a barrel. It is especially excellent in destroying the imported currant worm.

Pyrethrum, or Insect Powder, is made from the powdered flowers of plants of the genus Pyrethrum. The greatest obstacle to the use of Pyrethrum has been the difficulty in obtaining the pure, fresh article. After long exposure to the air it loses much of its insecticidal value. It is used mainly as a dry powder or in water ( $\mathrm{I}$ ounce to 3 gallons); but may also be used in the form of a tea, or a decoction, a fume, or an alcoholic extract diluted.

Arsenite of Lime-Persons having a large amount . of spraying to do often use this in place of Paris green, as it is much cheaper. It is made by boiling for 15 minutes or more

White arsenic $\ldots \ldots \ldots \ldots \ldots \ldots \ldots .2$ pounds

Salsoda $\ldots \ldots \ldots \ldots \ldots \ldots \ldots \ldots \ldots, 8$ pounds

Water $\ldots \ldots \ldots \ldots \ldots \ldots \ldots \ldots, 2$ gallons

After the arsenic is dissolved this makes a stock solution which may be used at the rate of I pint to a barrel of water, adding also 2 pounds of freshly slaked lime. The chief objection to this is in the danger of having white arsenic around the premises. It looks so much like flour, baking powder and other domestic powders that it is dangerous to the family.

Kerosene-Pure kerosene has lately come into use as an insecticide for scale insects, especially the San José scale. It is to be applied only to dormant. 
trees in winter, and must be used with care and discretion in order not to kill the trees. It is to be sprayed on until the bark is thoroughly. moistened, but spraying should cease before the kerosene begins to run down the branches. The Vermorel nozzle with one-twentieth-inch aperture is recommended for this work. Apparently there is especial danger of injury to the trees in the case of the peach.

Kerowater Sprays-During the last few years considerable progress has been made in the making of apparatus for applying kerosene in mechanical mixture with water. Essentially this consists in having the kerosene in one receptacle and the water in the other and bringing the two together at the nozzle in such a way that the two will combine in the spray applied. In much of the apparatus now upon the market, the two liquids enter the same hose at the pump so that there is an opportunity for more or less separation before the nozzle is reached, a fact which leads to inequality in the percentages of kerosene in the spray at different times. The longer and larger the hose the greater the danger. Consequently the small bucket and knapsack kerosene and water machines are much more likely to give satisfaction than the large barrel machines.

As a matter of fact the kerosene and the water should reach the nozzle through separate lines of hose so that there will be no opportunity for such inequalities as the present system involves. In some of the best types of barrel sprayers this principle is now adopted.

There is no question that these kerowater sprays have many advantages, and are very useful in destroying many sorts of insects.

Kerosene Emulsion-According to the RileyHubbard formula in general use this is prepared by 
adding 2 gallons of kerosene to I gallon of a solution made by dissolving $1 / 2$. pound of hard soap in $I$ gallon of boiling water, and churning the mixture by forcing it back into the same vessel through a force pump with a rather small nozzle opening throwing a straight stream, until the whole forms a creamy mass, which will thicken into a jelly-like substance on cooling. The soap solution should be hot when the kerosene is added, but of course must not be near a fire. The emulsion thus made is to be diluted before using, with nine or ten parts of water to one part of emulsion. The amount of dilution varies with different insects. Soft water or rain water should be used in diluting. If this cannot be obtained add a little lye or bicarbonate of soda. For use against scale insects potash whale oil soap is recommended.

Crude Petroleum-This substance has been used to a considerable extent for winter treatment for the San José scale. It is sprayed upon the bark as recommended for pure kerosene and seems to remain on longer in effective condition.

Lime, Salt and Sulphur Wash-This has lately become the most generally recommended insecticidc for use against the San José scale. According to Professor J. B. Smith the formula generally used in New Jersey is :

Stone lime..$\ldots \ldots \ldots \ldots \ldots \ldots$......... 50 pounds

Flowers of sulphur........... 50 pounds

Stock salt................... 50 pounds

Water $\ldots \ldots \ldots \ldots \ldots \ldots \ldots \ldots \ldots \ldots \ldots$. 50 gallons

"Slake the lime with hot water, enough to do it thoroughly, add the sulphur, stir well, and boil for at least an hour, adding water as necessary. Then add the salt, boil at least fifteen minutes more, and dilute to make the I5O gallons, In boiling use no 
more water than necessary to make a fluid mass. Strain through a gunny sack and apply hot.

"The main point to be insisted on is that the mixture be thoroughly boiled, so as to obtain the complete combination of the sulphur and lime. Hogscalders were generally used last winter, but in at least one case a small steam boiler proved economical and satisfactory. Where large quantities of the mixture are to be prepared, the steam boilers will probably prove most convenient."

For Georgia, Mr W. M. Scott, state entomologist. gives the following directions:

"This wash may be prepared by combining lime, salt and sulphur in several different proportions, but the following appears to be the generally accepted formula :

Quicklime $\ldots \ldots \ldots \ldots \ldots \ldots \ldots . \ldots . \cdots 30$ pounds

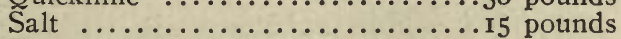

Flowers of sulphur...........20 pounds

Water to make 60 gallons.

"Slake half the lime carefully and place it in a large kettle with 25 gallons of water; grind the sulphur up with a little water, breaking the lumps as fine as possible by passing through a sieve and add to the lime; boil. As it boils the liquid will gradually become thinner and thinner, the lime and sulphur dissolving simultaneously to form a deep orange-red solution. When the sulphur has apparently all entered into solution, which may take two hours or more, slake the remainder of the lime, add to it the salt, and pour the two into the lime and sulphur solution. Boil the whole for from half an hour to an hour longer, strain, and dilute with warm water to 60 gallons. Do not let it become thoroughly cold, but spray while yet warm. 
"The principal care in making up this wash is to make sure that the sulphur is thoroughly dissolved. Flowers of sulphur is apt to be more or less lumpy, and these lumps are very difficult of solution. The more thoroughly the stphur is ground up with water before being boiled with the lime, the less time it will take in boiling.

"An iron kettle must be used if the boiling is done directly over a fire. A better and cheaper way, whenever a head of steam is available, is to place the sulphur, lime and salt together in a barrel half full of water, conduct the steam through a pipe to the bottom of the barrel and boil for two or three hours, with occasional stirring, to make sure that nothing is settling. If a boiler is convenient, a pipe might be so arranged as to conduct steam to a number of barrels at once."

Resin Soap-This substance is used for scale insects, and to add to Bordeatux mixture for asparagus rust. The soap is made by dissolving 7 pounds salsoda (washing soda) in 5 gallons of boiling water. Then add Io pounds resin and boil until the resin is dissolved. This will require half an hour or more. The result will be a yellow soap in the lower part of the vessel with a brownish liquid above. The latter is to be poured off, and the soap diluted as needed. Fish-oil Soap-Professor J. B. Smith and others report excellent results in the use of this substance against plant-lice and similar insects. The soap is on the market at about 12 cents a pound, but, according to Professor Smith, it can be made much more cheaply by the following formula:

Hirsh's crystal potash lye.......... I pound

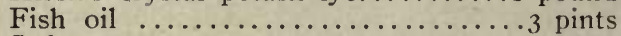
Soft water.................. 3 gallons 
Dissolve the lye in the water, heat to boiling, and then add the oil. It should be boiled about two hours, and when done water can be added to make up for the loss by evaporation. For use as an insecticide it is made into a dilute suds by dissolving I pound of soap in 8 gallons of water. It is less liable to injure foliage than kerosene emulsion.

Lime Spray is made by slaking a half-peck or a peck of fresh lime in water, and pouring into a barrel nearly full of water, straining the lumps out as it enters the barrel. By means of this and the spray pump, trees and vines may be literally whitewashed. It is useful in mechanically coating plants so that flea-beetles, and perhaps other insects, will not molest them.

Tobacco Decoction-This is made by boiling refuse tobacco stems or dust in water, or pouring boiling water over them. This gives a concentrated liquid, which is to be diluted with cold water, until there are two gallons of water for each pound of tobacco used. It is a good remedy for plant-lice. A stronger formula, recommended by Professor M. V. Slingerland, is to steep 5 pounds of tobacco stems in 3 gallons of water for 3 hours; then strain and dilute with enough water to make 7 gallons, when the decoction is ready to use.

Whale-oil Soap-Dissolve in water at the rate of 2 ounces soap to I gallon water. This is good to destroy plant-lice, rose slugs, etc. Good's potash soap No 3 seems to be the best whale-oil soap for insecticidal purposes.

\section{FUNGICIDES USED IN SPRAYING}

The principal fungicides used in spraying are certain salts of copper, especially the sulphate of copper and the carbonate of copper. These substances 
were first experimented with on a large scale in France, and gave such satisfactory results that they were adopted in a practical way by many vineyardists. In America they have been used for this purpose only about twenty years; yet, thanks to numerous investigations and experiments, their efficiency is well attested, and they are in practical use over a large territory. Their principal combinations are indicated below :

Bordeaux Mixture-This fungicide originated in France, and has become one the leading combinations of copper salts. Since its introduction into America there has been a constant tendency to dilute the mixture more and more. The results from the diluted mixtures have been apparently as good as from those of full strength, and of course the cost has been proportionately lessened. The different formulas are indicated below:

Original or 22-Gallon Formula-Dissolve 6 pounds copper sulphate in I gallon hot water in an earthen or wooden vessel. In another vessel slake 3 pounds fresh lime in I gallon water. Strain the latter, and add to 20 gallons water. Now pour in the dissolved copper sulphate and mix thoroughly. Keep the mixture stirred while using. This strong mixture is now seldom used.

Fifty-Gallon Formula-In 1889, while at the Ohio Experiment Station, I experimented with potato blight by diluting this mixture a little more than half, using 6 pounds copper sulphate and 4 pounds lime to 50 gallons water, instead of 22 gallons. This was applied to a number of plants besides potatoes, and apparently gave as good results as undiluted mixtures. The same formula was also successfully used in 1890 , and has been so generally adopted since, that it is now the standard formula. 
The most complete practical directions for making the Bordeaux mixture are those published by Professor B. T. Galloway, United States Department of Agriculture, in Farmers' Bulletin No 38, which I quote at length:

"It has been found," writes Mr Galloway, "that the method of combining the ingredients has an important bearing on both the chemical composition and physical structure of the mixture. For example, if the copper sulphate is dissolved in a small quantity of water and the lime milk diluted to a limited extent only, there results, when these materials are brought together, a thick mixture, having strikingly different characters from one made by pouring together weak solutions of lime and copper sulphate. It is true, furthermore, that if the copper sulphate solution and lime milk are poured together while the latter or both are warm, different effects are obtained than if both solutions are cool at the moment of mixing. Where the mixture has been properly made there is scarcely any settling after an hour, while the improperly made mixture has settled more than half.

"Briefly, the best results have been obtained from the use of the Bordeaux mixture made in accordance with the following directions: In a barrel or other suitable vessel place 25 gallons of water. Weigh out 6 pounds of copper sulphate, then tie the same in a piece of coarse gunny sack and suspend it just beneath the surface of the water. By tying the bag to a stick laid across the top of the barrel no further attention will be required. In another vessel slake 4 pounds of lime, using care in order to obtain a smooth paste, free from grit and small lumps. To accomplish this it is best to place the lime in an ordinary water pail and add only a small quantity of water at first, say a quart or a quart and a half. When the lime begins 
to crack and crumble and the water to disappear add another quart or more, exercising care that the lime at no time gets too dry. Toward the last considerable water will be required, but if added carefully and slowly a perfectly smooth paste will be obtained, provided, of course, the lime is of good quality. When the lime is slaked add sufficient water to the paste

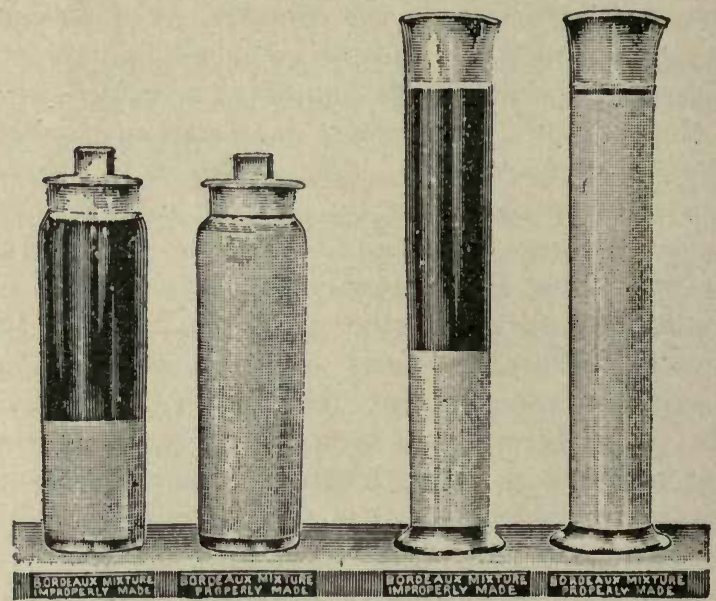

Improperly and Properly Made Bordeaux Mixture

After standing one hour. The properly made mixture has just begun to settle

to bring the whole up to 25 gallons. When the copper sulphate is entirely dissolved and the lime is cool, pour the lime milk and copper sulphate solution slowly together into a barrel holding 50 gallons. The milk of lime should be thoroughly stirred before pouring. The method described insures good mixing, but to complete this work the barrel of liquid should receive a final stirring, for at least three minutes, with a broad wooden paddle. The copper sulphate solution should 
be poured into the lime, rather than the lime into the copper sulphate solution.

"It is now necessary to determine whether the mixture is perfect-that is, if it will be safe to apply it to tender foliage. To accomplish this, two simple tests may be used. First insert the blade of a penknife in the mixture, allowing it to remain there for at least one minute. If metallic copper forms on the blade, or, in other words, if the polished surface of

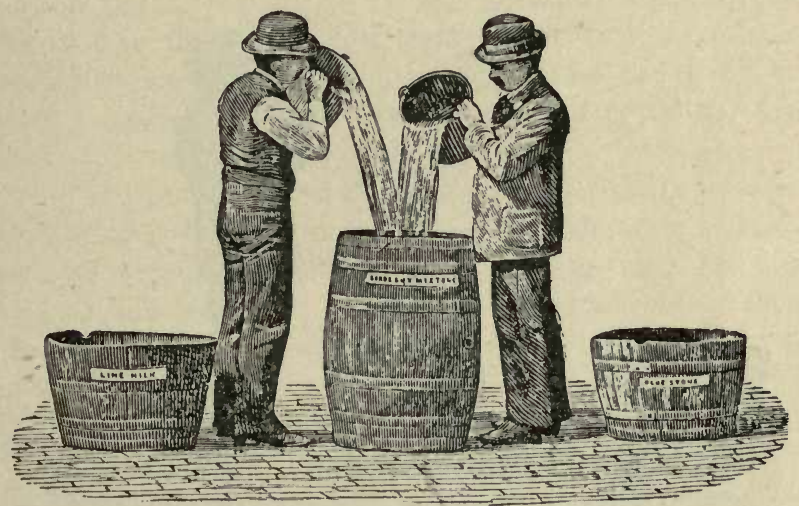

Making Bordeaux Mixture

Pouring together the lime milk and copper sulphate solution

the steel assumes the color of copper plate, the mixture is unsafe and more lime must be added. If, on the other hand, the blade of the knife remains unchanged, it is safe to conclude that the mixture is as perfect as it can be made. As an additional test, however, some of the mixture may be poured into an old plate or saucer, and while held between the eyes and the light the breath should be gently blown upon the liquid for at least half a minute. If the 
mixture is properly made, a thin pellicle, looking like oil on water, will begin to form on the surface of the liquid. If no pellicle forms, more milk of lime should be added.

"The foregoing directions apply to cases where small quantities of the mixture are needed for more or less immediate use. If spraying is to be done upon a large scale, it will be found much more convenient and economical in every way to prepare what are known as stock solutions of both the copper and

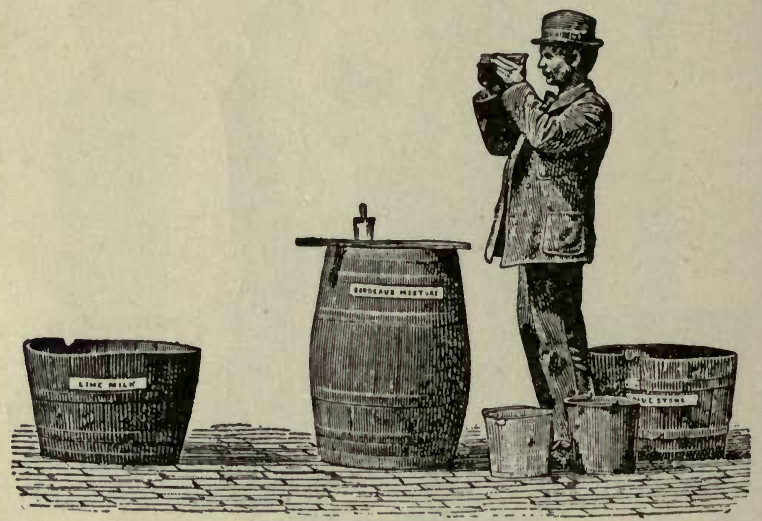

Testing Bordeaux Mixture

The saucer or plate method and the knife method

lime. To prepare a stock solution of copper sulphate, procure a barrel holding 50 gallons. Weigh out 100 pounds of copper sulphate, and after tying it in a sack suspend it so that it will hang as near the top of the barrel as possible. Fill the barrel with water, and in two or three days the copper will be dissolved. Now remove the sack and add enough water to bring the solution again up to the 50-gallon mark, previously made on the barrel. It will be understood, of course, 
that this second adding of water is merely to replace the space previously occupied by the sack and the crystals of copper sulphate. Each gallon of the solution thus made will contain 2 pounds of copper sulphate, and, under all ordinary conditions of temperature, there will be no material recrystallization, so that the stock preparation may be kept indefinitely.

"Stock lime may be prepared. in much the same way as the copper sulphate solution. Procure a barrel holding 50 gallons, making a mark to indicate the 50gallon point. Weigh out Ioo pounds of fresh lime, place it in the barrel and slake it. When slaked, add sufficient water to bring the whole mass up to 50 gallons. Each gallon of this preparation contains, after thorough stirring, 2 pounds of lime.

"When it is desired to make Bordeaux mixture of the 50-gallon formula it is only necessary to measure out 3 gallons of the stock copper solution, and, after thorough stirring, 2 gallons of the stock lime; dilute each to 25 gallons, mix, stir, and test as already described. One test will be sufficient in this case. In other words, it will not be necessary to test each lot of Bordeaux mixture made from the stock preparations, provided the first lot is perfect and no change is made in the quantities of the materials used. Special care should be taken to see that the lime milk is stirred thoroughly each time before applying. As a final precaution it will be well to keep both the stock copper sulphate and the stock lime tightly covered." Care should be taken that there is always some excess of lime.

A special advantage of the Bordeaux mixture is, that arsenicals may be added to it, making a combined insecticide and fungicide. Apparently arsenate of lead is the most satisfactory for this purpose. Added to Bordeaux mixture at the rate of 2 pounds to 50 
gallons it makes very effective insecticide and renders the mixture more adhesive.

Care should be taken not to use the Bordeaux mixture on fruit crops too late in the season. Traces of it remain for some time, notwithstanding numerous rains, and are liable to cause unnecessary suspicions when on marketed fruit. When a fruit crop requires treatment within a month of the time of picking, it is better to substitute some fungicide like carbonate of copper, but it is doubtful if even these combinations should be applied so near the time of the fruit harvest. With nearly, if not quite all our fruit diseases, the treatment slould begin early and not continue too late.

The experience of orchardists indicates that there is danger in using Bordeaux mixture in which there is not an excess of lime, as it causes a russeting of apples somewhat similar to that caused by late frosts in spring.

It sometimes happens that traces of Bordeaux mixture remain upon the fruit, even when a considerable interval elapses between the last application and the ripening of the fruit. Such traces may be easily removed by dipping in a solution made by adding 2 gallons cider vinegar to io gallons water. A good way is to have three tubs, one holding the vinegar mixture and the other two pure water. Then place the grapes or other fruit in wire baskets holding I 5 to 20 pounds, dip them in the vinegar tub for five minutes and then rinse in the two tubs of clear water, afterwards spreading the fruit on frames or shelves, something like those used in the fruit evaporators. Grapes can be treated in this way on a large scale for six cents a hundred pounds.

Carbonate of Copper-This is commonly used in the form of an ammoniacal solution made by dis- 
solving 5 ounces carbonate of copper in 3 pints of ammonia and then adding to a barrel (50 gallons) of water. To prevent loss from evaporation of ammonia, the dissolved carbonate should be added to the water immediately before spraying. It is a simple fungicide, easy to make and apply, and as it is a clear solution, there is no trouble with its clogging nozzles. It has been successfully used to prevent apple scab and various mildews.

A combination of carbonate of copper and carbonate of ammonia recommended by Professor F. D. Chester as superior to the above, is made as follows: "Mix together 3 ounces carbonate of copper and I pound pulverized carbonate of ammonia. Dissolve this mixture in 2 quarts hot water and add to 50 gallons water." A barrel of this mixture costs 12 cents.

Professor Chester also reports good results from copper carbonate prepared as follows: "Thoroughly mix in half a pail of water, I pound of carbonate of copper, to which is added 3 ounces of common glue dissolved in hot water, then dilute to 25 gallons." It would probably be better to dilute to 50 gallons.

Sulphate of Copper-Besides its use in combination with other substances, copper sulphate is often applied to dormant vines and trees early in spring to destroy the winter spores of fungi. For this purpose it is used in a simple solution made by dissolving 2 pounds copper sulphate in 50 gallons water.

Extremely dilute solutions - one part of copper sulphate to I000 parts of water-have been used to advantage in greenhouses to check such diseases as carnation rust.

Potassium Sulphide-Dissolve $1 / 2$ ounce of potassium sulphide (liver of sulphur) in I gallon of hot water. When cold apply in a spray. Used to prevent gooseberry mildew and similar diseases. 
Soda Hyposulphite-Dissolve $1 / 2$ ounce or I ounce soda hyposulphite in Io gallons water. This is especially recommended for gooseberry mildew.

Lye Solution-Professor William B. Alwood recommends a solution of 8 cans of concentrated lye in 50 gallons water for spraying on trees and vines early in spring, before the buds are started, to kill fungus spores. If applied after buds are started much damage might result.

Formaldehyde-Glycerine Mixture-Professor F. D. Chester has lately used with success the following combination in treating pear tree canker: Formaldehyde (40 per cent), I pint; glycerine, 2 pints; water, I7 pints.

Caution-Most of the copper compounds corrode tin and iron. Consequently, in preparing them for use, earthen, wooden or brass vessels should be employed; and in applying them the parts of the pump) which come in contact with the liquicl should be made of brass.

\section{COMBINATIONS OF INSECTICIDES AND FUNGICIDES}

Soon after fungicides came into prominence in this country, the writer called attention ${ }^{\mathrm{I}}$ to the advan tages of so combining them with insecticides that both may be applied at the same time and in the same mixture. Before then, entomologists had worked out remedies for insects, and botanists remedies for plant diseases, but very little had been done in so combining the treatment that the practical man might, so to speak, "kill two birds with one stone." In the article referred to I said: "The necessity of treatment for both classes of injuries is at once apparent to all who have experienced the serious losses due to these agents. Obviously, it is of little use to save a plum crop from IAgricultural Science, r889. 
the curculio, if it is to be destroyed by the fungous disease known as fruit rot; to save raspberries from the slug if they are to be ruined by anthracnose; to save the grape buds from the flea beetle if the berries are to be destroyed by black rot; or to save a pear crop from the ravages of the codling moth and curculio if it is to be distorted and disfigured by the scab; or, to take an example which will strike home to a large proportion of American farmers, it is scarcely worth while to save the potatoes from the Colorado beetle if they are to be ruined by more serious enemies-the potato blights. While the necessity for preventing, so far as possible, injuries of both these classes of organisms is obvious, it is almost equally evident that there will be a great loss of time and labor if each is treated separately. For instance, the farmer who sprays his potatoes with the arsenites two or three times for the beetles, and then goes over them again with solutions of copper sulphate for the blight, would have accomplished the same end in half the time by mixing the copper sulphate and London purple or Paris green in one solution and applying them together. The same is true of the treatment of apples, pears, plums, and, in fact, of a large proportion of the crops liable to injury by both insects and fungi."

Since the above was written a great many experiments along the lines indicated have been made, and we now have a number of satisfactory combinations. Chief among these are the following:

Bordeaux Mixture and Arsenites-Add 4 ounces Paris green to 50 gallons of Bordeaux mixture. This is one of the very best combined insecticides and fungicides. It may be used safely and effectively upon a great variety of crops-such as potatoes for Colorado beetles and blight, apples and pears for insects and scab, and plums for curculio and leaf or fruit diseases. 
The remarks on page 26 concerning late applications of the Bordeaux mixture are equally applicable to this combination.

As already stated on page 25, the arsenate of lead seems even better than Paris green. Add to Bordeaux mixture at the rate of 2 pounds to 50 gallons. Arsenites and Copper Carbonate-The Ohio Experiment Station recommends the following combination: Paris green 2 ounces, carbonate of copper 2 ounces, dissolve in 3 pints of ammonia, add $1 / 2$ pound lime and I barrel of water. It is advised that this be substituted for the arsenite and Bordeaux combination for the later sprayings of apples, pears, plums, etc, so as to avoid the lime coating on the fruit.

Care must be taken in combining the arsenites with other fungicide solutions, as one is liable thus to produce a compound very injurious to foliage. Paris green or London purple added to simple solutions of copper sulphate, or to ammonia compounds without lime, injures foliage vastly more than in simple water mixture.

\section{COST OF SPRAYING MATERIALS}

The average retail and wholesale prices of the various materials used in the spraying mixtures above described are approximately indicated in the following table: Ammonia (22 degrees Baume) .........\$0 07

WHOLESALE

Carbonate of copper (precipitated)

Carbonate of ammonia................

London purple

Paris green

Pyrethrum

Soda hyposulphite

Salsoda

Sulphate of copper (granulated)

White hellebore

Whale-oil soap
35

\section{I2}

06-07

I 5

22-40

06

OI $\mathrm{I} / 4$

05-07

I 2

08-10
RETAIL

Per lb

\$0 25

60

30

IO-I 5

25

40-70

I 5

05

IO-I 5

25

I $5-20$ 
It is quite natural that when most people first learn that the fruit they eat has at some time in its history been sprayed with poison they should object on hygienic grounds. Both in Europe and America the development of the practice of spraying has been accompanied by occasional scares, the last one on this side of the water occurring in September, I88I, when the people of New York, Boston and other eastern cities were agitated by an exaggerated "grape scare," due to the finding of particles of Bordeaux mixture on some of the grapes in the New York market. But when the spraying, either with the insecticides or fungicides now commonly in use, is done with proper reference to the time, methods, and conditions of treatment, there is no danger to the consumer. Both practical experience and chemical tests have demonstrated that apples sprayed early in the season with Paris green or London purple retain none of the poison at the time of ripening. The most recent demonstration of this appears in the last report of the experimental farms of Canada. A peck of Rhode Island Greening apples that had been sprayed twice with Paris green (I pound to 200 gallons of water) were carefully gathered, without rubbing, and tested for arsenic. "The process to which they were submitted is one that affords extremely accurate results, and is considered the most delicate of all for the detection of arsenic. It is capable of revealing the presence of onefifty-thousandth part of a grain of arsenic. If twentythree thousand bushels of apples contained two and a half grains of arsenic, the minimum fatal dose for an adult, the poison could have been detected by this method." Notwithstanding the most careful analysis no traces of poison were found; and in conclusion, the 
chemist states: "I am of the opinion that further experiments of this nature would only serve to corroborate this negative result, and to prove that there are no grounds on which to base a suspicion that our sprayed apples are poisonous. The insoluble character of this poison precluding its assimilation by the apple, if such were possible, the infinitesimal part of Paris green that can remain on the apple, the frequent rains subsequent to the spraying,-all go to substantiate the argument that there is not the slightest danger of poisoning in using sprayed apples."

There is abundant evidence of a similar nature concerning the use of copper salts on grapes. In France, where a large proportion of the grape crop is converted into wine, elaborate investigations have shown that practically none of the copper salts are present in wine from sprayed vineyards. Professor B. Fallot, of the School of Agriculture of Montpellier, in recording the results of one of these investigations, says: "The figures obtained have proved once more that wines, after the grapes have received numerous treatments with large quantities of salts of copper, contain scarcely a trace of this substance, and are entirely harmless."

\section{SPRAYING APPARATUS}

The chief requisites of a good spraying machine are that it be durable, easily worked, not too expensive for the purpose desired, that it throw a fine spray and have a good-sized cylinder, and that the reservoir holding the liquid be large enough for the purpose intended. For fungicides the parts touching the liquid should be made of brass. Although twenty years ago there was scarcely an implement for this purpose upon the market, there are scores of them to-day, and several manufacturers handle them exclusively. They 
may be had in all shapes, styles, and sizes, from the small hand-spray pump to be used with a bucket, and costing a dollar or two, up to the large power machines costing fifty times as much.

There are four general styles of spraying machines upon the market. First, we have the small bucket pumps that serve a useful purpose where only a comparatively small amount of spraying

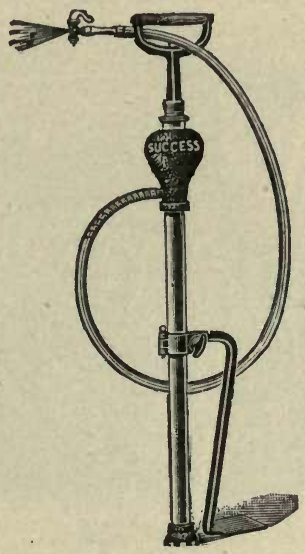

Bucket Pump

is to be done; then come the knapsack sprayers, one of which is illustrated on page 34 , which are especially useful in spraying small vineyards and crops where a horse cannot well be driven; third, we have what may be called the barrel class of sprayers, being good-sized pumps to be attached to barrels mounted in various ways; and, finally, there are the large machines working either by engine or horsepower. For the general purposes of the average farmer or fruit-grower the barrel machines are much the most useful. They are also of moderate cost, ranging from $\$ 8$ to $\$ 16$. They 
can be used in spraying all sorts of crops, and may well be mounted on separate wheels, as in the Chester sprayer shown herewith, or the barrel may be placed in a wagon when in use.

A cheap and efficient homemade spraying cart, designed by Professor F. D. Chester, is illustrated on page 35. According to Professor Chester: "It can be made by any wheelwright, and consists of a truck mounted upon a pair of carriage wheels. Upon this

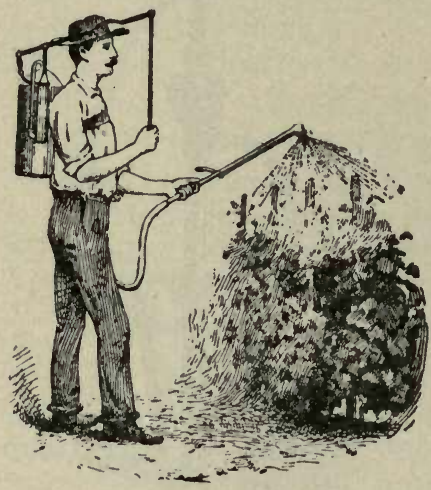

The Knapsack Sprayer

(After Bailey)

is placed a barrel holding 50 gallons, held in place by a strap, which surrounds the same and which is tied in front at either trace. The barrel has a tightfitting cover, firmly strapped in place; upon this is seated the pump. In the large cover is an opening, covered by a lid for filling. Any good force-pump can be used upon the barrel, but it is important that it should be good, and the cheapest are in the long run the dearest. The cheaper iron pumps are excellent at first, but will soon corrode where caustic 
fungicides are used, even with the best of care. All metallic parts that have contact with the fungicides should be of brass. The pump should have a double discharge, one for the spray and another to return a portion of the fluid back to the barrel to keep the same agitated." The pump should have a hose attached, 15 to 20 feet long, with a good spray-nozzle at the end.

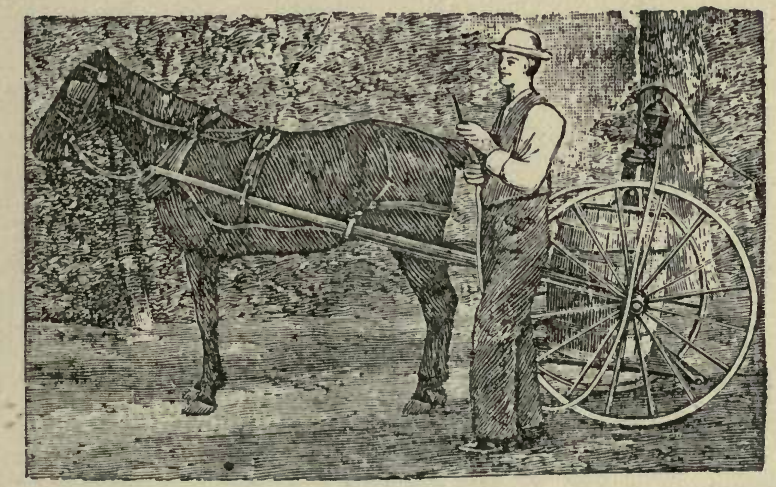

\section{A Handy Outfit}

(After Chester)

For work in the nursery as well as many other places an excellent spraying outfit "can be made by firmly fastening a barrel, end up, on a sled made of heavy durable timber. Mount upon the barrel a good strong, double-acting force-pump provided with twohose attachments, to each end of which fasten 25 feet of $1 / 2$-inch hose. To the end of each hose attach a Vermorel nozzle; then with the necessary gearing for hitching the horse, the outfit is complete. For operating the machine two men and a horse are required. One man does the pumping and attends to the horse, 
while the other walks behind and directs the spray over two rows at a time."I

A good outfit for use in the vineyard, recommended by Professor Bailey, is illustrated below. A barrel with pump is mounted crosswise on the wagon, "and the driver rides and pumps. Another man walks behind and throws the spray up under the vines and on to all the clusters by means of a Ver-

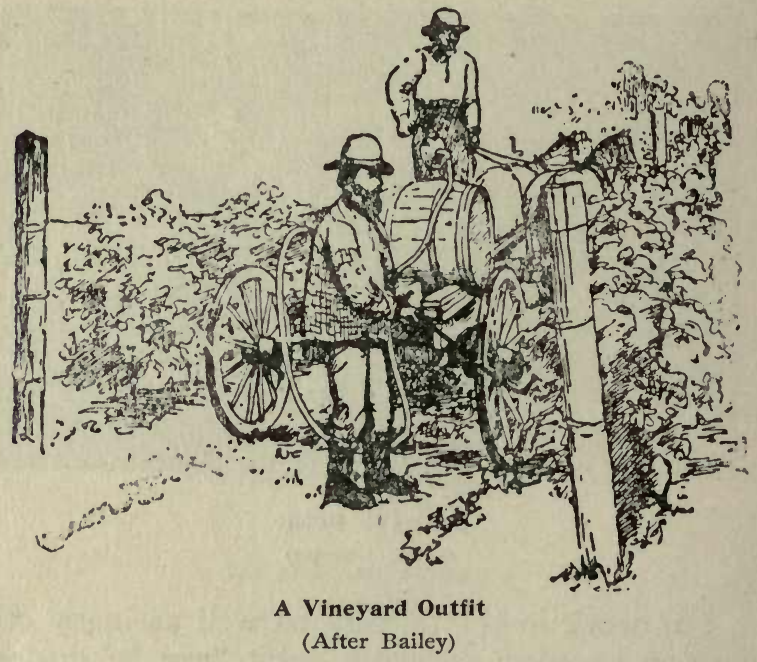

morel nozzle attached to a half-inch gas pipe. This gas pipe has somewhat the form of a slim letter S, the nozzle being attached to one terminal crook, the other crook resting over the man's left arm. The hose is attached near the shoulder. The pipe is so long that the operator is not obliged to stoop, and he can direct the spray in any direction, while the apparatus hangs easily upon the arm. A globe valve 
just below the arm enables the operator to shut off the stream at will."

A handy, homemade, wheelbarrow spraying outfit, gotten up by Professor Bailey, is useful in garden work, especially in spraying small bushes. A Cyclone, Vermorel, or Bordeaux nozzle is used to underspray the foliage.

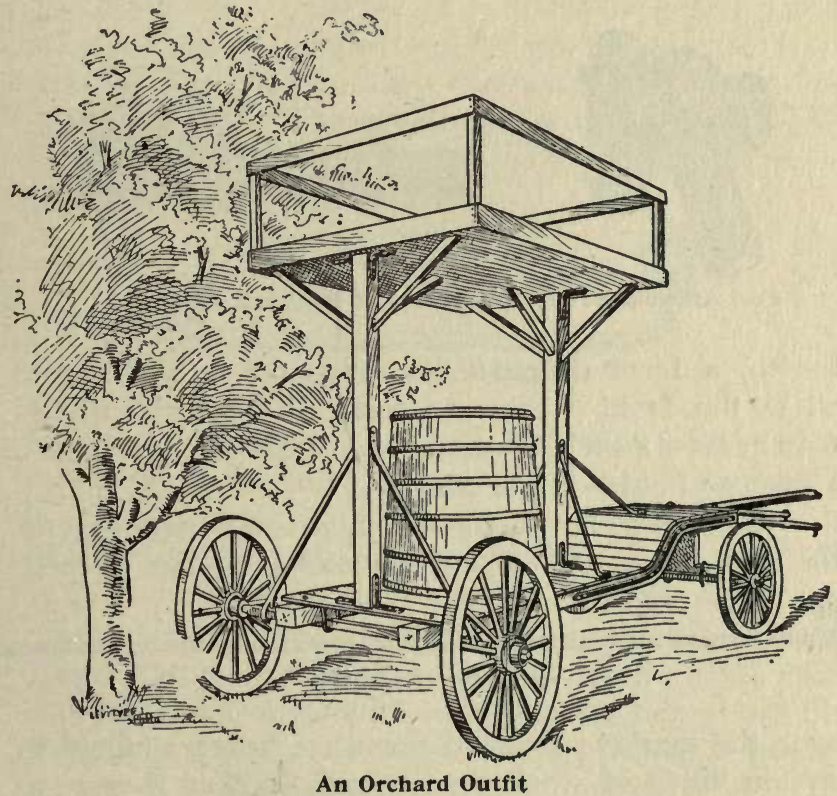

(From Delaware Experiment Station)

A plan for a desirable spraying outfit suggested by the experience of Delaware orchardists is shown above. After much experience $\mathrm{Mr} \mathrm{T}$. S. Derby of Woodside, Delaware, says that the "essentials for economy in time and labor, and for efficiency in 
orchard spraying, are, first, an elevated platform at least 12 feet from the ground, so that the spraying is largely down hill; second, two center uprights to support the platform, instead of four corner uprights, in order to allow the branches to sweep in under the platform, without breaking them or tearing off the fruit spurs; third, a low center of gravity, brought about by setting the bottom of the wagon directly on the axles;

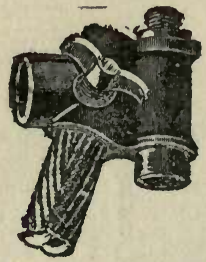

Pole Attachment

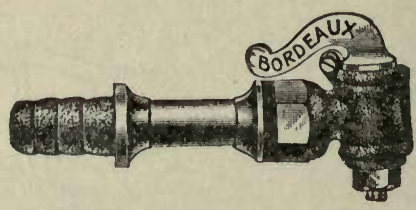

The Bordeaux Nozzle

fourth, a form of extension or goose-neck reach to allow the front wheels to turn short; fifth, whecls with at least 4 -inch tires, and of ordinary height; sixth, a tank to hold 200 gallons."

Nozzles-The nozzle forms an important part of the spraying outfit. There are many varieties of these

Spray Pipe Extension

upon the market; some of them are better adapted to certain kinds of work than others, so that it pays to have several forms on hand where there is a variety of spraying to be done. Some of the best forms are the Vermorel, Bordeaux, Climax, Cyclone, Graduating Spray, Deming, Eureka, and McGowan. For spraying large trees, some method of raising the nozzle nearly to the top is generally necessary. Formerly the commonest way of doing this was to fasten the 
nozzle and hose to a long pole, but a better way is to use a half-inch gas pipe or a brass tube, 12 or 14 feet long, attaching the hose at one end and the nozzle at the other, or one of the bamboo extensions manufactured by some spraying firms. One can also get a handy arrangement for underspraying low bushes, one form of which is shown in the illustration below.

Agitators for Spraying Mixtures-With most poisons held in suspension in water some form of agitator is needed to keep the material from settling to the bottom. "The agitators now in use," writes $\mathrm{Mr}$ A. V. Stubenrauch, "are far from perfect or satis-

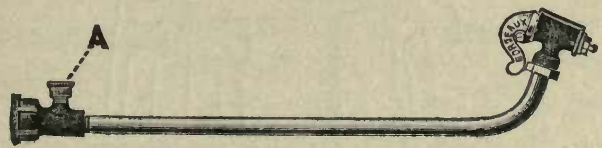

Underspraying Attachment

factory, especially upon long flat tanks; and unless they are continually watched unequal dissemination is likely to result. It is not to be forgotten that the liquid must be kept in motion throughout the tank. It is not alone necessary that a current be created near or around the opening into the pump. For this reason the whirling paddle is perhaps the best, especially if constructed with tilted blades, something like a screw propeller. It is a common practice nowadays to attach a paddle to the pump handle, so that the agitation may be maintained with every stroke of the operator. At first sight this seems to be a good plan, but it is, really, a mistake. If the paddle is a satisfactory one, the labor to keep it going will be far too great when added to that of pumping, and, in consequence, the one will interfere with the other. Besides, 
a violent or quick motion is necessary for thorough agitation, while for pumping, a regular, steady stroke is the best. Therefore it is best not to attempt to couple the two motions.

"Paris green, when "used alone, is, perhaps, the only material which requires continual agitation; and that, in the opinion of the writer, is a serious objection to its use, now that lighter-grained poisons have been found which settle much more slowly and consequently do not need continuous agitation. If we

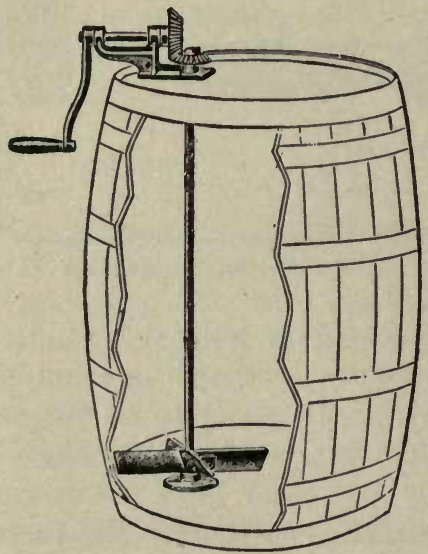

An Agitating Device

omit Paris green from consideration, the liquids now in general use can be sufficiently stirred at short intervals-best while the rig is moving from one tree to another. A separate agitating device is therefore preferable. The operator can do more with the few vigorous turns he is then able to give the agitator than is possible when the motion is dependent upon the pump handle. On large, flat tanks it is practically impossible to keep up a sufficient pressure and 
thorough agitation with the same stroke by hand. Two or three paddles are necessary, depending, of course, upon the length of the tank. These can be connected to a lever on top, a few vigorous strokes of which, at intervals, will suffice to keep up a very thorough dissemination throughout the tank."

Fasten Pump on Side of Barrel-It is much better to fasten the pump on the side of the barrel rather than on the end. In the latter case the pump handle is too high for a man to work to best advantage, and the motion of the wagon is much less likely to keep the liquid sufficiently agitated to prevent the settling of the poison. When the barrel is on the side it is much easier to keep the liquid agitated.

Homemade Strainer - "It is a general precaution that ought to be observed in all spraying operations," writes Mr W. M. Scott, "that everything going into the spray pump barrel should pass through a strainer, and this is particularly necessary in the case of mixtures containing lime. A very good homemade strainer may be made from a strong wooden bucket by boring an auger-hole in the bottom and inserting a six-inch piece of iron piping. A piece of wire gauze, preferably of brass or of copper, is then tacked over the top of the bucket; a most commodious and effective strainer and funnel combined is thus obtained."

Fineness of Spray-In most spraying operations the object is to distribute the poison as widely and evenly as possible over the surface of leaf and fruit. To accomplish this a fine spray is to be desired, fo: the finer the drops of water containing the particles of poison the more general will be the distribution of those particles. Consequently it is generally desirable to use nozzles which break the liquid up into a fine mist that will settle slowly on all parts of the tree or other plant, and when evaporated will leave the fine 
particles of poison rather evenly distributed over all the exposed surfaces.

There are exceptions, however, to this general statement. The one most notable is the case of spraying for the codling moth. Our present knowledge regarding this insect has already been summarized on page 2. As there stated, it seems especially desirable in fighting this pest to be sure to lodge some particles of poison inside the calyx of the young fruit. Apparently this is not so well accomplished by a mistlike spray as by one more coarse. Consequently it is generally recommended that in spraying for the codling moth a spray be used that may be readily directed against the young fruit, forcing good-sized drops to lodge in the calyx so that on evaporation they will leave behind a sufficient residue of poison to insure the destruction of the young worms when they attempt to enter the fruit.

Amount of Spray to Apply-In general, spraying is to be carried simply to a point where foliage and fruit are thoroughly moistened. As soon as leaves begin to drip it is time to stop, for if the application is continued the globules of liquid will run together, leaving on evaporation an excess of material on some parts and not enough on others.

On this phase of the subject, Professor L. H. Bailey's advice is to "spray thoroughly or not at all." And he adds: "I should say that fully half the spraying which I have seen in western New York the last two years is a waste of time and material. - Squirting a few quarts of water at a tree as you hurry past it, is not spraying. A tree is thoroughly and honestly sprayed when it is wet all over, on all the branches and on both sides of all the leaves. An insect or a fungus is not killed until the poison is placed where the pest is. Bugs do not search for 
poison, in order that they may accommodate the orchardist by committing suicide. The one spot which is not sprayed may be the very place where a budworm is getting his dinner. On the other hand there are many fruit-growers who spray with the greatest thoroughness and accuracy, and they are the ones who in the long run will get the fruit."

\section{COST OF SPRAYING}

The cost of spraying depends, of course, upon various conditions, such as the crop sprayed, number of applications, apparatus, and mixture used, etc. It is usually estimated that full-grown orchard trees can be sprayed at a cost of 15 to 25 cents per tree per season, while nursery trees can be treated with Bordeaux mixture the first two seasons for about 25 cents per thousand trees per season.

Professor L. R. Jones, of the Vermont Station, has summarized several seasons' experience of the expense of spraying potatoes as follows: "It is impossible to give a general estimate that will suit all cases, as there are so many varying conditions. The amount of the mixture necessary to cover an acre will vary all the way from 50 to 300 gallons, according to the amount of foliage and the methods of application. Where we have covered an acre with 50 gallons in the middle of July, we have used 100 or I 50 gallons per acre on the same piece in August. Again, in the latter part of August, we have sprayed a poor piece of half-blighted plants with Ioo gallons per acre, and on the same day, on another piece where the ground was covered with a mass of luxuriant leaves, we have found it necessary to use fully 250 gallons per acre. Again, . . the number of applications varies with 
seasons. In I89I, a single application, made August 20 , was sufficient on a piece of late potatoes, while in 1892 three applications were necessary. In general, we should plan for making three applications on all except very early or very late potatoes. These three applications will require from 200 to 500 gallons of the mixture-on the average 400 gallons-used (in Vermont) as follows: Ioo gallons per acre the last of July, I 50 gallons per acre the middle of August, I 50 gallons per acre the last of August. This estimate is for a field planted about May I5 to May 20, and which will yield 200 bushels per acre. In our work it has taken (for three applications) about 2 gallons of mixture per bushel of yield. On early potatoes a fourth application may sometimes be necessary to keep off the early blight, the first application being made the first week in July; in this case it will take about $2 \mathrm{~T} / 2$ gallons per bushel of yield. The mixture costs us about $3 / 4$ cent per gallon, as follows :

5 pounds blue vitriol at 7 cents................ \$0 35

5 pounds lime at $1 / 2$ cent...................... $021 / 2$

Total cost of 50 gallons weak mixture........ \$0 $37^{1 / 2}$

"As most potato growers have to pay a little more than this for blue vitriol, one cent per gallon is about the average cost. The cost of applying also varies much, depending upon luxuriance of growth of plants, and upon apparatus used. In our work, with a barrel pump, three men and one horse have sprayed an acre well in two hours, when water was convenient, or at the rate of five acres per day, making the expense of labor about \$I per acre. Others with similar apparatus have said they could cover ten acres a day." 
The cost of spraying one acre of potatoes three times is summarized thus:

MINIMUM MAXIMUM AVERAGE

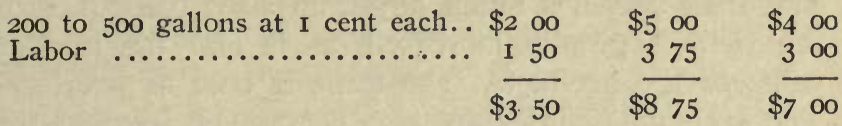

"When we consider our gain of an average of I I3 bushels per acre, worth last fall 80 cents per bushel, or $\$ 90.40$, the profit is great even at the maximum expense."

\section{PROFITS IN SPRAYING}

The profit of spraying has been abundantly demonstrated in nearly all parts of the United States. The benefit derived is usually so marked that the man who tries the method becomes its enthusiastic advocate. In most cases there is not only a greatly increased crop, but the quality of the crop is so improved that it commands a higher price; and in the case of vines, or any plants living more than one year, the plant is kept in a vigorous condition that enables it to store up vitality for the following crop. In Ohio it has been demonstrated that spraying can easily advance the value of the apple crop $\$ 20$ per acre; and in many states it has been shown that spraying is the salvation of the grape-grower. In Vermont it has been demonstrated that the potato crop can be increased more than Ioo bushels per acre by spraying, while in New York it proves equally profitable to the nurseryman. In California, fruit-growers generally have adopted it with very gratifying results. $\mathrm{Mr}$ D. W. Coquillett records an instance where a peargrower actually lost $\$ 2000$ one season because he neglected to spray to prevent codling moth attack. At the Cornell Experiment Station an increase in cash 
value of $\$ \mathrm{I}$ a barrel on sprayed over unsprayed apples was obtained. There are many secondary profits in spraying besides the prevention of actual damage. The fruit becomes much larger in size; consequently the yield is greatly increased, as is also the market value of the product. The same is true of potatoes. The keeping qualities are also very much improvedan item of great practical importance. And according to $\mathrm{Mr} \mathrm{B}$. T. Galloway, the application of Bordeaux mixture has on many plants the effect of a tonic, irrespective of its fungicidal value.

Spraying Is an Insurance-"There are always elements of risk in the growing of fruit," writes Professor L. H. Bailey in a famous bulletin on Spraying Orchards. "The chief of these is frost, a difficulty which will never be completely under control. The second great element of risk is the injury wrought by insects and fungi and the greater part of this injury may be averted by the sprays. Now, it is impossible to foretell by any considerable length of time, if any or all of the difficulties which are liable to harass the fruit-raiser will actually appear. One does not know if his buildings will burn, yet he insures them. We know that in four years out of five, some serious injury of insects or fungi may be confidently expected, and it is the part of wisdom to insure against it. Last year, 1894, was a season of remarkable invasion of apple-scab fungus, and those persons who sprayed their orchards thoroughly had phenomenal results. These experiences, aided by many publications upon the subject, so advertised the value of the sprays that much more spraying was done in the state this year than ever before. But it has so happened, probably because of the dry spring, that comparatively few invasions of enemies have occurred this year; and the sprays have generally given small results. There has 
now arisen, therefore, considerable indifference or even opposition to spraying, and I expect to see much less of it next spring then I saw this spring. If, then, next year should be prolific in insects and diseases, there will be a few orchards here and there which will reward the forethought of the owner, and very many others which will be monuments of the results of neglect. It is a common fault with farmers that they draw their conclusions from the behavior or experiences of each recurring season, and do not consider the aggregate results of a series of years. Every operation should rest upon some fundamental reason or philosophy, rather than upon any single halfunderstood experience.

"A fruit grower wrote me as follows last July: "You are always advising people to spray their orchards. All my neighbors spent much time and money last spring in spraying, but I did not spray and my fruit is just as good as theirs.'

"'I do not doubt your experience,' I replied; 'this has been a dry year and there has been little scab fungus. But you should have insured your orchard against probable loss by spraying it.'

"A few days later, the same correspondent wrote again: "We have had a heavy rain, but it seemed to be poisonous to my potatoes and they are all blackened and wilted. What shall I do?'

"I hope that there was no feeling of scarcasm in my reply: 'I am sorry to hear of your loss, but it is now too late to avert the calamity. Your potatoes were not insured.'

Effect on Size of Fruit-There is a very general agreement that apple trees properly sprayed with a combined fungicide and insecticide yield larger fruit than those not sprayed. A striking instance of this as recorded by Lodeman, is illustrated in the picture 
below: "One hundred average unsprayed apples filled a half-bushel basket evenly full; one hundred average sprayed apples filled a bushel basket evenly full. Thus the bulk of the crop of Maiden Blush was practically doubled."

Spraying has also been found to have a decidedly beneficial effect on the color of the fruit.

Tillage, Fertilizing, Pruning, Spraying-“Spraying has come into use so quickly," writes Professo: L. H. Bailey, "that many people have come to look

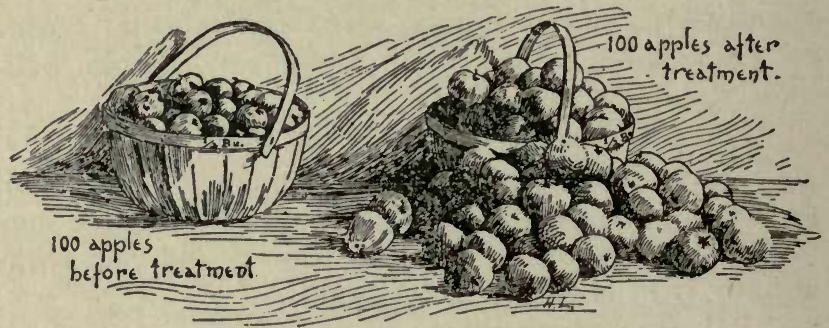

upon it as the means of salvation of our orchards. If spraying is to have the effect of obscuring or depreciating the importance of good cultivation and fertilizing then it might better have never come into being. Trees must grow before they can bear, and this growth depends upon food and proper conditions of soil, more than it does upon the accident of immunity from insects and fungi. There are four fundamental operations upon which all permanent success in most kinds of orchard culture depend, and I think that their importance lies in the order in which I name them-tillage, fertilizing, pruning, spraying. Spraying is the last to be understood, but this fact should not obscure the importance of the other three." 
SPRAYING AND THE WEATHER

According to Professor J. B. Smith, spraying with the arsenites alone "should not be done in the middle of a very hot day, nor, if it can be avoided, on a very hot sultry day. A hot sun on recently sprayed foliage will bring out all the caustic property in the poison applied, and will cause injury. After the moisture has evaporated, and only the thin film of dry poison remains, the sun does not act further on it. On a cool day spray at any hour. On a hot day spray during the early morning or late in the afternoon." These precautions are not necessary, however, when arsenate of lead is used.

Frequent rains often occur during the spraying season, and fruit-growers are sometimes tempted to defer operations till dry weather, but according to the experience of $\mathrm{Mr}$ W. J. Green, it is better, in the case of the Bordeaux mixture at least, "to keep the work going than to wait for dry weather. Of course it would be impracticable to spray during a rain-storm, nor would it be best to spray immediately before, but if the mixture has two or three hours in which to dry before a rain, it will adhere so closely that but little of it will be washed off. Much of it will remain for weeks, even during rainy weather."

\section{SPRAYING TREES IN BLOSSOM}

It is commonly believed that spraying trees in blossom, in case the arsenites are used, endangers the lives of the bees visiting the blossoms. In some regions laws to prevent this have been enacted. Spraying at such times seems unnecessary, and intelligent fruit-growers would not practice it. The bees are essential to the production of fruit, and there is no excuse for destroying them. 


\section{PRUNING TREES}

To use the spraying machine to best advantage the orchard should be carefully and intelligently pruned. On this point Mr E. G. Lodeman writes: ${ }^{1}$ "The pruning and spraying of fruit trees are two subjects which are closely related. This is especially true in the case of the apple. Moisture is favorable to the development of the apple-scab fungus. When the tops of trees consist of a tangled mass of large and small branches, they are much longer in dying out than when they are open. Not only is a shelter given to fungi, but their growth is encouraged, and each tree becomes the distributing center of some disease. The mischief is also aggravated by the fact that it is as difficult for any remedies to gain an entrance as it is for the light and air. It is impossible to spray such trees to advantage, even granting that the fruit borne by them would warrant the expense. The head of the tree should be open, so that all parts may be reached easily with the spray." The presence of these useless branches also requires the application of much more of the spraying compound than is otherwise necessary, thus involving a decided waste of time and material. By all means prune your orchards properly before you spray them.

In planting new orchards, the trees should be set so far apart that when full-grown they may easily be sprayed. They should not be nearer together than 40 feet each way.

\section{A SPRAYING CALENDAR}

Dr William C. Sturgis of the Connecticut Experiment Station has published the following provisional calendar of the spraying operations for the year. As 
the author says, it is, of course, impossible to give accurate dates for various sprayings, on account of the difference in latitudes and seasons. But the dates are approximate, and the calendar has a decided value.

January and February-But little can be done during these midwinter months in the way of spraying, though a great deal by way of preparation. If it has not already been done at the proper time, cut out and burn the black knot of plum and cherry now, and destroy all neighboring wild cherry trees which are knotty. In the latter part of February do all necessary trimming of vines and fruit trees, unless this has been done in the autumn. Where anthracnose has previously attacked grapevines, raspberries, or blackberries, prune severely, cut out every trace of diseased wood or cane and burn it. . . . In open winters, February is none too early to go over the orchard carefully and collect and burn all leaves and fruit from diseased trees, such as mummified cherries, plums, and peaches, scabby or rotted pears and quinces, and all blighted leaves. Remember that on the first warm day the air will be full of the germs of plant diseases from these fruits and leaves, if they are not destroyed. Do not use them for bedding or mulch, and do not throw them into the pig-pen.

March-The middle or end of this month will see everything ready for winter treatment (copper sulphate, I pound to 25 gallons of water). Select a warm day, or, if possible, several days of warm, melting weather. In some seasons winter treatment can hardly be made before April. This treatment is especially good for diseases of pear and quince, for anthracnose and for the black rot of grapes. Where the latter has occurred the previous year, ploughing between the rows, in order to cover up diseased berries, 
will be found of great advantage. This is the time also for treatment for San Jose scale.

April-Put all spraying apparatus in thorough order. Clean and rinse pumps, oil all bearings, see that the valves work well, and test the tubing for leaks. If the winter treatment has been deferred until this month, see that it is finished before the middle of the month.

May-This is usually the flowering month for vines and fruit trees, and the first application of Bordeaux mixture or other fungicide should immediately precede the opening of the flowers. Use your own judgment. Apples are generally in bloom by the second week in May; quinces, pears, and grapes usually not until somewhat later. The importance of these early treatments can hardly be overestimated. Watch to see when the petals begin to fall; and make a second application within a few days of that date.

June-The first part of June usually marks the fall of the flowers of most fruit trees. Never spray while trees and vines are in full bloom. Make the second application as soon as the petals have fallen. This will be late in May or early in June, for apples; a week or ten days later for other fruit trees and grapes. Make the June treatment thorough.

A good general rule to follow after the second spraying is to let each additional treatment be made from ten days to three weeks after the preceding one; the shorter interval if there are heavy washing rains; the longer if the weather is comparatively dry.

July-This month will close the treatment for most diseases. To avoid the spotting of grapes by the Bordeaux mixture, the two applications during the latter part of this month should consist of the ammoniacal solution of copper carbonate. Early in the month 
spray for black rot of quinces, and continue treatment every two weeks until the last of August.

August-The spraying season closes this month. For leaf-blight of strawberries, mow the leaves late in July or early in August, and after allowing them to dry where they lie, set fire to them and burn the bed over. Thoroughly clean and oil all spraying apparatus, and see that it is carefully stored.

September, October, and November-The months of harvest. When picking fruit let one or two boys follow and clean the trees of all diseased and mummified fruit, collecting it in baskets to burn. At the same time gather and burn, as far as possible, all diseased fruit which has fallen. In November clean the orchard thoroughly of fallen leaves, especially if disease has been prevalent, and burn them. Better to destroy them now than in the spring, when the fungus fruit will have come to maturity in and on the leaves.

December - The black knot fungus matures during December and January; attack it early in the former month. Use the pruning knife unsparingly, cutting out two or three inches above and below each knot. Burn every knot and paint the wound over at once.

\section{SPRAYING PRECAUTIONS}

The man who uses a spraying machine assumes a responsibility which he has no right to neglect. Some precautions to be taken are indicated below.

Always label all poisonous preparations in plain large lettcrs, POISON. Never leave poisonous compounds within the reach of children, ignorant persons, or domestic animals. Never spray trees in blossom.

In using a compound with which you have had no cxperience, and which is reported as at all liable to injure foliage, use only weak mixtures, and, if possible, try its effects first on a small scale. 
Oron a spraying pump yourself. If you have to wait to borrow your neighbor's, the chances are that you will begin too late.

Spray in time; begin carly; do not wait until the horse is stolen and then try to lock the door by spraying.

Do not spray indiscriminately, anything and everything. Adapt your means to your ends. Study the enemies of your crops and then fight them intelligently.

Of two mixtures equally effective, choose the one least liable to injure foliage. Take the trouble to add a little lime to Paris green or London purple mixtures.

Never spray ripening fruit.

Always remember that spraying requires the exercise of skill, judgment and knowledge, to get the best results. 


\section{PART I}

SPRAYING THE LARGER FRUITS 


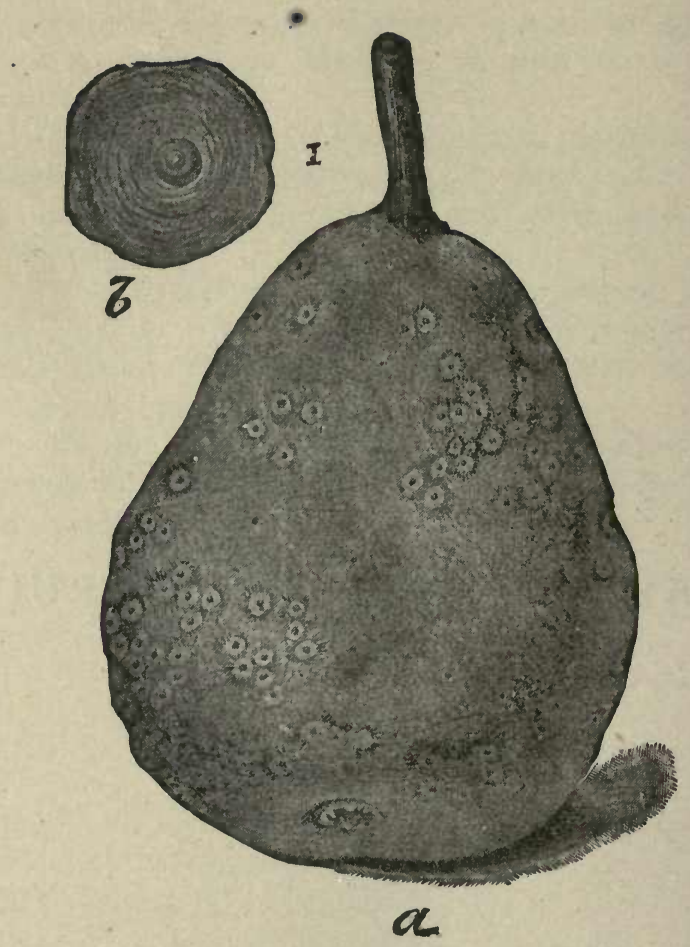

San Jose Scale

$a$, pear, moderately infested-natural size; $b$, female scale-enlarged (After How ard) 


\section{Spraying the Larger Fruits}

\section{THE APPLE}

INSECT ENEMIES OF THE TRUNK AND BRANCHES

The most destructive insect that comes under this heading is the San Jose Scale or Pernicious Scale. which has attracted so much attention during recent years. This pest is now very generally distributed over the United States and is yearly doing an enormous amount of damage. It can at cnce be distinguished from the Oyster-shell Bark-louse by its circular scale, as shown at $b$ in the figure on the opposite page. This insect infests practically all kinds of deciduous trees, and if unmolested it is liable to kill them. It multiplies with marvelous rapidity, especially through the long seasons of the southern states.

Dr L. O. Howard describes the San José scale as "perfectly round, or at most very slightly elongated or irregular. It is flat, pressed close to the bark, resembles the bark of the twigs in color, and when fully grown is about one-eighth of an inch in diameter. At or near the middle of each scale is a small, round, slightly elongated black point; or this point may sometimes appear yellowish. When occurring upon the bark of the twigs or leaves and in large numbers, the scales lie close to each other, frequently overlapping, and are at such times difficult to distinguish without a magnifying glass. The general appearance which they present is of a grayish, very slightly roughened 
scurfy deposit. The natural rich reddish color of the limbs of the peach and apple is quite obscured when these trees are thickly infested, and they have then every appearance of being coated with lime or ashes. When the scales are crushed by scraping, a yellowish oily liquid will appear, resulting from the crushing of the soft yellow insects beneath the scales, and this

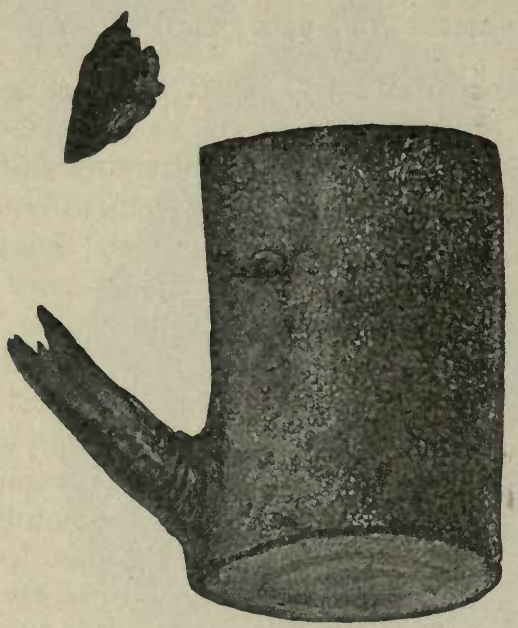

San Jose Scale

Apple branch, with scales in situ-natural size; enlarged scales above, at left (After Howard)

will at once indicate to one who is not familiar with their appearance the existence of healthy living scales on the trees."

The young scale lice come out from beneath the female scales, in spring, soon after the unfolding of the leaves. They are minute yellowish creatures which crawl about over the bark a short time, and finally fasten themselves to it, generally on the new 
growth, where each secretes a scale and develops. Some of them wander to the leaves and fruit, where they mature. The infested leaves turn brown, but do not have a tendency to fall as a result of the damage.

This pest is most likely to be introduced into new localities upon nursery stock imported from infested regions. This is believed to be the way in which it was first brought to the eastern states. It is also likely to be carried upon fruit sent to market. In a given locality the insects are most likely to be carried from tree to tree and orchard to orchard by the young lice crawling upon insects and birds and then crawling off after they have lit upon other trees. They may also be blown about by the wind.

Remedies-The two remedies now generally employed in the eastern states are kerosene or crude petroleum and the lime, salt and sulphur wash. The latter has been rapidly gaining friends of late and by many authorities is considered the most effective remedy. Both of these insecticides are applied in winter or early spring-before the leaves appear. The application must be thorough-covering all parts of the tree.

A piece of bark covered with the scales of the Oyster-SHell BARK-Louse is represented on page 60. If one of these scales be raised early in the spring, there will be found beneath it a mass of yellowish or whitish eggs, which hatch about the middle of May into small lice, that appear as mere specks to the naked eye. These move about over the bark a few days, when they fix themselves upon it, inserting their tiny beaks far enough to reach the sap. Here they continue to increase in size, and by the end of the season have secreted scaly coverings. 
Remedies-During the winter and early spring scrape the trunk and larger branches with a hoe, and then thoroughly scrub with a scrub-brush dipped in a solution made by adding one part of crude carbolic acid to seven parts of a solution made by dissolving

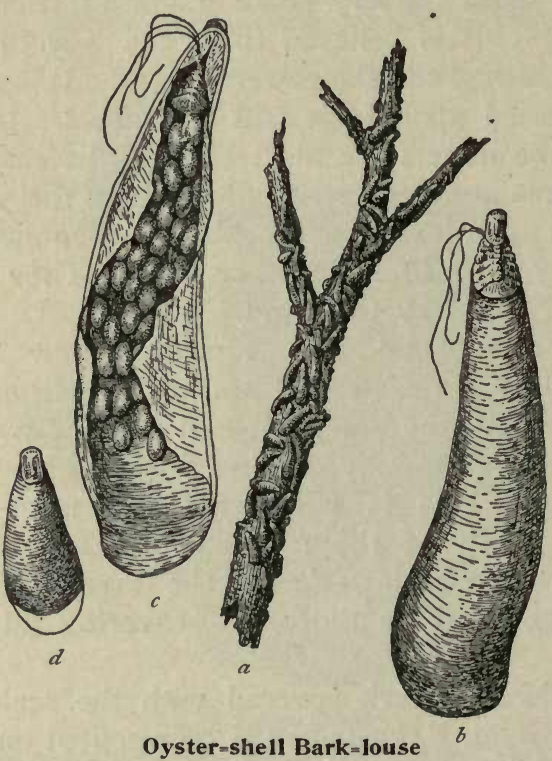

$a$, scales on apple twig; $b$, female scale, back view, magnified; $c$, female scale and eggs, under-side, magnified; $d$, male scale, magnified

one quart of soft soap, or one-fourth of a pound of hard soap, in two quarts of boiling water. Then in May or June, soon after the young lice have hatched, spray with kerosene emulsion. When the lice are young they are very readily destroyed by this substance. The lime, salt and sulphur wash appears to be effective also against this pest. 

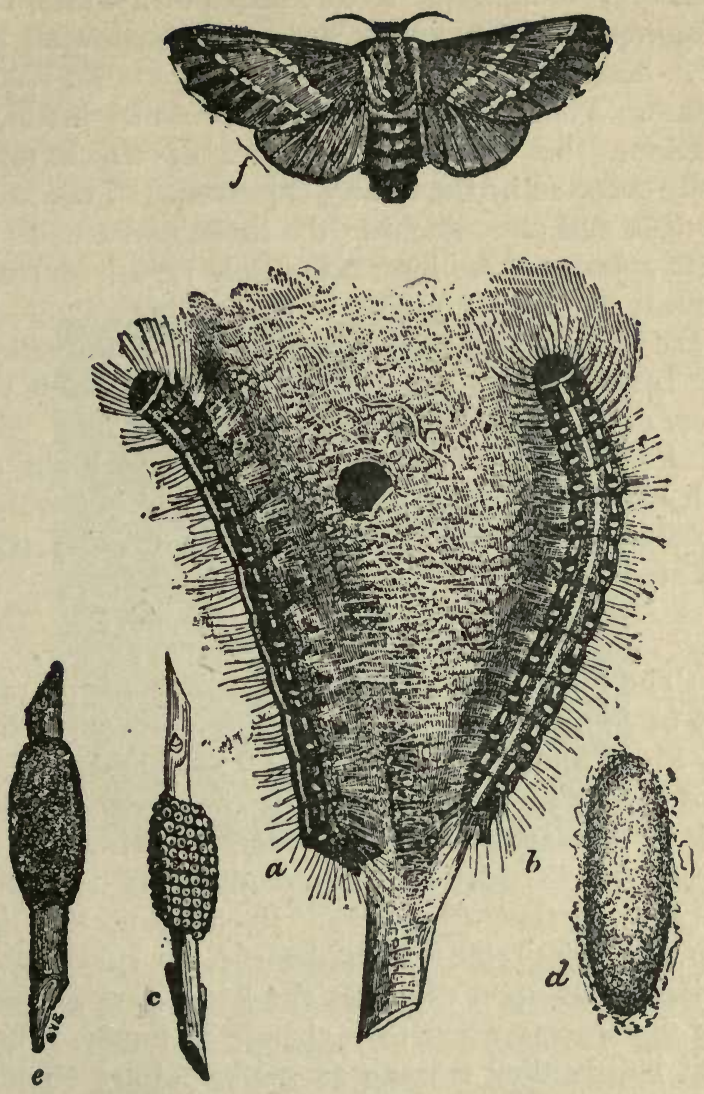

Transformations of the Tent Caterpillar

(After Riley) 
There are frequently found on the limbs and trunks of young apple trees, masses of a white, woolly substance, beneath which are small, yellowish plantlice. These are the inseçts known as the Woolly Apris. There are two forms of the insect, one attacking the roots, the presence of which may be easily detected by the knotty appearance of the infested rootlets, and one attacking the limbs and trunk. Like other aphides, these insects multiply rapidly during the summer months, by giving birth to living young. They injure the tree by sucking out its sap through their tiny beaks. They are especially liable to infest young trees, or those which are unhealthy.

Remedies-When on the trunk and limbs spray with kerosene emulsion; on roots apply hot water, or kerosene emulsion, or dig in refuse tobacco powder and stems.

\section{INSECT ENEMIES OF THE FRUIT}

The insects affecting the fruit of the apple, which may be fought by spraying, are the Codling Moth, and the Plum and Apple Curculios. Of these, the CoDLing Moth or Apple Worm is the most destructive, and is, in fact, the most generally injurious apple insect. Its life-history has already been described in the Introduction (page 2). In fighting this insect it is often desirable to supplement the spraying with burlap bands upon the trees the latter part of June to trap the worms when they change to pupae, crushing them before they emerge as moths. Care should be taken also to prevent the egress of moths in spring from rooms in which apples have been stored.

In Oregon it seems to be necessary to spray late for the second brood of worms. But if the burlap bands were used persistently this probably could be avoided. 
The Apple Curculio is a small, dull brown, hardshelled beetle, with a long snout and four peculiar warts on its back. The beetles drill holes in young apples, both for food and the deposition of eggs. The latter are laid at the bottom of the cavity, and soon hatch into grubs or larvae that feed upon the pulp of the fruit. They usually penetrate to the core, where they continue feeding four or five weeks, when they become full grown and pupate within the cavity of the

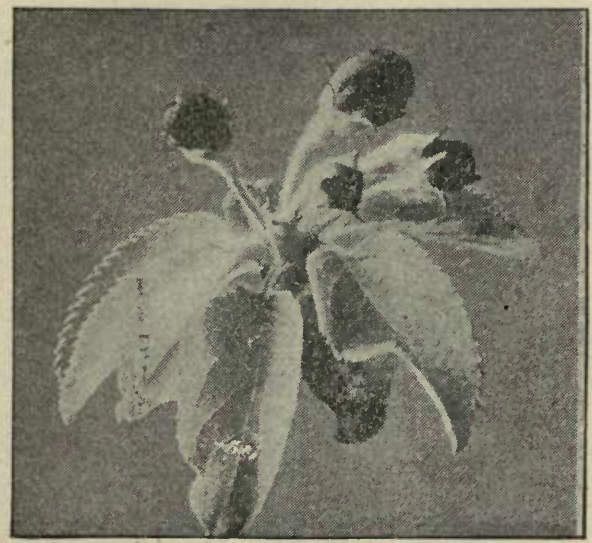

\section{Apple Buds}

apple. Two or three weeks later they emerge as perfect beetles, which pass the winter under boards or rubbish. The fruit attacked by this pest becomes dwarfed, gnarly and ill-shapen. Apples are often seriously injured by the PLUm Curculio, which works in a way similar to the apple curculio. Its life-history is described on page 4 .

Remedies-The injuries of these two insects, as well as of several others of minor importance, may be prevented to a considerable extent by spraying with the 
arsenical poisons. Spray first as soon as the blossoms have all fallen, and again about ten days later. In localities where the curculios are very injurious, one or two more sprayings may often be made to advantage at intervals of two weeks, especially on late varieties. It will pay to add lime to the spraying solution (see page IO), unless the arsenite is combined with Bordeaux mixture, which has the same saving effect. The addition of lime is not necessary, however, if arsenate of lead is used.

The poison is supposed to take effect in the case of the codling moth by destroying the young larvae just after hatching and probably while attempting to nibble through the skin; while with the curculios it takes effect upon the parent beetles, thus preventing the deposition of eggs.

\section{INSECT ENEMIES OF THE FOLIAGE}

A large variety of insects feed upon apple foliage. Many of them are caterpillars of moths, and are easily destroyed by spraying. Among the most injurious of these are the CANKER WORMS, of which we have two distinct species-the FALL CANKER WORM and the Spring Canker Worm. The different stages of the former pest are illustrated on page 5 , where a resume of its life-history will be found. When an orchard is infested by canker-worms it is very desirable to spray once before the blossoms open. The insects begin hatching early in the season; if trees are not sprayed until after the blossoms fall considerable damage will be done before the worms are killed. One spraying just before the blossom buds open will be of much service. Another should be given as soon as the blossoms fall; and if the canker-worms are very numerous a third-a week or ten days after the second-will be desirable. 
The Tent Caterpillar is another insect that is often extremely destructive to apple foliage. This is the creature that constructs the silken tent-like nests so often seen in spring on the branching limbs of apple and wild cherry trees. Its life-history is as follows: The eggs are deposited during July in compact masses of 200 or 300 each upon the twigs $(e, c)$, and are

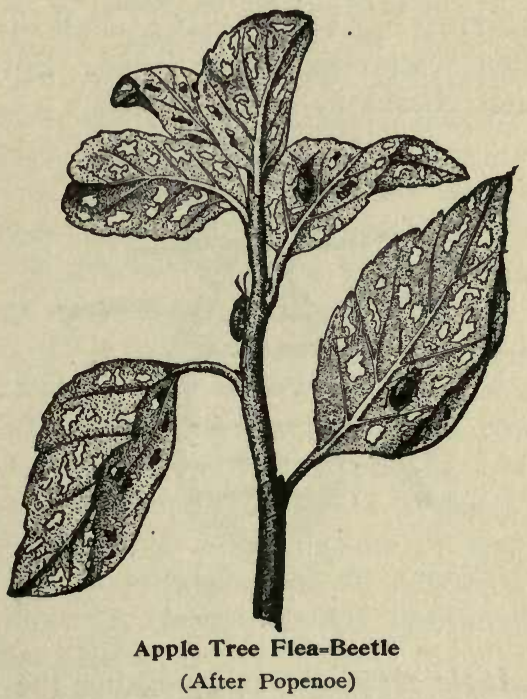

covered with varnish (e). The following spring they hatch into caterpillars that feed upon the tender foliage and make a silken tent in a fork of the twigs. They become full grown in about six weeks $(a, b)$. They then leave the tree and crawl about in search of a suitable shelter to pupate in. Having found thisbeneath a board, or in the cracks of a fence-they spin an oval, silken cocoon (d), yellow when completed, within which they change to pupae. In two or three 
weeks the reddish-brown moths come forth. These deposit the clusters of eggs, after which they soon die. There are a number of other caterpillars which feed upon apple foliage, notably several species of Leaf-rollers, the Yellow-Necked Caterpillar, the LEAF-CRUMPLER, the LEAF-SKELETONIZER, etc, all of which are treated of in the author's Insects and Insecticides, and all of which may be destroyed by spraying. The Apple-tree Flea-beetle is a small shining beetle that is often destructive in the West. Spraying with the arsenites checks it.

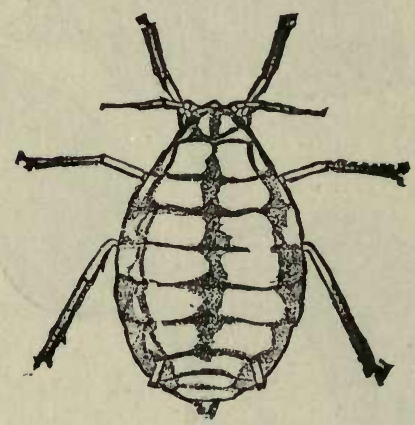

Apple Aphis

Much magnified

The Apple Aphis-During spring the leaves and tender twigs of apple are often covered with small green lice or aphides. These are the insects known as the Apple Aphis. They injure the trees by sucking the sap through their tiny beaks. The lice hatch from eggs in spring as soon as the leaf-buds begin to expand, and they increase with marvelous rapidity, so that almost as fast as the leaves develop there are colonies of the plant-lice to occupy them. They breed on apple until July, when they largely leave the trees, and migrate apparently to various grasses. Here they 
continue breeding until autumn, when they return to apple, and the winged females establish colonies of the wingless, egg-laying form upon the leaves. The small, oval eggs are now laid on the twigs and buds, and the cycle for the year is complete.

Remedy-On large trees it is seldom necessary to apply remedies for this insect. Spray with tobacco decoction or kerosene emulsion as soon in spring as the eggs hatch-usually before the leaves expand.

The opening buds of apples are sometimes seriously injured by the larva of the EYE-SPOTTED BUDмотн. This is a small cylindrical worm, threefourths of an inch long, which lives in a rude case made by fastening particles of dead leaves together with silk. It attacks the buds, blossoms, and newlyformed fruit as well as the leaves, and becomes fullgrown early in June. The larvae then pupate within their cases, and in a few weeks emerge as small moths, with two little eye-spots on each of the front wings.

Remedies-This is a difficult pest to contend with, and the most promising remedy is to spray early, as the buds are opening, with arsenate of lead or other arsenical or a combination of an arsenical and the Bordeaux mixture, continuing the treatment later as recommended below.

\section{FUNGUS ENEMIES}

Probably no fungous disease of fruit is more familiar to the general public than the Apple Scab, or, as it is occasionally called, the BLAck Sрот. This is due to a fungus which produces the well-known scabby spots upon the fruit, and also attacks the leaves and green shoots. It first appears on the leaves in the shape of smoky, greenish spots, more or less circular in outline. These gradually enlarge, and frequently several of them run together, so as to form good-sized 
blotches; and as they grow older their color darkens, finally becoming almost black. The upper surface of the leaf is generally the one infested. Immense numbers of spores are produced on these blackened spots of the leaf and fruit, forming most abundantly during cool, wet weather. By means of these spores the fungus reproduces itself; they are carried from leaf to leaf and fruit to fruit by wind and rain, and germinating, start the disease in a new situation. The spores pass the winter on stored fruit, branches, fallen leaves, etc, and in spring start the disease again. It is especially destructive in wet seasons.

A disease called PrNk Rot often attacks scabby apples in storage, the fungus of the pink rot getting access to the pulp of the fruit through the cracks in the skin caused by the scab.

Remedies-In spring, just before blossoms open, spray thoroughly with the Bordeaux mixture, repeat the application after the blossoms have fallen, adding arsenate of lead at the rate of 2 pounds to 50 gallons, in order to destroy the codling moth larvae, and other insects, as well as the scab; ten days after this last application, spray again with the combination of Bordeaux mixture and an arsenical. Do not apply the Bordeaux mixture late in the season; it is liable to injure the skin of the apple by giving it a rough and russet appearance. Fruit sprayed in this way is much larger and finer than that not sprayed.

In southerly latitudes, orchardists are greatly troubled by another fungous disease, the APPLE Rot, which attacks the maturing fruit, rotting it and causing serious losses. Experiments in Kentucky by Professor Garman have shown that this disease may be prevented by treatment with Bordeaux mixture similar to that indicated above. 


\section{THE PLU'M}

\section{INSECT ENEMIES OF THE FRUIT}

The Plum Curculio is by far the worst insect foe of the plum. It is the cause of most of the common worminess and premature dropping of the fruit. An account of its life-history will be found on page 4 .

Remedies-The evidence in hand indicates that spraying with the arsenites is an effective way to fight this pest, especially in orchards of considerable size. This remedy acts by destroying the adult beetles rather than the larvae. The trees should be sprayed three or four times, at intervals of ten days or two weeks, beginning, as soon as the blossoms have fallen, with arsenate of lead in good strength or with Paris green mixed with water in the proportion of 3 ounces to 40 to 50 gallons. These sprayings will also destroy certain other insects affecting the fruit, although it is generally supposed that they will not kill the PLUM Gouger - an insect related to the curculios-which is very injurious in some of the western states. The best way will probably be to combine arsenate of lead with the Bordeaux mixture as described under the next heading, and so fight both the insect and fungus pests at the same time. This is especially desirable because some of the arsenites alone are liable to injure the foliage when a series of applications are made, though this is not true of the lead arsenate.

During recent years trouble has been experienced in some localities because of the FRUIT-BARK BORER, an insect that burrows channels beneath the bark. There is some evidence to show that spraying the trunks and larger branches with the combination of 
Bordeaux mixture and Paris green will prevent such injury. The first application should be made early in the spring, and others follow at occasional intervals until July.

\section{FUNGUS ENEMIES}

The Brown Rot of Stone-fruits is the most serious enemy under this heading. Fruit affected by this disease turns brown and rots, and generally develops on the skin a velvety or powdery brown coating. This coating consists of a great number of minute spores fastened together, end to end. If one of these velvety masses be shaken over a glass slide and the slide then put under a microscope, it will be seen that a great many of the spores have separated and fallen off. When one of these spores lights upon a green plum, peach, or cherry, and a drop of water happens to form over it, it sends out a germinating tube which penetrates the skin of the fruit, and once inside develops a mass of mycelium, disorganizing the tissues and causing rot. Then this mycelium develops a new mass of spores, and thus the fungus propagates itself. After the development of the spores, the plums or peaches dry up and hang on the limbs until the following season, when they start the disease again. Even the blossoms are often attacked.

The first step towards preventing this disease is to pick off and burn the dry and mummied plums that hang on the trees over winter. These carry the disease through cold weather and start it again in the spring. The fruit rots worst when it hangs on the tree until fully ripe. In commercial orchards it should be picked before it is ripe. Rotting plums during the ripening period should also be promptly removed.

During summer the leaves of plums and cherries are often injured by the Plum Leaf-blight or 
Shot-hole Fungus, which first appears in the shape of small dark purple spots scattered over the leaf. These spots soon become brown, and the leaf tissue

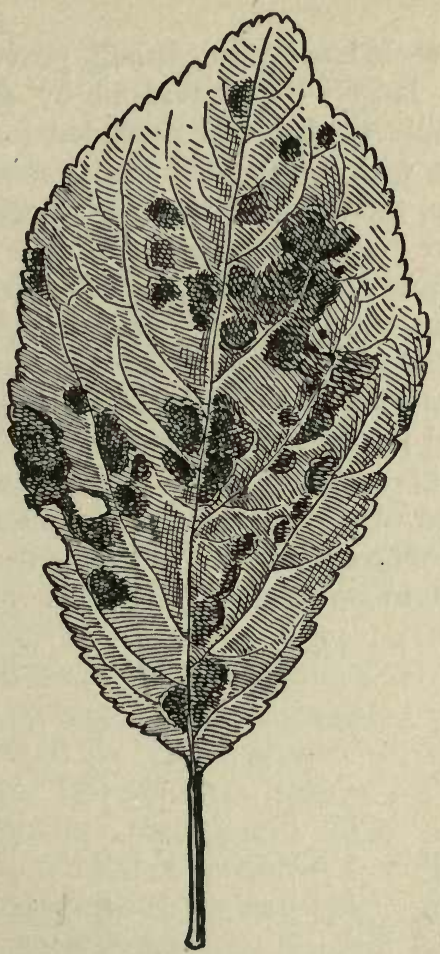

Diseased Plum Leaf

(After Bailey)

composing them is dead. This dead tissue generally drops out of the leaf in course of a few weeks, leaving circular holes resembling shot holes. A microscopic examination of the under surface of these spots gen- 
erally reveals one or more blackish points consisting of the fruiting spores of the fungus. It is by means of these that it passes the winter, and propagates itself. The affected leaves often turn yellow and fall off.

Remedies-It has been definitely proven that these diseases may largely be prevented by spraying. A treatment similar to that recommended for apple-scab, one spraying with dilute Bordeaux mixture before blossoms open, then two or three sprayings. with Bordeaux mixture having an excess of lime and one of the arsenites after the fruit forms, is the most promising treatment for both insect and fungus pests. It may be necessary to make one or two late sprayings with a carbonate of copper solution in case rot sets in. The mummied plums should be picked off and burned in the winter; and an early spring spraying with simple solution of copper sulphate, applied before the buds swell, is very beneficial. The Japanese plums are very sensitive to sprays, but they are less liable to these diseases. 


\section{THE PEACH}

\section{INSECT ENEMIES}

The San Jose Scale is one of the most destructive enemies of the peach. Winter spraying with the lime, salt and sulphur wash seems to be the most effective remedy.

The Plum Curculio, whose life-history has already been treated of on page 4, breeds in peaches, as well as in plums, cherries, apples, and other fruits. It is especially liable to injure peaches when there is a failure of the apple crop. Some of the largest growers in America jar their peach trees systematically to catch the curculios. Apparently it is still a question whether the insect could be successfully fought by spraying with arsenate of lead. Peach foliage is especially liable to injury by some of the arsenites.

Peach foliage is occasionally attacked by the REDLEGGED FLEA-BEETLE, a small jumping beetle which may be destroyed by spraying with arsenate of lead.

There are two distinct species of aphides or plant-lice attacking the peach. One is called the Peach Aphis, and the other the Black Peach Aphis. The latter infests the roots and twigs as well as the leaves. Both species are soft, blackish little creatures that crowd together on the foliage and twigs. During the summer they reproduce viviparously. Spraying with fish-oil soap, tobacco decoction, or kerosene emulsion, as early as possible after the pests appear in spring, is the best remedy. The time to reach them easiest is when the buds are swelling and the newly hatched lice are on the bare twigs. 


\section{FUNGUS ENEMIES}

It often happens that in spring, soon after the leaves begin to expand, the foliage of peach trees becomes curled and misshapen. The leaves are usually

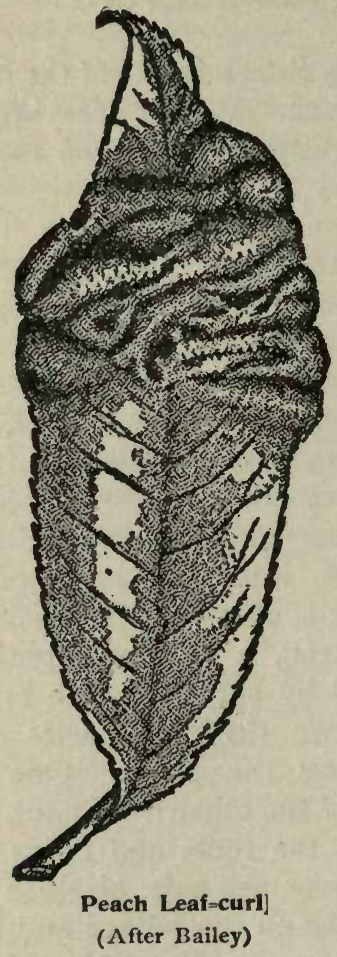

thickened and discolored, and fall off in a short time. All the branches may be attacked, or the injury may be confined to only a part of the tree. When the disease is severe the young fruits fall off, and the crop for the year is destroyed. The defoliated trees soon 
push out a new set of leaves, but too late to repair the damage done to the fruit crop.

This Peach Leaf-CuRL is most injurious during wet springs. It often ruins the peach crop over large areas. It is uncertain in its attacks, some seasons doing much damage and others comparatively little.

Remedies-It has been repeatedly demonstrated that a single spraying with Bordeaux mixture in early spring will prevent this disease. All trees should be sprayed with a good strength of Bordeaux mixture at least two weeks before the blossoms open: The application should be so thorough as to cover the branches and buds all over the tree. In all cases the nozzle should be held below rather than above the part of the tree being treated and the spray thus directed upward will in falling wet the upper side of the horizontal branches.

The Brown Rot, already discussed as a plum disease (page 70), is often extremely destructive to peaches. It sometimes attacks the trees early in spring, causing an injury to the twigs and blossoms called blight, and again infests the fruit up to the time of ripening, and even after it is gathered.

The most promising remedial measures are those of picking off all the dry peaches hanging on the tree during winter, and then spraying early in the spring before the buds begin to swell, with a dilute Bordeaux mixture, not more than 2 pounds copper sulphate to 50 gallons water, which may often be repeated to advantage just before the blossoms open. Then after the blossom petals have fallen spray twice with an interval of two weeks between. Peach foliage is very casily injured, and care should be taken in spraying it. Two or three pounds more lime should be used in the Bordeaux mixture than usual, to avoid injury to the foliage. 


\section{THE PEAR}

\section{INSECT ENEMIES OF THE FRUIT}

The fruit of the pear is attacked by both the CoDLing Moth and the Plum Curculio. The injury of the latter causes it to be knotty, gnarly, and one-sided, ruining it for market purposes. Fortunately the injuries of both may largely be prevented by two or three sprayings with arsenate of lead mixed with water at the rate of $I$ pound to 50 gallons. The first application should be made as soon as the petals have fallen, and the others at intervals of ten days or two weeks.

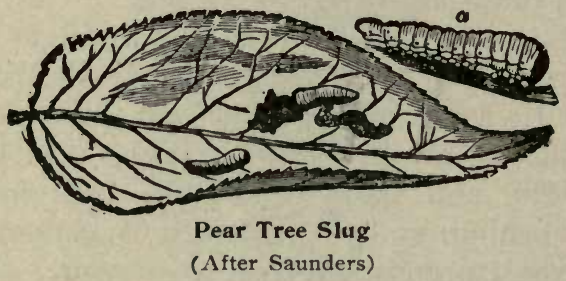

INSECT ENEMIES OF THE FOLIAGE

The leaves of pear, cherry, quince, and plum trees are frequently attacked during June and July by a greenish-black, slimy slug that eats the upper surface. This is the Pear-tree Slug. The adult is a fourwinged black fly that deposits eggs in the leaf early in the summer. The eggs soon hatch into larvae which become full-grown in four or five weeks. They then shed their slimy skins, appearing in clean yellow ones, and soon descend to the ground, which they enter two or three inches, and pupate in oval cocoons. A fort- 
night later the flies emerge. These larvae are easily destroyed by spraying with hellebore or the arsenites.

In a number of the eastern states a small insect, the Pear Psylla, has recently caused serious damage by sucking the sap from the leaves. The insects pass the winter as adults, and in early spring deposit eggs on the bark, especially about the buds. About a fortnight later they hatch into young-called nymphswhich suck the sap from the petioles of the leaves and stems of the young fruit. Recent experiments have shown that the young nymphs may easily be destroyed by spraying with kerosene emulsion.

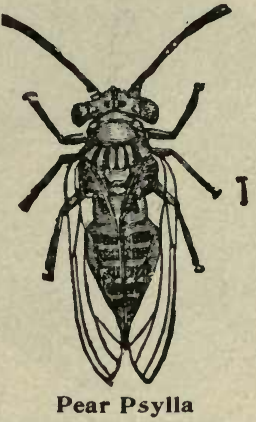

Magnified. (After Slingerland)

\section{FUNGUS ENEMIES}

The Pear Leaf-Blight is the most destructive fungous disease of the pear for which the spraying machine may be successfully used. It occurs both on the foliage and fruit; on the former causing small, discolored spots, and on the latter producing a very injurious cracking of the skin. It appears soon after the leaves develop, in the shape of small dull-red spots on the upper surface; then the lower surface becomes spotted, and the spots gradually change to a dark 
brown color with black specks in the middle. The affected portions enlarge, and finally the whole leaf becomes diseased and falls off. The red spots also appear upon the fruit; the skin becomes much rough. ened and finally splits open in long cracks.

Remedies-Spray twice with the 50 or 60 -gallon formula of the Bordeaux mixture, applying first about one month after the blossoms fall, and again a month later. If more than two applications of the Bordeaux mixture are made after blooming there is danger of

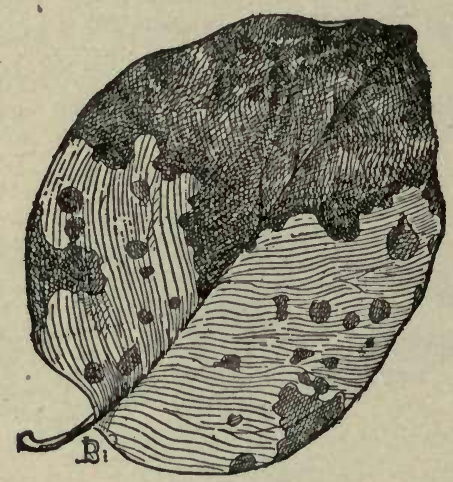

Quince Leaf Blight

giving the fruit a russet appearance. In case of early pears only one application should be made after blooming. If late applications are made the copper carbonate or some similar fungicide should be used. The effect of treatment with the Bordeaux mixture, as shown in one of $\mathrm{Mr}$ Galloway's experiments, is illustrated on page I34.

By adding an arsenical to the Bordeaux mixture, both insect and fungus injuries will be prevented.

The PEAR Scab is a disease very similar to apple scab, the fungus, in fact, being believed by many bot- 
anists to be the same species. At any rate, the chief points in the life-history and remedial treatment are the same as for the apple disease. Spray with dilute Bordeaux mixture, first as soon as fruit buds open; second just before blooming; third as soon as blossoms fall, and fourth about three weeks later.

Care should be taken not to apply the Bordeaux mixture too late in the season. Early varieties should have but one spraying with this mixture after the fruit "sets," and late varieties but two. Where additional applications are needed, use the copper carbonate solution.

Pear trees, especially older ones in southern latitudes, as well as apple trees, are often largely covered with Lichens of various kinds. Recent experiments by $\mathrm{Mr}$ M. B. Waite show that these are destroyed by spraying with the Bordeaux mixture.

The quince is subject to the leaf-blight above discussed as a pear pest, and to various other diseases. As a general rule, it should receive treatmerit similar to that given the pear, although a larger number of sprayings seem to be necessary. 


\section{THE CHERRY}

INSECT ENEMIES OF THE FRUIT

The Plum Curculio, which has already been discussed under The Plum (page 69), is also exceedingly injurious to cherries. The latter, however, usually do not fall off when infested by the curculio larvae, but remain on the tree until the fruit ripens. The remedial measures suggested in connection with the plum are equally applicable to this fruit.

Some varieties of cherries, especially the early ones, are very susceptible to injury by arsenites. Arsenate of lead seems to be the safest poison to use on them. Do not spray early varieties more than twice, or late ones more than three times.

\section{INSECT ENEMIES OF THE FOLIAGE}

The twigs and under surface of the leaves of cherry trees are frequently thickly infested during May and June by small, shining black plant-lice, that suck out the sap and deform the leaves. This insect is the CherRy Aphis. It winters over on the twigs in the egg state. Early in spring the eggs hatch into young aphides that insert their tiny sap-sucking beaks into the unfolding leaves. In a week or ten days they become full-grown, and give birth to young lice, which soon develop and repeat the process. In this way they increase with marvelous rapidity. Late in June or early in July they leave the cherry, migrating to some other plant. Here they develop through the summer, and in autumn a winged brood again appears and 
migrates back to the cherry. These migrants give birth to young that develop into egg-laying females, which deposit small, oval, shining black eggs upon the twigs.

Remedy-Spray with kerowater, kerosene emulsion or whale-oil soap. This can be done most easily and effectively early in spring, when the newly-hatched lice are crowded upon the bursting buds.

The Pear-tree Slug, which has already been discussed as a pear insect, is probably as destructive to cherry foliage as to that of the pear. Its life-history on the two fruits is similar, and the remedies are the same in both cases.

\section{FUNGUS ENEMIES}

The cherry is subject to much the same fungous diseases that the plum is. The leaves are attacked by the Leaf Blight, and the fruit by Brown Rot. The remedial measures already suggested for these diseases are applicable here. 



\section{PART II}

SPRAYING SMALL FRUITS AND

NURSERY STOCK 


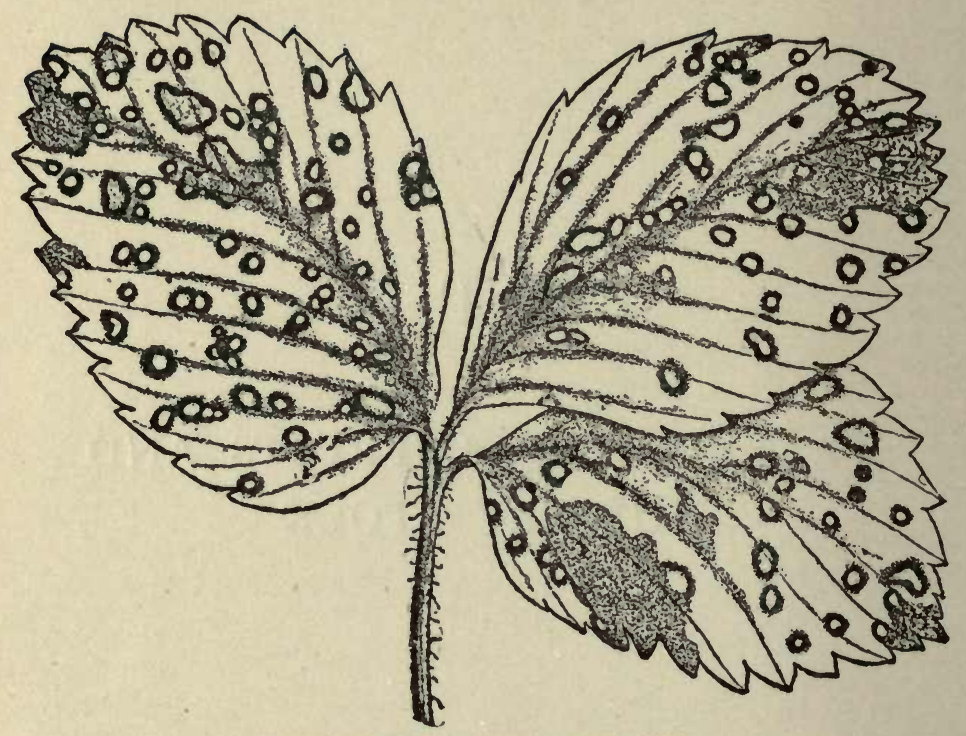

Strawberry Leaf Affected with Blight

(After Garman) 


\section{Spraying Small Fruits and Nursery Stock}

\section{THE STRAWBERRY}

INSECT ENEMIES OF THE FOLIAGE

The transformations of the Strawberry Slug have been well represented by Dr Riley in the figure on page 86. The four-winged fly (3) appears in spring, and deposits its eggs within the tissues of the leaf or stem. The larvae feed upon the leaf, gnawing small, circular holes at first. They develop in five or six weeks into pale green worms $(4,6)$ about threefourths of an inch long. The larvae now go slightly beneath the soil surface, and there they form cocoons (7) within which they change to the pupa state $(1,2)$, and later emerge as flies. In the southern states there are two broods each season, while at the north there appears to be but one.

Remedies-On the non-fruiting plantations this pest may be destroyed by spraying or dusting with hellebore or arsenate of lead. On fruiting plantations this method may be used in localities where a second brood of larvae appears after the fruit is gathered.

The Strawberry Leaf-Roller is a small, brownish caterpillar that folds the leaflets of the strawberry by bringing the upper surfaces together and fastening them by silken cords, and feeds upon their substance till they look brown and scorched. It hatches from eggs laid in spring upon the strawberry plants by a small reddish-brown moth. The larva attains its full 
growth in June, when it is nearly half an inci long, of a brown or greenish color, with a shining yellowishbrown head. It pupates within the rolled leaf, and about midsummer emerges as a moth. These moths deposit eggs for a second brood, that feed upon the leaves late in summer, changing to pupae early in autumn; and, passing the winter in that condition, emerge as moths the following spring.

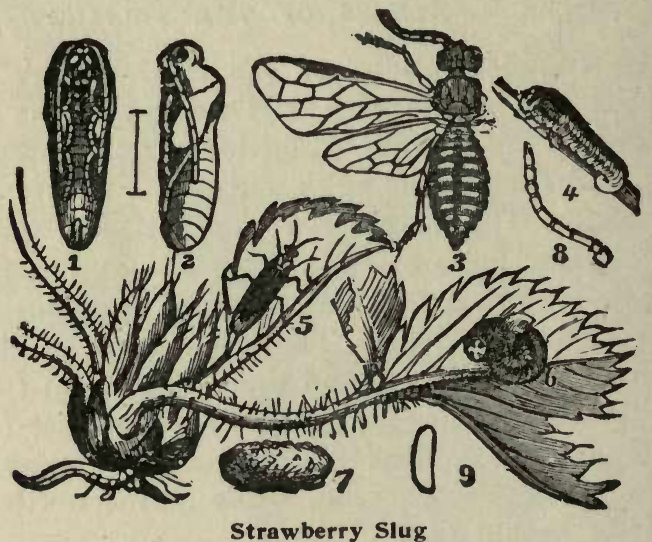

I, 2, pupa; 3, 3, fly; 4, 6, larvae; 7, cocoon; 8, antenna; 9, egg, magnified (After Riley)

Remedies-Mow the field soon after the crop is gathered, and after leaving it a day or two to become dry, burn it over. This destroys the leaf-rollers as well as several other kinds of insects, and the spores of fungous diseases. Scatter a little straw over the field where the leaves are not thick enough to burn well. The plants will not be damaged, but will soon send up a new lot of leaves that will grow rapidly, and be free from insect and fungus attack. If for any reason this method is not desirable, the insects of the second 
brood may be destroyed by spraying or dusting the plants in August with some poisonous insecticide.

The foliage of strawberries is also attacked by certain Strawberry Leaf-beetles, the parents of the StraWBerry RoOT-WORMS. On young non-fruiting plantations, and on fruiting plantations after the crop is gathered, these insects may be destroyed by spraying with an arsenical poison.

\section{FUNGUS ENEMIES}

The Strawberry Leaf-blight or Rust is the most destructive fungus enemy of this fruit. "The presence of the blight fungus," says Professor H. Garman, "is first marked by the appearance of small brown spots, varying from one-sixteenth to one-eighth inch. As they become abundant the spots fuse, forming extensive brown areas, and finally occupy the whole leaf. Eventually most spots show at the upper side of the leaves a rim of dull purple of varying width. Towards fall this change in the color of the leaf is more prevalent. If one of the spots be cut through with a pair of fine scissors, the leaf will be found, at the point where the spot is formed, much thinner than elsewhere, because of the killing and drying out of its substance. Examined under a microscope, the fungus may now be found to have pushed through the tissues of the leaf, and to have formed all over the brown central region of the spot, but most abundantly at its margins, small whitish tufts, looking like microscopic shrubs. These are the fruiting parts of the parasite, and are made up of numerous threads, each bearing at its summit a long jointed spore. As these latter ripen they are set free, and are scattered upon fresh leaves by winds and rains, to germinate there, push into the leaves, and form new spots." The fun- 
gus is propagated by these long spores throughout the summer, but in autumn the threads of mycelium "form solid tissue-like masses in the dead parts of the spots," which finally appear at the surface as small black dots. By means of these dots or nodules the fungus passes the winter. A leaf affected by this disease is represented on page 84 .

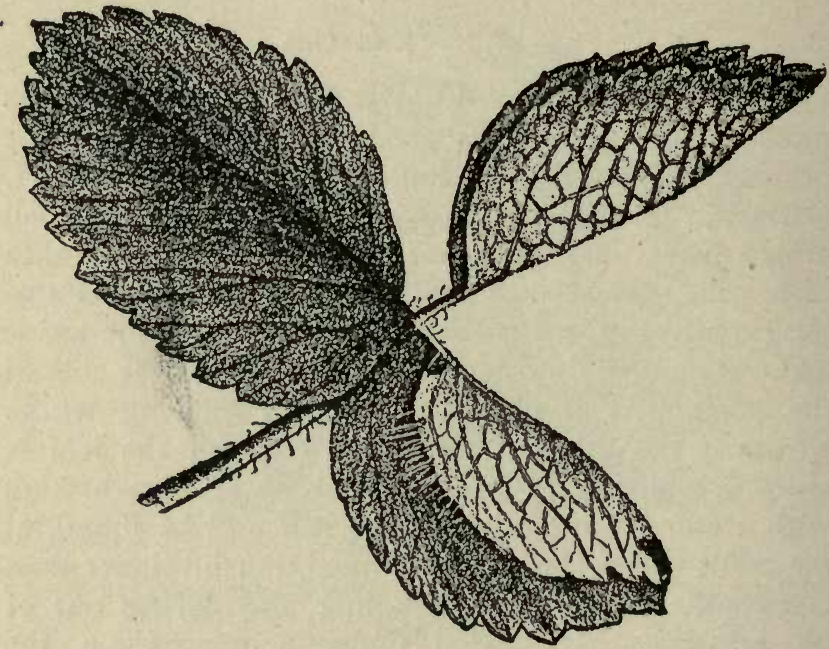

Strawberry Leaf Folded by Leaf=roller

(After Garman)

Remedies-During July and August spray with Bordeaux mixture or ammoniacal solution of copper carbonate, at intervals of two weeks. Try mowing and burning foliage soon after the fruit is gathered, and then spray as just directed. Mowing and burning at this time, without subsequent spraying, is believed to increase rather than diminish the blight, at least 
southward; but mowing and burning may often be done to good advantage, at least in southerly latitudes, in autumn. On the whole the most satisfactory method of keeping strawberry enemies in check is by frequent renewals of the plantation. 


\section{THE CURRANT AND GOOSEBERRY}

\section{INSECT ENEMIES OF THE FOLIAGE}

The most destructive insect enemy of currant foliage is the Imported CUrrant Worm. Early in spring four-winged saw-flies deposit rows of small, whitish, glassy eggs on the principal veins of the under side of the lower leaves. In about ten days the small worms hatch and eat circular holes in the leaf. At first these larvae are whitish in color; they moult at short intervals, first changing to green, then to green with numerous black spots, and at last back again to a plain light green, with a tinge of yellow at the sides and ends. The full-grown larvae descend to the ground, where they spin tough brown cocoons beneath the leaves and rubbish, within which they change to pupae. From these cocoons the flies emerge early in summer, to lay eggs for a second brood, which passes the winter within the cocoons.

Remedy-Spray with hellebore-I ounce to 3 gallons water-as soon as holes appear in lower leaves. Spray again ten days later. Or spray with arsenites as soon as the leaves expand, but never after the fruit sets.

Currant leaves are often specked with white by the Currant Lenf-Hopper, a small, pale-green insect, one-tenth inch long, that lives on the under side and sucks the sap. The chief lamage is done by the first brood, the insects leaving the bushes in early summer, probably preferring at this time the more succulent foliage of other plants. 
Remedies-Spray forcibly with kerowater, or kerosene emulsion, pyrethrum or insect-powder-I ounce to 3 gallons water; or with tobacco decoction. Begin early, before the insects get their wings.

The foliage on the tips of currant and gooseberry stems is often blighted in spring by the FOUR-LINED LEAF-BUG, a small insect represented natural size and

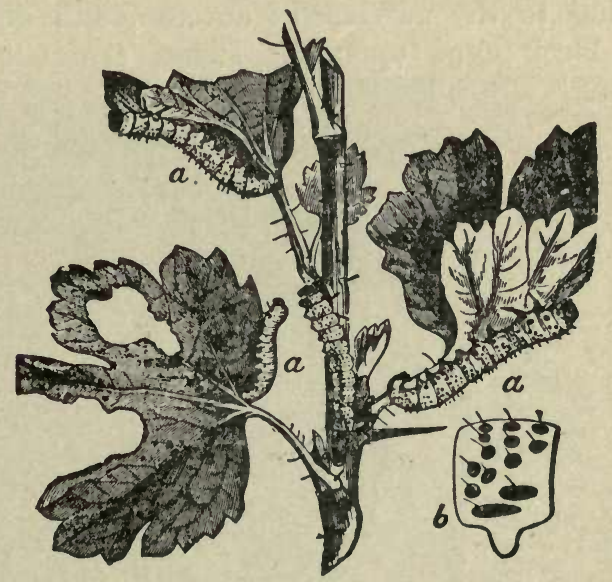

Currant Worms Eating Leaves

(After Riley)

magnified on page 92. The young appear early in spring and suck the sap from the unfolding leaves, causing them to wilt and appear blighted as in the picture on page 93 .

Mr M. V. Slingerland, who has studied this pest thoroughly, finds that its eggs are laid in currant stems and pass the winter there. Consequently pruning the stems between September and April-burning the portions cut off-will be a partial preventive; and spraying with kerosene emulsion early in the season, when 
the insects are immature, will destroy many of them. The only other remedy suggested is that of jarring the pests into pans containing kerosene and water.

The Currant Aplins is a small, yellowish insect found on the under sides of curled and blistered currant leaves early in summer. Such leaves are generally tinged with reddish above. The insects apparently migrate to some other plant during the summer, returning to the currant in autumn, and depositing small, black eggs upon the stems, especially about the buds.

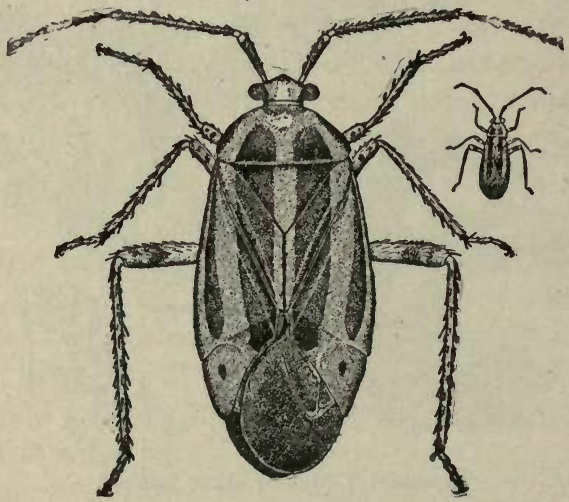

Four=lined Leaf=bug

Magnified and natural size. (After Slingerland)

Remedies-On account of the deformed leaves, these insects are difficult to reach with insecticides. Spray with kerowater or kerosene emulsion or tobacco decoction quite early in the season, before the foliage has expanded.

\section{FUNGUS ENEMIES}

For many years it has been impracticable to grow foreign varieties of gooseberries in the United States, 
on account of the attacks of the GooseberRy Mildew. According to Dr B. D. Halsted, this mildew "first makes its appearance upon the young half-grown leaves, and the unfolding terminal bud of the shoot. In its early stage it has a cobwebby appearance, which soon becomes white and powdery from the development of the light summer spores. Soon after this, thin patches of the same character may be found upon the forming berries. Usually one side is more attacked

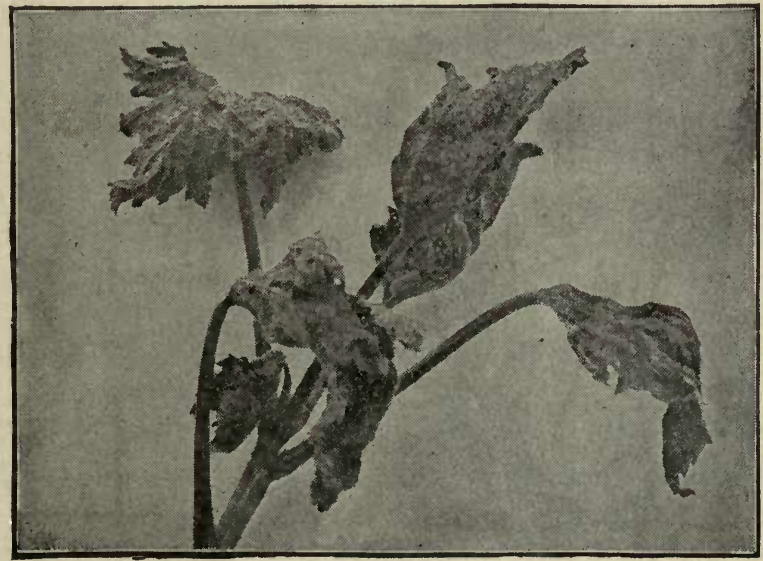

Currant Leaves Blighted by Leaf=bug

(After Slingerland)

than the other, and as the berry continues to grow it becomes one-sided or curved, because the fungus retards the development upon the infested side. If the berry is entirely covered, its further development is generally checked. Later in the season the leaves, and especially their petioles, and the young stems bearing them, turn to a rusty-brown color, and become thickly coated with the fungus. The berries at the 
same time are covered with brown patches of mycelium, which may readily be peeled off from the smooth skin of the fruit."

Remedies-Spray with a solution of potassium sulphide (liver of sulphur) at the rate of one-half ounce to I gallon water. Begin as soon as the leaves commence unfolding, and repeat the application at intervals of eighteen to twenty days. The sulphide dissolves more readily in hot than in cold water. This treatment has proven entirely efficacious for a number of years at the New York experiment station. Early in the season the Bordeaux mixture may be used instead of the sulphide if more convenient, and it is desirable to spray with Bordeaux mixture after the fruit is gathered, to prevent the various spotdiseases, that often cause the foliage to drop off late in summer.

General Treatment-One of the most successful currant growers in New England gives his bushes three sprayings each season, namely: first, with copper sulphate solution in early spring before buds open; second, with Paris green as soon as leaves come out; third, with Bordeaux mixture and Paris green after fruit is picked. 


\section{THE GRAPE}

\section{INSECT ENEMIES OF THE FOLIAGE}

The Grape-vine Flea-beetle is a small, steelblue beetle that is often very destructive to grape-vines. As soon in spring as the buds swell the beetles attack them, and continue feeding for three or four weeks, during the latter part of the time depositing small, orange-yellow eggs in clusters on the under sides of the leaves. The eggs hatch into small, dark-colored larvae that gnaw irregular holes in the leaves. When fully grown (three or four weeks after hatching), they are about three-tenths of an inch long, brown in color, with six legs, and four or five black dots on the back of each ring or segment of the body. The head is black, and there are numerous hairs on the body. They now enter the soil, pupate, and a few weeks later emerge as beetles, which feed upon the foliage and lay eggs for a second brood of larvae.

Remedy-Spray with arsenites as soon as beetles appear in spring; or else with the arsenited Bordeaux mixture. Repeat in ten to fourteen days if necessary.

\section{FUNGUS ENEMIES}

The Black Rot of grapes has long been recognized as the most destructive fungous disease which American vineyardists have encountered. Generally the fungus first appears in the shape of round, reddishbrown spots on the grape leaves. About a fortnight later the attack on the berries will be noticed. The effect on these is most disastrous; as the mycelium develops among the cells of the fruit the berries stop 
growing, and finally become disorganized, shapeless, juiceless masses, shriveled to one-half their proper size and fit only to develop the spores of the destroying fungus. And they do produce these spores, which are massed together in little black pustules scattered over the surface of the withered skin.

This Black Rot fungus is most destructive in southern latitudes. As far north as northern Ohio ard western New York it is much less virulent than in Tennessee or the Carolinas. Like most fungous diseases it develops with greater rapidity during damp, hot weather, or when nights with heavy dews alternate with hot days.

Remedies-Spray with the copper sulphate solution before the buds start, then with the Bordeaux mixture four or five times, making the first application when the first leaves are half-grown; the second, when the fruit has set, repeating the later sprayings at intervals of about fifteen days. If disease persists so later sprayings are necessary, substitute the ammoniacal solution of copper carbonate for the last one or two sprayings, to avoid spotting the fruit.

An account of the development of the Down: MILDEW or BRown Rot of grapes has already been given in the Introduction (pages 7-9). This disease has been, in years past, extremely destructive over a wide area; and it attacks disastrously both the foliage and fruit. In southern latitudes it is said to be most injurious to the former.

Remedies-The Bordeaux mixture is a practical and efficient preventive of this disease. Spray first a week or ten days before the vine blossoms; second, as soon as the berries are well set; and third, about three weeks later. In very wet seasons it may be desirable to spray a fourth time, but this is seldom done. 


\section{THE RASPBERRY}

INSECT ENEMIES OF THE FOLIAGE

The Raspberry Slug is the larva of a fourwinged black fly with a reddish abdomen, which deposits eggs in the leaf during spring. They hatch into small, whitish worms that feed upon the tender foliage, and in a few weeks become full-grown. They are then $3 / 4$ inch long, of a dark green color, and have the body thickly covered with spinose tubercles. The slugs now descend to the ground, and construct rather firm cocoons slightly beneath the soil surface. They remain in these cocoons until spring, when they come forth as flies.

Remedy-Spray the infested bushes with powdered hellebore. Use from one-half to one pound of hellebore to 50 gallons of water, and apply forcibly, as suon as the worms appear.

\section{FUNGUS ENEMIES}

The Anthracnose or CAnE-Rust of the raspberry is one of the most vexatious diseases with which the fruit-grower has to contend. Infested canes are characterized by having numbers of peculiar, grayish, depressed spots upon the surface, the spots usually having a dark purple margin. This injury is accompanied by a splitting or cracking of the bark, which becomes deeper as the cane ripens, and finally extends nearly to the pith. The spores are developed usually in the central portions of the spots, appearing to the unaided eye as yellowish elevations. Canes so attacked become dwarfed and worthless. 
Remedy-The raspberry is very sensitive to the corrosive action of fungicides, and it must be sprayed with care. Recent experiments at the Ohio Station indicate that the dilute Bordeaux mixture may be used to advantage against this disease, although it is not a complete remedy. Apply once before the leaves come out, and two or three times afterward, though not after the blossoms open. "Care should be taken to direct the spray to the young growth, and avoid the old canes after the first application." In Canada the recommended treatment is to spray with copper sulphate solution before buds burst, and with Bordeaux mixture ten or fifteen days after leaves open, repeating the latter soon after the old canes are cut out. 


\section{NURSERY STOCK}

Nursery trees are particularly liable to attack by the San Jose scale and others similar to it. The use of the lime, salt and sulphur wash and fumigation of dormant stock are the standard remedies. The leaves of young apple trees are frequently rolled together at the tips of the terminal twigs by a greenish-yellow, slightly hairy worm about an incl long. This is the Lesser Apple Leaf-Roller. Its life-history is as follows: The eggs are laid in spring on the leaves of apple and other plants, the larvae soon hatching in devour the foliage, some of which they roll into a protective covering. Here they feed for about a month, when they pupate within the folded leaves, and a week or so later emerge as small orangeyellow moths; these moths lay eggs for another brood of larvae, the imagos from which appear in August, being also of the same orange color. These in turn lay eggs for a third brood of worms, which emerge during October as glistening reddish-gray moths, which pass the winter in rubbish heaps and fence corners and deposit eggs the following spring.

One often finds during winter, upon the twigs of nursery trees, masses of dry brown leaves, which, when pulled apart, are seen to surround a long, tubular, horn-like case. These cases contain a brownish worm or caterpillar, about half an inch long. This is the LEAF-CRUMPLER, and it often becomes one of the most injurious of nursery pests. The parent is a small grayish moth $(d)$ that deposits its eggs during June and July on apple, quince and other trees. These eggs soon hatch into small brownish worms that construct tubular, silken cases $(a)$ within which they remain 
concea.ed when not eating. As they grow larger they draw about the openings of their abodes many partially eaten leaves, so that by autumn there is quite a bunch surrounding each case $(b)$. At the approach of cold weather the cases are attached to twigs by silken threads, and thus the winter is passed. As soon as the leaves appear the larvae attack them, frequently eating out the flower buds as well. They feed until June, when they pupate within the cases. A fortnight later the moths emerge.

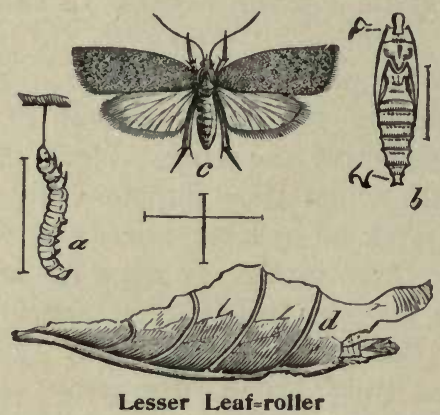

$a$, larva; $b$, pupa ; $c$, moth; $d$, rolled leaf

(After Riley)

- The Apple Leaf-SKeletonizer s a brownish or greenish larva, which spins a web upon the upper surface of the leaf, and eats the parenchyma, giving the foliage a scorched appearance. The larvae hatch from eggs laid late in spring by a little moth, and as they grow older they spin a slight protective silken web on the upper surface of the leaf, beneath which they feed. When full grown $(a)$ they vary from an olive or pale green color to brown, are about half an inch long, and have four black shining tubercles on the back, just behind the head. About midsummer they pupate in 
slight cocoons, and two weeks later the moths emerge. Eggs are laid by these moths for the second brood of larvae, which when full-grown hibernate in thin cocoons.

Remedies-All three of these pests are open to destruction by spraying with arsenites. In regions

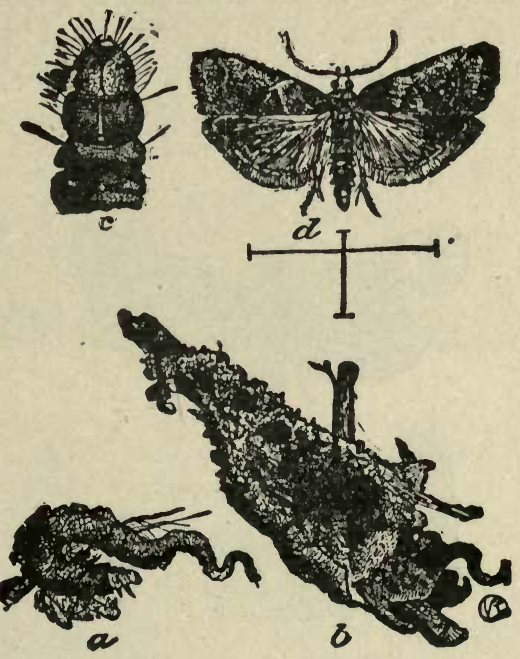

Leaf $=$ crumpler

$a$, larval case; $b$, larval case with dead leaves; $c$, front part of larva; $d$, moth, magnified. (After Riley)

where the Powdery Mildew is injurious as well as these, a combination treatment may be employed, adding five or six ounces of Paris green to each barrel of Bordeaux mixture. Where fungicide treatment is not necessary, spray with arsenites and lime, adding the lime to prevent injury to the young and tender foliage, unless arsenate of lead is used, as explained in the Introduction, whenever either of the insects threaten injury,-the earlier the better. 


\section{FUNGUS ENEMIES}

There are at least three fungous diseases of young nursery trees to prevent which spraying pays. They are: (I) the PeAR LeAF-BLight, which affects quince as well as pear stocks; (2) the Powdery Mildew, which occurs upon apple and cherry, and (3) the LEAF-BLIGHT or LEAF-SPOT of the plum and cherry. According to Dr B. T. Galloway, the body or vegetative system of the PEAR LeAf-BLight consists of

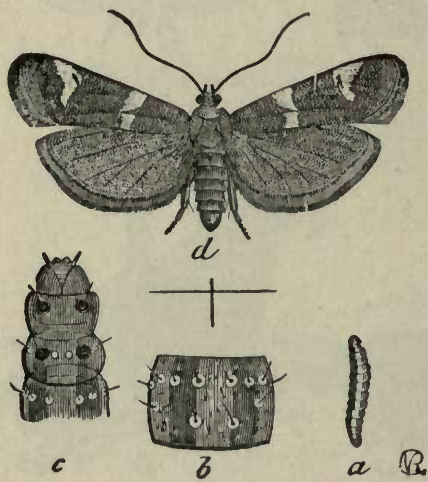

Leaf-skeletonizer

$a$, larva; $b$, part of back, magnıfied to show markings; $c$, head and front part of larva, magnified; $d$, moth, magnified. (After Riley)

very minute, short, colorless filaments, which grow between and through the delicate cells of the leaf, "destroying all the latter with which it comes in contact, and using their nourishment for building up its own structure. As a result of this process, the leaf shows, here and there on the surface, small, more or less circular, dark brown spots; these spots rapidly enlarge, and by running together soon cause the entire leaf to turn brown and then fall off. Before the latter 
takes place, however, a close examination of the diseased spots will reveal numerous little black specks; these contain the spores or reproductive bodies of the fungus, which escape by rupturing the cuticle of the
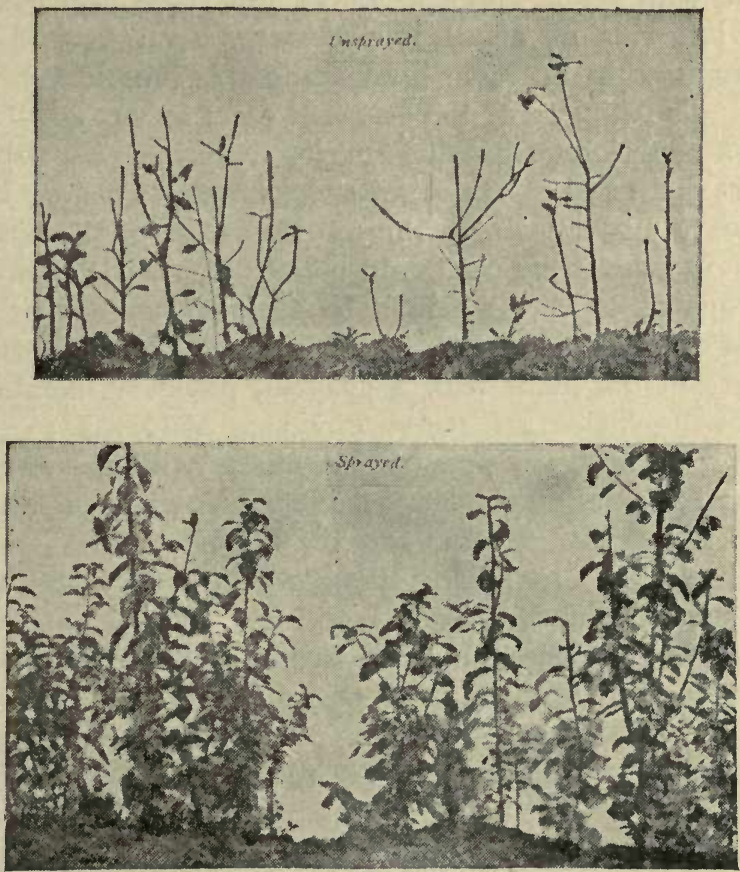

Spraying for Plum Leaf=blight

(After Galloway)

leaf with which they are covered. Under proper conditions of moisture and heat the spores germinate, and if this takes place on a pear leaf, the germ tube bores its way into the tissues, soon develops into colorless filaments, like those already described, and these in 
turn give rise to more spores." The fungus passes the winter by means of the late summer spores which remain attached to the fallen leaves.

Remedy- "Spray first with the Bordeaux mixture when the leaves are about two-thirds grown; then follow with other applications of the same preparation at intervals of about twelve days, until five or six sprayings in all have been made." (Galloway.)

The fungus of the Apple Powdery Mildew differs materially from the species affecting pear leaves just discussed. "Its vegetative system," says Dr Galloway, "instead of growing on the inside of the host is almost wholly external, and obtains its nourishment by means of suckers which it sends into the cells of the leaf or stem as the case may be. It covers the various parts of the plant with a grayish, powdery, meal-like growth-hence the name Powdery Mildew."

Remedics-"Spray the seedlings with the ammoniacal solution or copper carbonate, first when the leaves are about half grown, and thereafter at intervals of twelve days. Following this plan three sprayings will usually be made before budding, and at least two after this operation, making five in all." (Galloway.) Or the Bordeaux mixture may be used.

The LEAF-BLIGHT of the plum and cherry may be prevented by spraying with the Bordeaux mixture. Apply first when the leaves are one-third grown. "Between this date and the time for budding three more applications should be made at as nearly regular intervals as possible. Ten days or two weeks after the buds are inserted make the fifth application, then follow with the sixth two weeks later." The effect of spraying plum stocks is well shown in the picture on page I03, reproduced from the Journal of Mycology. Be sure that there is an excess of lime in the Bordeaux mixture. 


\section{PART III}

SPRAYING SHADE TREES, ORNAMENTAL PLANTS AND FLOWERS 


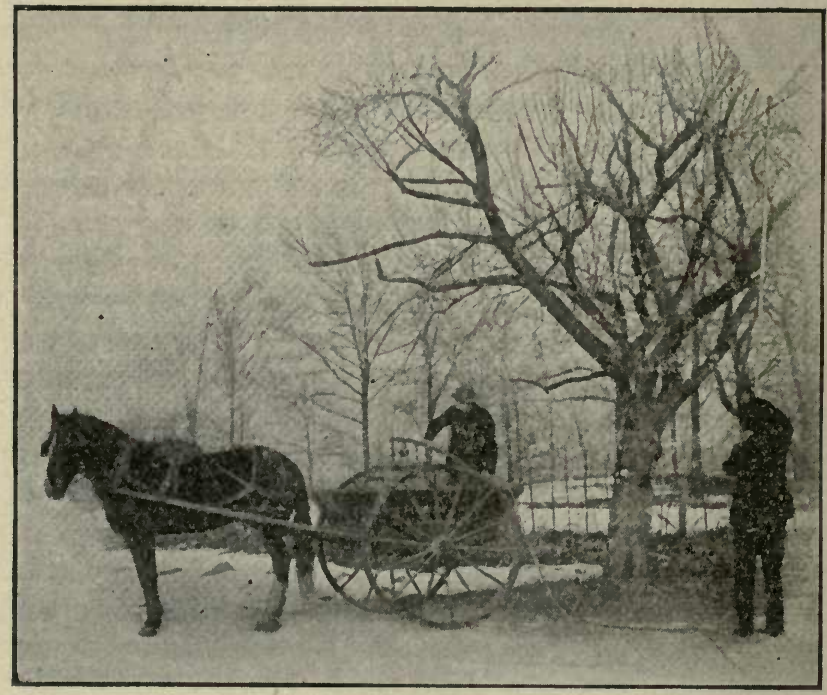

An Outfit for Spraying Shade Trees

(From Connecticut Experiment Station) 


\section{Spraying Shade Trees, Ornamental p I a n t s a nd Flowers}

\section{SHADE TREES}

\section{INSECT ENEMIES OF THE FOLIAGE}

The Woolly Maple Bark-Louse is often one of the most destructive shade-tree pests. Its presence is shown in spring and early summer by the occurrence upon the twigs of a brown, circular, leathery scale about $1 / 4$ inch in diameter, beneath which is a peculiar white, fluffy, cottony mass. In the spring there may be found, in each of these masses, great numbers (from 700 to I000) of small, white, spherical eggs. Early in summer these eggs hatch into young lice, which scatter over the trees, wandering about on the twigs and leaves for a few days, and, finally, fixing themselves upon the lower leaf surface, insert their tiny beaks and suck out the sap. They remain in this position several weeks, when a few of them become fully developed winged males. These mate with the remainder, which are females, and soon die. But the females remain upon the leaves until nearly time for the latter to fall in autumn, when they desert them and migrate to the twigs, attaching themselves by inserting their beaks into the bark. Here they remain until spring, the eggs gradually developing.

Remedy-Spray infested trees in June, when the lice have just hatched, with kerowater or kerosene emulsion. 
The twigs of deciduous and coniferous trees are often infested during winter by small bags or sacs (e) suspended from the leaves or branches. If one of the larger of these bags be cut open, there will be found within it a brown, membranous shell (the pupa-case of the moth) filled with many small, yellow eggs $(e)$. In this condition the BAG-WORM or BASKET-WORM passes the winter. Late in spring the larvae hatch, and form

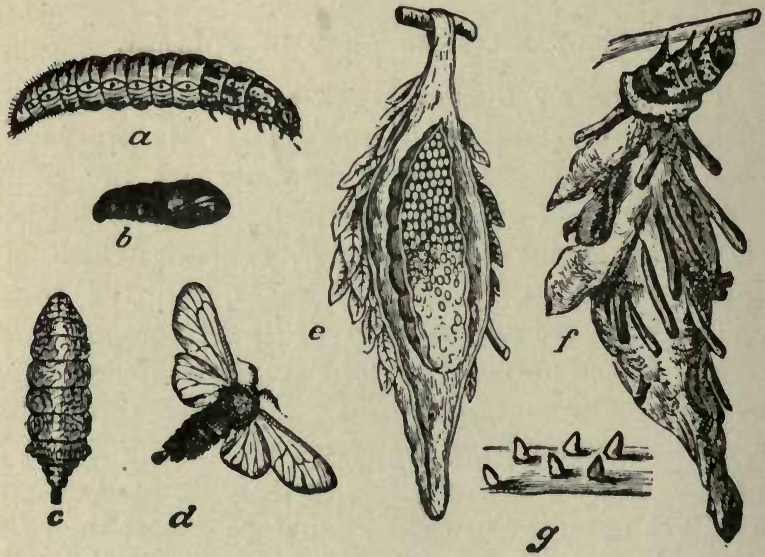

Bag=worm

$a$, larva; $b$, male pupa; $c$, female moth; $d$, male moth; $e$, bag and pupacase cut open to show eggs: $f$, full-grown larva with bag; $g$, young larvae with their conical coverings. (After Riley)

little cases of fragments of leaves fastened together by silken threads. Beneath these cases $(g)$ they feed upon the foliage, enlarging them as the larvae develop, and during later life using bits of twigs or stems in their construction. When fully developed, the worms descend to the earth by means of silken threads, and crawl about until they reach the bases of other trees, which they ascend. This is the way the species 
migrates. The larvae pupate within the cases, and about three weeks later change to moths. The two sexes of the moths differ greatly, the male $(d)$ having well-developed wings, while the female $(c)$ is wingless. The latter deposits her eggs in the empty pupa-case from which she has emerged, falls to the ground, and dies.

Remedies-Spray with an arsenical poison early in summer when the worms are young. Pick off the cases in winter.
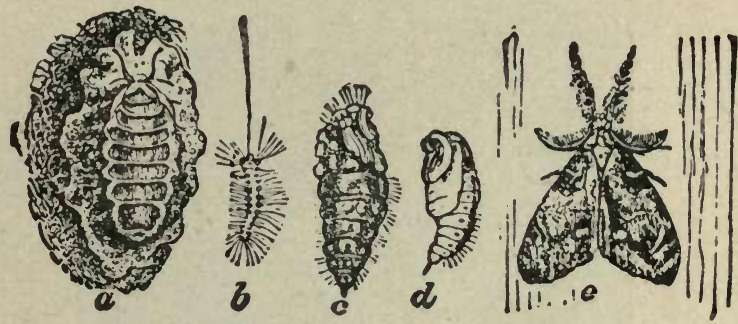

White=marked Tussock $=$ moth

$a$, female moth on cocoon; $b$, young larva hanging by thread; $c$, female pupa; $d$, male pupa: $e$, male moth. (After Riley)

The larvae of the WHITE-MARKED TUSSOCK-MOTH is one of the most beautiful of our caterpillars. If the trunks or larger limbs of maple, apple, elm, or any other of the trees infested by this insect, be examined in autumn or winter, one may find, scattered here and there upon the bark, thin gray cocoons, many of them being covered with large bunches of spherical white eggs fastened together by a protecting froth-like mass. In May, soon after the leaves come out, these eggs hatch into small caterpillars, which feed upon the foliage, becoming full-grown in six or seven weeks. Their general color is bright yellow, with head and tubercles on rear of back red, and four cream-colored 
tufts on back. About the middle of July the caterpillars spin thin, whitish cocoons upon the bark, and a fortnight later come forth as moths. These lay eggs for a second brood, wlich complete their transformations before winter sets in. The male moth differs

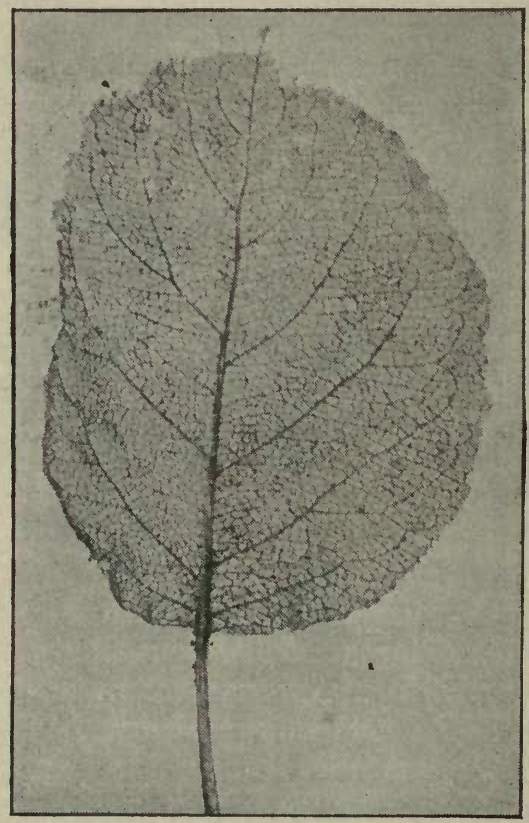

Apple Leaf

Denuded by young Web-worms

greatly from the female moth, the former being winged $(e)$, while the latter is wingless $(a)$. The female crawls upon the top of the cocoon $(a)$ as soon as she emerges from the pupa state, where, after mating, she deposits her eggs in a single mass and dies. 
Remedies-Spray trees as soon as caterpillars are noticed, with arsenate of lead or some other arsenical poison. Pick off egg cases in winter.

The work of few insects is more universally known than that of the FALL WEB-WORM. Late in summer and early in autumn the conspicuous, unsightly webs of this pest may be seen in nearly every orchard and hedgerow over a large portion of the United States. The adult is a pretty, white moth $(c)$, which deposits eggs on the leaves of various trees early in summer.
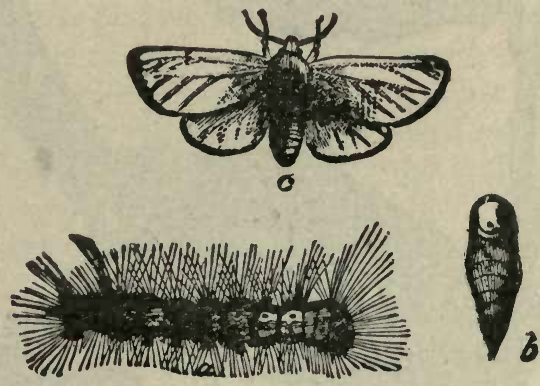

Fall Web=worm

$a$, larva; $b$, pupa; $c$, moth. (After Riley)

These soon hatch into young caterpillars that begin at once to spin a protective web. They feed upon the parenchyma of the foliage, leaving the network of veins, and grow quite rapidly, enlarging the web as they develop. The full-grown larvae are a little more than an inch long, with the body densely clothed with yellowish hairs. They now leave their nests and descend to the ground, where they spin slight silken cocoons within which they change to pupae.

Remedies-It is an easy matter to cut the webs off and burn or crush the larvae. The pests may also 


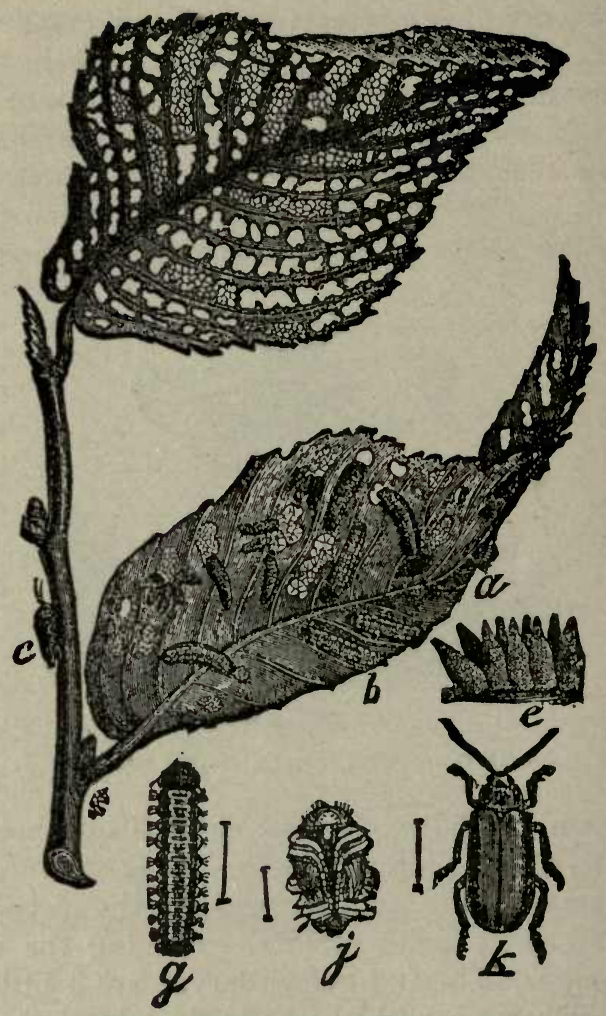

Transformations of the EIm=leaf Beetle (After Riley) 
be destroyed by spraying with an arsenical poison when the larvae are young.

During recent years the Imported Elm LeafBEETLE has been exceedingly destructive in many cities of the eastern states, to that most beautiful of shadetrees, the elm. The eggs $(a)$ are laid on the under side of the leaf in two or three rows. In about a week the larvae hatch and begin eating the leaves, causing them to look as if riddled with fine shot. They become fully grown $(g)$ in two or three weeks, when they descend to the ground, and change to pupae $(j)$. Ten days later the perfect beetles ( $c$, natural size; $k$, mag. nified) come forth and eat the leaves, although the damage done by the insect in this state is less than that done by larvae. There are three or four broods each season, and the beetles pass the winter in hollow trees and under old leaves.

Remedics-Spray with arsenate of lead when the eggs are being laid, in order to kill the larvae before they have done any damage. The addition of a little flour to the poison mixture seems to render it more effective. To reach the tops of high trees a pump of considerable power is required. In July destroy the larvae as they come to the ground to pupate.

An excellent discussion of shade-tree insects and methods of controlling them by Dr L. O. Howard may be found in the yearbook of the United States Department of Agriculture for 1895 . 


\section{THE ROSE}

\section{INSECT ENEMIES OF THE FOLIAGE}

The Rose Slug is the young or larva of a fourwinged saw-fly. It eats the pulp of the leaves, giving the foliage a scorched appearance. The eggs are laid singly in the skin of the leaf, and the larvae hatch in about a fortnight. They become full-grown in three
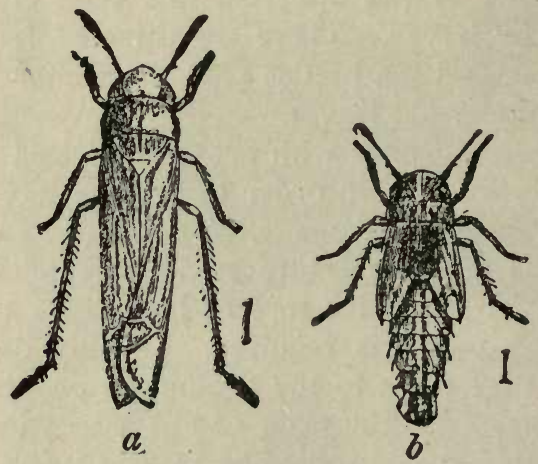

Rose Leaf-hopper

$a$, adult; $b$, pupa; magnified

weeks; they have a small, round, yellowish head, and a green body, which is soft and nearly transparent. Leaving the bushes they burrow into the soil an inch or two and make oval cocoons of silk mixed with particles of earth. They remain in these until the following season, when they emerge as flies.

Remedies-Spray with arsenate of lead or hellebore. 
The Rose LeAf-Hopper is a small whitish insect, found on the lower surface of rose leaves, sucking out the cell contents and giving the upper surface a whitespotted appearance. The adult $(a)$ is a little more than I-IO inch long, with a yellowish-white body, and white semi-transparent wing covers. It has long hind legs, by means of which it is enabled to make tremendous leaps when disturbed.

Remedies-These little pests are much easier to destroy before they are fully developed than afterwards. Spraying or dusting with pyrethrum, or

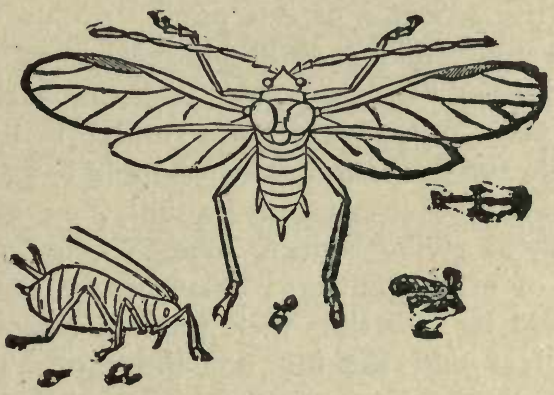

Aph is

$a$, wingless form, magnified; $b$, winged form, magnified; $c$, same, natural size (After Saunders)

insect-powder, is a simple and efficient remedy. Tobacco, in the form either of a powder or a decoction, is also good; and kerosene either in mechanical mixture or in emulsion will destroy the pests.

\section{FLOWERS AND POTTED PLANTS}

Greenhouse plants are often seriously injured by minute, reddish mites that congregate on the lower leaf surface, spinning a fine protective web and sucking out the juices of the plants through their tiny 
beaks. These are ReD SpIDERs. They multiply beneath their silken webs, where one may find colonies of individuals (so small as to be scarcely visible to the naked eye) in all stages of existence. The infested leaves assume a yellowish hue, and many of them finally fall off.

Remedies-The Red Spider flourishes best in a dry atmosphere. It is seldom troublesome in greenhouses where the air is kept saturated with moisture and the plants are sprayetl with water every day. In window gardens the plants should be sprayed with water or soap-suds every day, as soon as they show signs of the presence of this pest.

There are many different species of ApHIDES, Plant-lice, or "Greenflies," affecting various flowering-plants. But all are quite similar in life-history and habits, and the same remedies apply to each. They all multiply with marvelous rapidity, on account of their habit of giving birth to living young without the presence of male aphides. They mature rapidly, and obtain food by inserting their pointed beaks into the stem or leaf and sucking out the sap. There are generally two forms of them, one being winged $(b, c)$ and the other wingless $(a)$. These insects are the commonest pests of the flowering-plants.

Remedies-Spray with strong soap-suds or kerosene in mechanical mixture or emulsion, fish-oil soap, whale-oil soap, or tobacco decoction. 


\section{PART IV}

SPRAYING VEGETABLES, FIELDCROPS AND DOMESTIC ANIMALS 


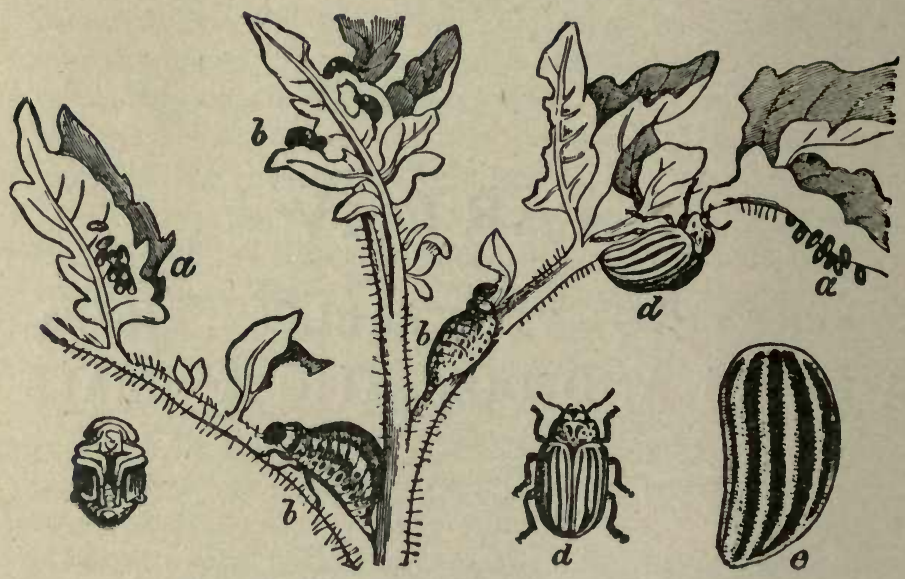

Transformations of the Colorado Potato=beetle (After Riley) 


\section{Spraying Vegetables, Field-Crops and Domestic Animals}

\section{THE POTATO}

\section{INSECT ENEMIES OF THE FOLIAGE}

The Colorado Potato-beetle deposits its orangecolored eggs $(a)$ in masses, varying in number from a dozen to fifty or more, on the under surface of the potato-leaf, and occasionally also upon the leaves of grass, smart-weed, or other plants in the potato field. They hatch about a week later into peculiar little grubs (b) that feed upon the foliage a few weeks. They then descend to the ground, where just beneath the soil surface, or under the rubbish above it, they change to pupae $(c)$. About ten days later they emerge as perfect beetles. There are from two to four annual broods, the number varying with the latitude; and the insect hibernates in the beetle state.

Remedies-Spray with almost any of the arsenical poisons. Arsenate of lead has been found best by the Maine Experiment Station. The application should be made ás soon as the beetles appear, in order to kill off the first brood, and it must be repeated as often during the season as is necessary to keep the pests in check.

The FLEA-BEETLE is one of the most troublesome insect pests affecting potatoes. Although very small it appears in enormous numbers and eats small holes in the surface of the leaves. They thus not only injure the tissues of the leaf directly, but the holes they make 
furnish easy access to the spores of disease-producing organisms.

Remedies-Spraying with arsenate of lead and Bordeaux mixture will prevent to a great extent at least the depredations of this pest. The more thorough the application the more effective will it be.

\section{FUNGUS ENEMIES}

There are at least two distinct fungous diseases which are called the Potato Rot or Potato Blight. One of these is the Late Blight or Downy Mildew, due to the fungus Phytophora infestans; and the other is the EArly Blight or Leaf-Spot Disease, due to the fungus called Alternaria solani. They may usually be distinguished by the fact that leaves affected by the former have on their under surface a white, velvety mould, visible to the naked eye, but more readily seen through the microscope; with the Early Blight no such mildew is present. With both, the foliage of plants attacked becomes spotted with brown, and the spots gradually enlarge, finally involving the whole leaf, and then cause the stems to wilt and wither.

According to Professor F. L. Scribner, the lifehistory of the Downy Mildew Potato Rot Fungus may be summarized as follows: "The spores lighting upon the leaves of the potato germinate in drops of dew or rain, and the product of germination-the zoöspores - penetrate to the interior tissues of the plant, and after growing for a time through these tissues, the mycelium sends out, chiefly from the under surface of the leaves, slender fruiting branches, whereon are produced a new crop of spores. These may carry the disease to the other plants in the field, or to the other parts of the same plant; that is, they may serve to spread the disease in the tops, which we term blight, over the entire field, or by being washed into the ground they may 
reach the tubers and cause the rot. The fungus once having gained entrance to the tubers, may or may not vegetate rapidly. Its presence, however, is soon made evident by a browning of the flesh underlying the skin, and by more or less extensive discoloration and depression of the latter." When such affected tubers are planted, the disease is very likely to develop in the plants from them.

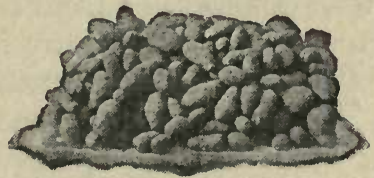

$a$

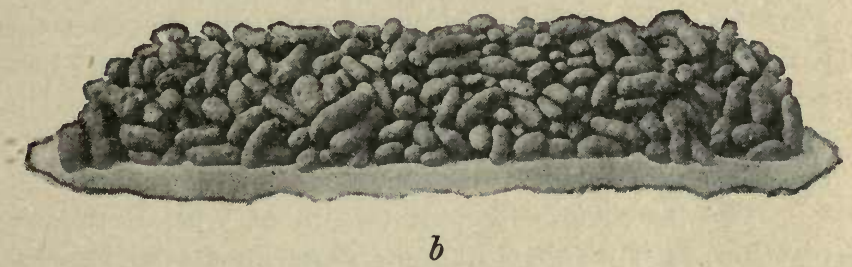

(a) Yield of Unsprayed Plot: (b) of Sprayed Plot (After Jones)

The IARLY BLIGHT appears early in summer in the shape of small brown, brittle spots, scattered over the leaf. Careful inspection shows that their upper surfaces are more or less roughened by darker areas rising above the dead gray tissue. The spots gradually enlarge, and finally run together to form large brown patches, the intermediate tissues becoming yellow or sickly green in color. The entire plant finally withers, and dies long before the proper period, the tubers being small-generally less than half full size. But the tubers do not rot and are of fair quality. This fungus has proven difficult to study in the field, 
the spores being produced only in the later stages of the disease. It winters over in the spore stage on the dead vines.

Remedies-A number of experiments have shown that these diseases may be prevented by spraying with the Bordeaux mixture, provided the seed potatoes used are free from infection. To be sure of this, seed should be obtained from regions where blight and rot do not occur upon potatoes, or from fields which were sprayed the year before. Then spray from two to four times with the Bordeaux mixture, making the first application when the vines are about one-half grown, or earlier if signs of the disease appear, and repeat the application when it is washed off-in about a fortnight usually. Add half a pound of London purple or Paris green to each barrel of the mixture whenever the Colorado beetles threaten injury. While the best results are most likely to be reached when the seed is not infected, very satisfactory ones are obtained from spraying crops from ordinary seed.

The beneficial effect of treatment with Bordeaux mixture, as it resulted in some experiments by Professor Jones, of Vermont, is shown on page 121 . The treated vines yielded marketable tubers at the rate of 29 I bushels per acre, while those untreated yielded only at the rate of $99^{1} / 2$ bushels per acre.

Brown Rot-Besides the two maladies already discussed, there is a form of blight and rot called "brown rot," due to bacteria. This occurs on tomatoes and egg plants as well as potatoes, and is worst in the south. There is no spotting of the leaves as in the preceding blight, but the first symptom is a sudden wilting of the entire top, which is soon followed by the shriveling and blackening of the leaves and stems. The disease passes from the stem to the tubers, causing a browning of the interior, which is soon followed by 
soft rot. The beetles or other insects feeding upon the diseased plants carry the germs to the healthy ones. The germs also live over in the soil.

Remedies-Avoid land which has recently borne diseased potatoes, tomatoes or egg plants. If the disease occurs, all wilting vines should be removed and destroyed at once and the tubers, if stored, should be kept cool and dry. The chief remedial measure consists in thorough spraying with arsenites, or Bordeaux mixture and arsenites, to keep the vines free from the insects which carry the germs. 


\section{THE CABBAGE}

\section{INSECT ENEMIES OF THE LEAVES}

The transformations of the IMPORTED CABBAGEwORM - the most destructive insect affecting cabbage -are illustrated in the picture on page 125 . The adult is a common white butterfly, which deposits, singly or in clusters of two or three each, small, yellowish-white eggs upon the cabbage. The eggs soon hatch into little green larvae that feed upon the leaves. In about two weeks they become full-grown $(a)$, when they desert the cabbage plants, and finding some suitable shelter-beneath a board or under a coping of a fence -change to chrysalids $(b)$. They remain in this condition about ten days, when they emerge as butterflies, to lay eggs for another brood of worms. The winter is passed in the chrysalis state.

Remedies-Pyrethrum (insect-powder or buhach), hot water and kerosene either in mechanical mixture or emulsion, are the best remedies. The insect-powder may be applied as a dry powder or be mixed with water, in the proportion of I ounce to 4 or 5 gallons of water, and sprayed upon the plants. Dr Riley states that "every worm visible upon the cabbages may be killed by the use of hot water at the temperature of 130 degrees Fahrenheit. The water may be boiling hot when put in the watering-can, but it will not be too hot when it reaches the cabbage leaves." Kerosene in mechanical mixture or emulsion can advantageously be used when the plants are young, though there would appear to be danger of tainting the heads if applied to the fully developed plants. Whichever method of treatment is adopted, it should be 
carried into practice at frequent intervals, thus keeping the worms well in check. If the plants are treated with. insect-powder once a week during the time the worms are present, they will cause little or no trouble.

There are several other caterpillars affecting cabbage-especially the Cabbage Plusia and the Zebra CATERPILLAR-which sometimes necessitate a spraying with kerosene emulsion or insect-powder.

The Cabiage Apilis is a small, greenish insect, generally covered with a whitish, mealy coating, that

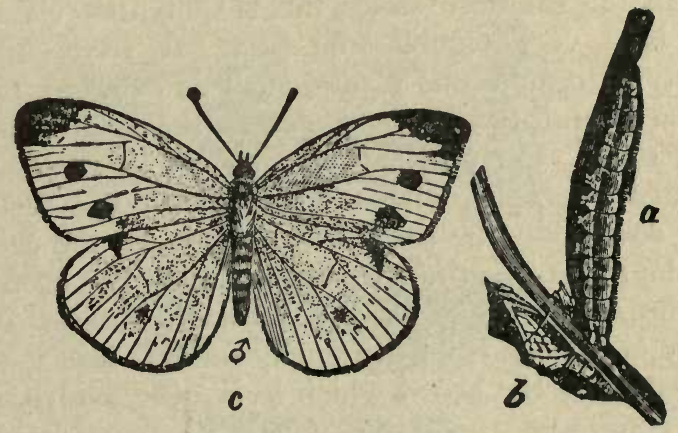

Imported Cabbage=worm

$a$, larva; $b$, chrysalis; $c$, female butterfly. (After Riley)

occurs in great numbers on the leaves and in the heads of cabbage. During the summer months it reproduces viviparously, but in autumn true males and females are developed, eggs being deposited by the latter upon the cabbage leaves.

Remedy-Kerosene in mechanical mixture or emulsion and fish-oil soap are the most effective liquid insecticides that can be used against this insect.

Young cabbages are often attacked by flea-beetles, especially the WAVy-STRIPED FLEA-BeEtle. It is a small, shining black beetle, I-Io inch long, with a 
broad, yellow, wavy stripe on each wing-cover It feeds upon the surface of the leaf, gnawing out little pits. The females deposit minute whitish eggs upon the roots of cruciferous plants, such as radish, cabbage, turnip, etc, and the larvae feed upon these roots, sometimes doing serious damage. The full-grown larva is about $1 / 4$ inch long, with a yellowish-white body, and brown head.

Remedies-Spray the plants with a strong tobacco decoction, or dust on powdered tobacco.

In the southern states the HARLEQUiN CABBAGEBUG is a very troublesome pest. It feeds upon a variety of cruciferous plants, such as cabbage, radish, mustard, and turnip; and passes the winter in the adult state. Early in spring eggs are deposited upon mustard or radish plants, upon which the resulting bugs develop. The second brood attacks the cabbage and the insects continue to develop upon this crop until autumn. According to $\mathrm{Mr}$ Howard Evarts Weed, "there is but one efficient remedy for this insect, which is, to destroy the brood which lives over winter, when they congregate upon the mustard or radish plants. Here they may be destroyed very easily by the application of kerosene (not emulsified) by means of a hand force-pump or common watering bucket. If the insects are thus destroyed early in the season, it will almost wholly prevent injury later. The insects fly but little, and are thus not apt to come from a neighboring field." Those bugs or eggs which may be seen on cabbage should be picked off and destroyed.

\section{ASPARAGUS}

The Asparagus Rust is a very destructive fungous disease in some regions. The damage it does varies greatly from year to year. Experiments in 
New York, Delaware and other states show that its injuries may be prevented to a great extent by spraying with Bordeaux mixture to which rosin soap has been added to make it adhere better. Professor F. D. Chester's recommendations are as follows: "Dissolve 2 pounds of the rosin soap in the necessary quantity of water and add to the Bordeaux mixture, which is prepared in the ordinary way. The first application in this section should be made about the middle of July and repeated about two weeks later. The eco-
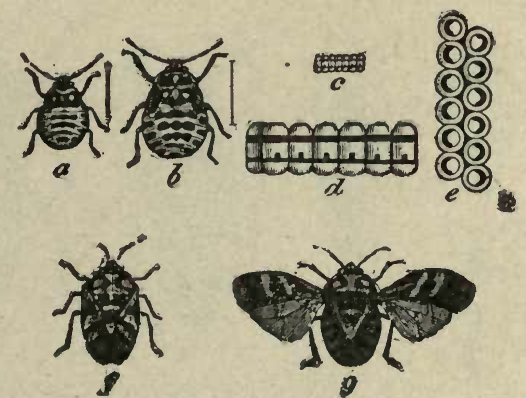

Harlequin Cabbage=-bug

$a, b$, nymphs; $c$, eggs; $f$, adult; $g$, adult with wings extended-all natural size; $d$ eggs, side view; $e$, eggs, view from above $-d, e$, enlarged. (After Riley)

nomical spraying of asparagus demands a specially devised spraying outfit, and should consist of a cart with wheels sufficiently high so that the axles will brush only the tops of the plants. On this cart is mounted a barrel and a pump, the latter being connected with a length of pipe running along the back of the cart and parallel to the axles. To this horizontal pipe are attached three tees and short nipples, to which are attached the nozzles. By driving across a field in the direction of the rows a rather broad strip of plants can be sprayed as rapidly as it takes a horse to slowly pace the ground. 
"The advisability of spraying asparagus will depend on circumstances. If the rust has been serious the year before, it is to be expected that it will make its appearance on the following season, and it would be advisable to forestall its appearance by spraying. It will not do to wait until it shows itself before spraying, as it is then too late." 


\section{GRAIN CROPS}

\section{INSECT ENEMIES}

The $\mathrm{CH} i n c h$ Bug has long been recognized as one of the arch-enemies of American agriculture. The adult $(h)$ is a small blackish insect, slightly less than
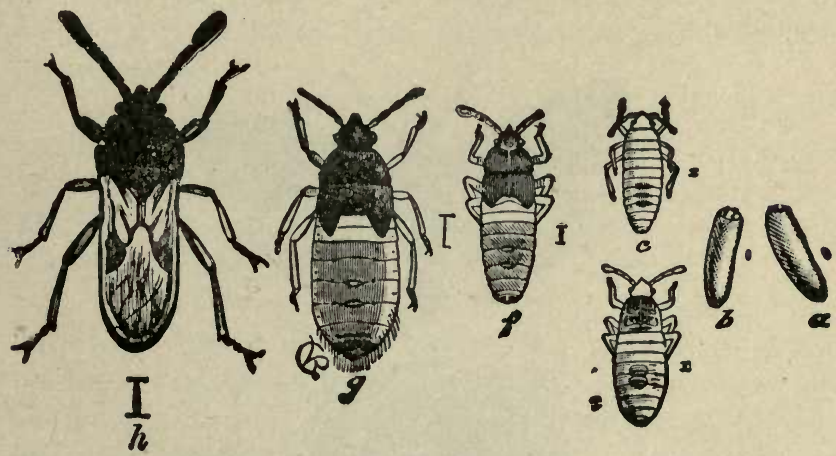

Chinch Bug

$u, b$, eggs; $c, e, f$, young; $g$, nymph or pupa; $h$, adult. Magnified (After Riley)

I-5 inch long, with the legs dark yellow, and their tips black. The females deposit eggs about the roots of grass and grain. From these hatch young bugs (c) that do not differ in general form from the adults. They suck the sap from various plants of the grass family, gradually increasing in size, and moulting at intervals. In a few weeks they become nearly fullgrown, but instead of changing to a quiet chrysalis state, they simply moult again and continue feeding as before. In these early stages, which correspond to 
the larva and chrysalis, they are called nymphs. The older nymphs $(g)$ are nearly as large as the fullgrown bugs, differing mainly in the absence of wings. In about a week they again moult and come forth as adult bugs.

Remedies-Chinch bugs are easily killed by kerosene, and by means of improved spraying machines this substance can be used against them to good advantage. The best time to choose in which to kill them is when they are migrating from field to field.
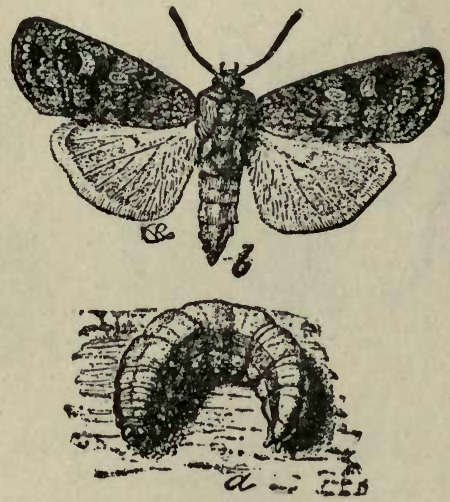

\section{Variegated $\mathrm{Cut}=$ worm}

$a$, larva; $b$, moth. (After Riley)

Corn, oats, and other field and garden crops suffer greatly from the attacks of CUT-WORMS, of which there are many species. They are larvae of medium-sized, night-flying moths, and are thick, naked worms that curl up when disturbed. Most of them feed upon grass or clover when young, becoming about half grown by winter time, when they seek the shelter of some log or stone, or burrow into the soil. Here they hibernate, and in spring come forth 
in search of food. They now attack a variety of young plants, biting off the stems and feeding upon the leaves. They become full-grown in spring or in early summer, and pupate beneath the soil surface, and three or four weeks later emerge as moths. The larva $(a)$ and moth $(b)$ of the Variegated Cutworm (Agrotis sancia) are represented, natural size, on page I30. Some species have two or more broods each season, while others have but one. Cut-worms are especially likely to do damage in fields and gardens close to grass-lands, and to crops immediately following grass.

Remedies-Spray a small plat of clover with an arsenical poison and then cut it late in the afternoon and strew in bunches over the field to be protected. The worms prowling about at night eat of the poisonous baits and are killed.

The Army-worm hatches from eggs laid by a handsome brown moth between the sheaths of grass blades. The larvae are at first green, but later become ornamented with longitudinal stripes of yellow, gray, and black. They feed upon the leaves of grass, wheat, oats, rye, etc, and become full-grown in about a month. Occasionally they become so numerous that they exhaust their food supplies, and then are forced to seek other feeding grounds. At such times the "armies" appear, and moving in solid masses sweep all grasses and cereals before them. The larvae pupate in earthen cells, emerging a fortnight later as moths.

Remedics-One of the most promising methods of combating this insect is that of thoroughly spraying strips of grass or other crops in front of the advancing host with mixtures of arsenate of lead and water. 


\section{DOMESTIC ANIMALS}

\section{INSECT ENEMIES}

Our various domestic animals frequently suffer from the attacks of LicE. Three of the commoner species affecting horses and cattle are shown below. Animals affected by them lose flesh and are weakened. The lice generally deposit their eggs or "nits" on the hairs.

Remedy-The best method of destroying lice is to spray or wash the infested animals with a wellprepared kerosene emulsion. If this is well made it
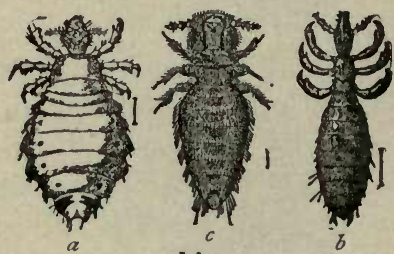

Lice

$a, b$, sucking ox-lice; $c$, biting horse-louse. Magnified. (After Osborn)

can be applied to cattle and horses, hogs and sheep, with no danger of injury to them, while it will destroy all the lice with which it comes in contact. Professor C. P. Gillette, who first gave this method a thorough trial, recommends applying it with a force-pump and spray nozzle, rubbing it in thoroughly with the finger tips at the same time. It kills the lice, and leaves the hair of the animal in good condition. The lice may also be destroyed by treating with a strong tobacco decoction - a pound of tobacco being boiled 
in two gallons of water-or a wash of carbolic-acid soap. But the first-named remedy is best. The stalls and woodwork of the quarters occupied by the in fested animals should also be treated.

The HORN FLY is a recently imported insect that often annoys cattle by sucking their blood and lighting upon their horns. The eggs are deposited in freshly dropped cow-dung, in which the larvae

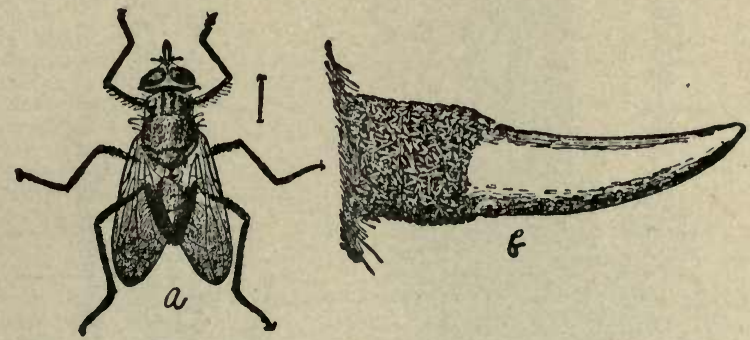

Horn Fly

magnified

Cow horn

with band of resting flies, reduced

(From Insect Life)

devclop, and pupate in the soil beneath. There are four or five broods each season. During hot weather the transformations of the insect-from egg to imago-may be completed within two weeks.

Remedics-Spray cattle twice a week, either with kerosene emulsion, to which a little tobacco decoction has been added, or fish-oil, to which a little carbolic acid has been added. Or rub on by means of a brush or cloth. One stockman has had good success by simply dampening the tips of the hairs with a rag dipped in crude petroleum. 

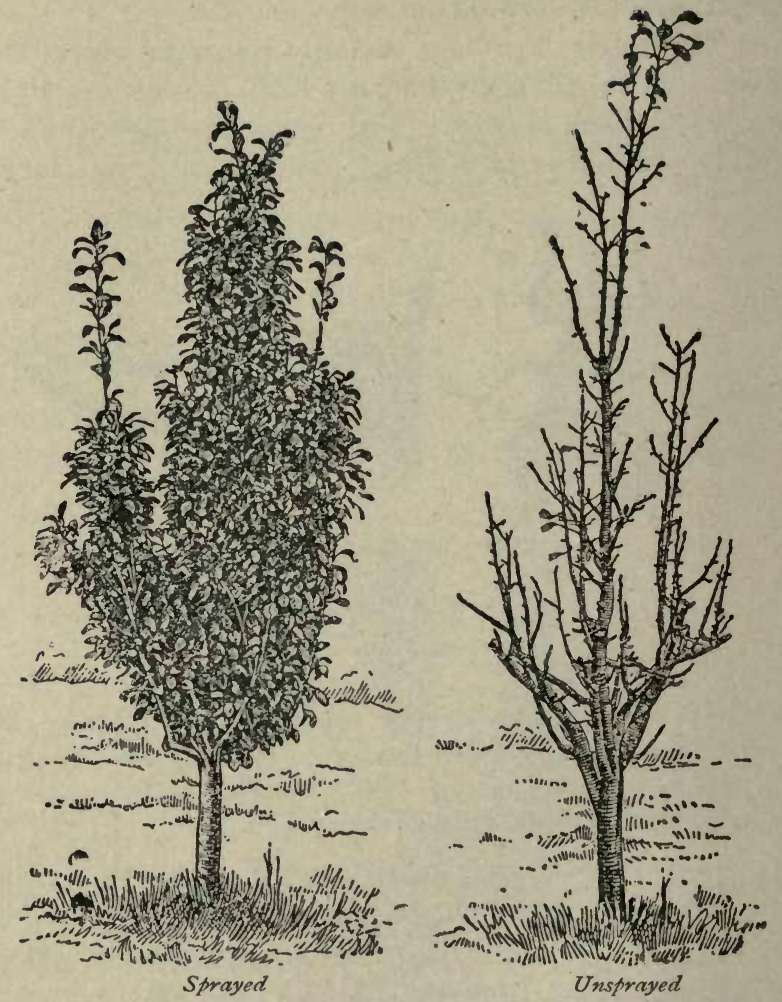

Pear Leaf=blight Experiment-See page 78

(After Galloway) 


\section{In $d$ e $x$}

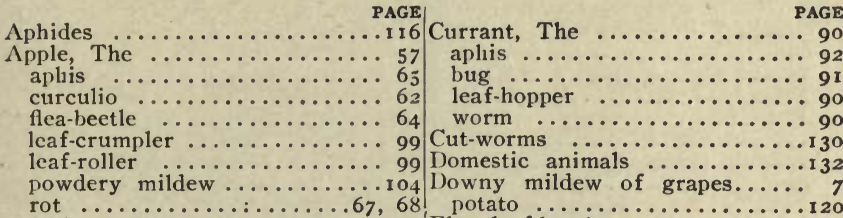

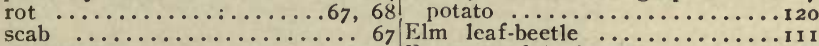

skeletonizer ............ roo Eye-spotted bud-moth ........66 66

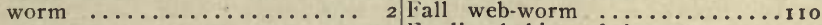

Army-worm .............. I 31 Fecding-habits of insects..... 6

Arsenate of lead............ I 2 lisli-oil soap $\ldots \ldots \ldots \ldots \ldots \ldots$. 8

senite of lime.......................... Flowers

Arsenites and copper carbonatc. . 30 Formaldehyde-glycerine mixture. 28

Asparagus rust $\ldots \ldots \ldots \ldots \ldots \ldots$ i 26 Four-lined leaf-bug ........ 9 r

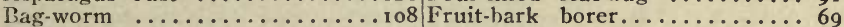

Basket-worm ............. ro8 Fungicides ............. I9

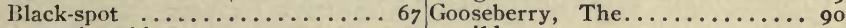

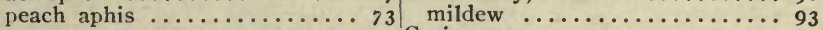

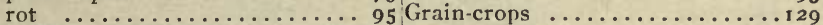

Bordeaux mixturc.......... 20 , ne, The............ 95 and arsenites............................ 95

Brown-rot of stone fruits...70, 75 Harlequin cabbage-bug .......

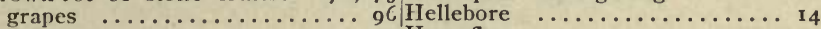

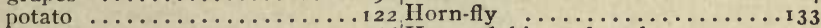

Bud-moth ............66 Hyposulphite of soda....... 27

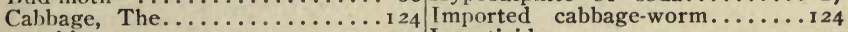

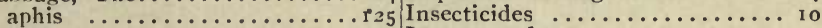
plusia $\ldots \ldots \ldots \ldots \ldots \ldots \ldots \ldots \ldots \ldots \ldots \ldots \ldots \ldots \ldots$ I 4

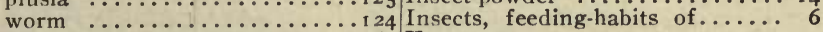

Canker-worm ...........5, $6_{3}$ Kerosene ............... 14

Carbonate of copper............ 26 Kerosene emulsion ............ I5

Cherry, The............................ Is

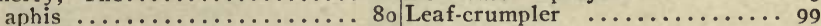

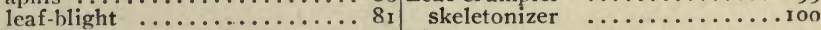

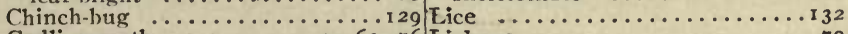
Codling-moth .......... 60,76 Lichens ................ 79

Colorado potato-beetle......... I 19 Lime-spray ................ 19

Combining insecticides and fun- Liver of sulphur........... 27 gicides $\ldots \ldots \ldots \ldots \ldots \ldots \ldots .28$ London purple $\ldots \ldots \ldots \ldots \ldots$ I 2

Cost of straying.......... 43 Lye solution $\ldots \ldots \ldots \ldots \ldots \ldots 28$

Copner carbonate ........... 26 Maple bark-louse ............ I07

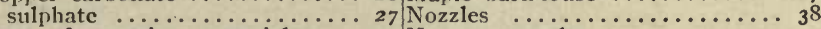

Cost of spraying materials..... 3o Nursery stock.............. 99

Crude netroleum .......... I6 Oyster-shell bark-louse.......59 
PAGE

Parasitic fungi, development of 7 Red-spider . . . . . . . . .

Paris green ............... ro Resin soap .................. 8

Peach ................ 73 Rose leaf-hopper ........... II5

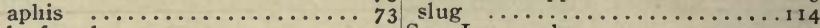

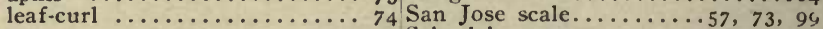

rot $\ldots \ldots \ldots \ldots \ldots \ldots \ldots \ldots \ldots \ldots \ldots \ldots \ldots$ is

Pear, The.............................. 76 Shade trees

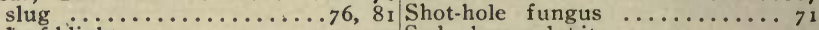

leaf-blight $\ldots \ldots \ldots \ldots \ldots 77$, I 02 Soda hyposulphite .......... 27

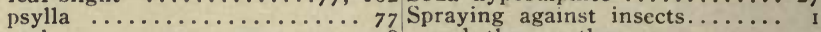

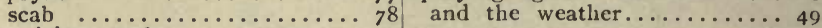

Pernicious scale.......... 57 apparatus $\ldots \ldots \ldots \ldots \ldots \ldots . \ldots \ldots 2$

Petroleum, crude .......... 16 cost of $\ldots \ldots \ldots \ldots \ldots \ldots 43$

Philosophy of spraying....... I calendar $\ldots \ldots \ldots \ldots \ldots \ldots \ldots$. 50

Plum, The..............6. 69 materials, cost of.......... 30 curculio $\ldots .4,62,69,73,76,80$ nozzles $\ldots \ldots \ldots \ldots \ldots \ldots \ldots . \ldots . \ldots$ gouger ...................69

leaf-blight $\ldots \ldots \ldots \ldots \ldots 102,104$

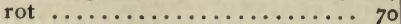

Potassium sulphide .......... 27

Potato, The .................. beetle .....................

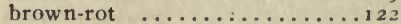

early blight ............... 120

late blight ................ 120

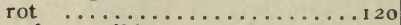

Powdery mildew ............ 02

Prejudice against spraying...... 3

Profits in

Profits in spraying......... 45 Tent caterpillar ............64

Pruning trees ....................... 50

Pyrethrum ............. I 4 Wavy-striped flca-bectle ....... I25

@uince, The .............. 79 Whale-oil soap ............ I9

Raspberry, The ............. 97 White-marked tussock-moth ...109

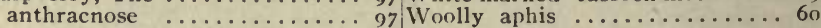

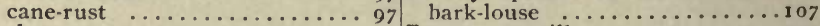
slug ........................... Z 25

Red-legged flea-bectle $\ldots \ldots \ldots .7,3$ 


\section{"One Spraying Enough" "DISPARENE"}

The Most Powerful Known Insecticide

\section{NEVER INJURES FOLIAGE}

Sticks like Paint through Season.

"DISPARENE," THE ONLY INSECTICIDE THAT WILL DESTROY BOTH BROODS OF THE CODLING MOTH, kills all leaf-eating insects-cankerworm, tussock moth, elm leaf beetle, cranberry fireworm, cut worms, brown-tail moth, gypsy moth, potato bug and similar insects.

"DISPARENE" is safer than any other insecticide; kills the insects, does not burn the leaves, and sticks like paint throughout the season, and is the only arsenical insecticide known that can be safely used at any strength on the most delicate foliage.

Prof. E. D. Sanderson, Entomologist of the Delaware Experiment Station, conducted in r $190 \mathrm{I}$ the most careful and exhaustive series of experiments ever made against the codling moth. As usual, "DISPARENE" gave the best results of any insecticide used. He writes: "I have used 'DISPARENE" against the codling moth this year. It proved to be very much superior to Paris Green, and destroyed a larger percentage of codling moth larvae than has ever been done in any similar, carefully conducted experiment. One thing which seems to me to make 'DISPARENE' of special value is its adhesive qualities-in spite of very heavy rains it remained on the trees all summer. The results which we have secured I know will be very gratifying to you, as they have been to me quite surprising."

\section{BOWKER INSECTICIDE CO.,}

43 Chatham Street, Boston, Mass.

Send for our 48-page Catalogue with illustrations from photographs af sprayed crops and descriptions of 28 kinds of spraying materials, pumps, etr. 


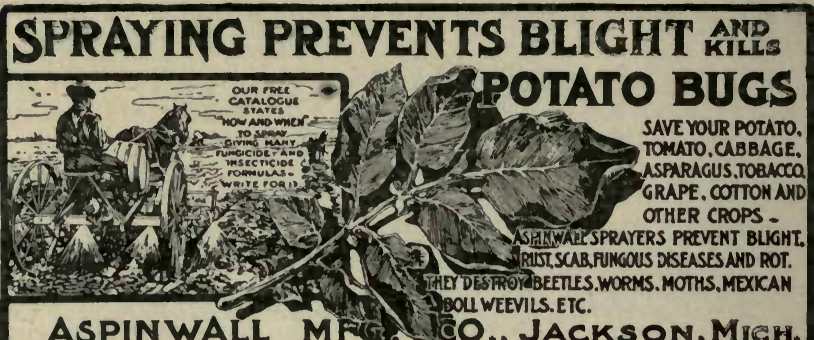

\section{A SEVERE AND PRACTICAL TEST}

Ithaca, N. Y., July 19, 1902.

Gentlemen: It gives me pleasure to report that your l'otato Sprayer is a great success. It does its work efticlently and quickly. I can now perform the work of spraying potatoes in one-quarter of the time formerly required, and one man and a horse will do the work which formerly required the services of three men and a horse. I shall hereafter recommend your sprayer to those who inquire of me where a good machine can be secured.

Yours very truly, L. A. CLINTON, Assistant Agriculturist, Cornell University Agr'l Experiment Sta.

\section{LONDON PURPLE}

To obtain soUND, IANISOME FRUIT spray with LONDON PIRPLE (trade - mark), which has been the popular, safe and

Effective Insecticide

for use against Potato Bugs, Cotton Worms, CANKRir Worms, CoDling Moth, Curculio, etc., for more than a

Q U A R T T E R

Thousands of tons have been used, ensuring in manufacture a perfection only attained by vast experience. LONIOON PURILE is exactly suited for farmers' and fruit growers' uses. Write for circular. Manufactured solely by

HEMINGWAY'S LONDON PURPLE CO., Ltd., 133 Front Street, New York.

Works: Marsh fiate Lane, Stratford, London, England. 
By H. Nicholas Jarchow, LL. D. A treatise on the care of woodlands and the restoration of the denuded timberlands on plains and mountains. The author has fully described those European methods which have proved to be most useful in maintaining the superb forests of the old world. This experience has been adapted to the different climates and trees of America, full instructions being given for forest planting of our various kinds of soil and subsoil, whether on mountain or valley. Illustrated. 250 pages. $5 \times 7$ inches. Cloth. \$1.50

\section{Soils and Crops of the Farm.}

By George E. Morrow, M. A., and Thomas F. Hunt. The methods of making availabie the plant food in the soil are described in popular language. A short history of each of the farm crops is accompanied by a discussion of its culture. The useful discoveries of science are explained as applied in the most approved methods of culture. Illustrated. 310 pages. $5 \times 7$ inches. Cloth. . . . . . \$1.00

\section{I and Draining.}

A handbook for farmers on the principles and practice of draining, by MANLY MiLes, giving the results of his extended experience in laying tile drains. The directions for the laying out and the construction of tile drains will enable the farmer to avoid the errors of imperfect construction, and the disappointment that must necessarily follow. This manual for practical farmers will also be found convenient for reference in regard to many questions that may arise in crop growing, aside from the special subjects of drainage of which it treats. Illustrated. 200 pages. $5 \times 7$ inches. Cloth. . . \$1.00

\section{Barn Plans and Outbuildings.}

Two hundred and fifty-seven illustrations. A most valuable work, full of ideas, hints, suggestions, plans, etc., for the construction of barns and outbuildings, by practical writers. Chapters are devoted to the economic erection and use of barns, grain barns, horse barns, cattle barns, sheep barns, cornhouses, smokehouses, icehouses, pig pens, granaries, etc. There are likewise chapters on birdhouses, doghouses, tooi sheds, ventilators, roofs and roofing, doors and fastenings, workshops, poultry houses, manure sheds, barnyards, root pits, etc. 235 pages. $5 \times 7$ inches. Cloth. •. . $\$ 1.00$ 


\section{Herbert's Hints to Horse Keepers.}

By the late Henry William Herbert (Frank Forester). This is one of the best and most popular works on the horse prepared in this country. A complete manual for horsemen, embracing: How to breed a horse; how to buy a horse; how to break a horse; how to use a horse; how to feed a horse; how to physic a horse (allopathy or homeopathy); how to groom a horse; how to drive a horse; how to ride a horse, etc. Beautifully illustrated. 425 pages. $5 \times 7$ inches. Cloth. . . . . . . . \$1.50

\section{Discases of Horses and Cattle.}

By DR. D. McIntosh, V. S., professor of veterinary science in the university of Illinois. Written expressly for the farmer, stockman and veterinary student. A new work on the treatment of animal diseases, according to the modern status of veterinary science, has become a necessity. Such an one is this volume of over 400 pages, written by one of the most eminent veterinarians of our country. Illustrated. 426 pages. $5 \times 7$ inches. Cloth. • • • • \$1.75

\section{The Ice Crop.}

By Theron L. Hiles. How to harvest, ship and use ice. A complete, practical treatise for farmers, dairymen, ice dealers, produce shippers, meat packers, cold storers, and all interested in icchouses, cold storage, and the handling or use of ice in any way. Including many recipes for iced dishes and beverages. The book is illustrated by cuts of the tools and machinery used in cutting and storing ice, and the different frrms of icehouses and cold storage buildings. Illustrated. 122 pages. 5x7 inches. Cloth. : • • \$1.00

The Secrets of Health, or How Not to Be Sick, and - How to Get Well from Sickness.

By S. H. Platt, A. M., M. D., late member of the Connecticut Eclectic Medical Society, the National Eclectic Medical Association, and honorary member of the National Bacteriological Society of America; our medical editor and author of "Talks With Our Doctor" and "Our Health Adviser." Nearly 600 pages. An index of 20 pages, so that any topic may be instantly consulted. A new departure in medical knowledge for the people-the latest progress, secrets and practices of all schools of healing made available for the common peoplehealth without medicine, nature without humbug, common sense without folly, science without fraud. 8I illustrations. 576 pages. $5 \times 7$ inches. Cloth. . . . \$1.50 


\section{STANDARD BOOKS.}

Hunter and Trapper.

By Halsey Thrasher, an old and experienced sportsman. The best modes of hunting and trapping are fully explained, and foxes, deer, bears, etc., fall into his traps readily by fol. lowing his directions. Illustrated. 92 pages. $5 \times 7$ inches. Cloth.

Batty's Practical Taxidermy and Home Decoration.

By Joseph H. BatTy, taxidermist for the government surveys and many colleges and museums in the United States. An entirely new and complete as well as authentic work on taxidermy-giving in detail full directions for collecting and mounting animals, birds, reptiles, fish, insects, and general objects of natural history. I25 illustrations. 204 pages. $5 \times 7$ inches. Cloth. . . . . . \$1.00

\section{Hemp.}

By S. S. Boyce. A practical treatise on the culture of hemp for seed and fiber, with a sketch of the history and nature of the hemp plant. The various chapters are devoted to the soil and climate adapted to the culture of hemp for seed and for fiber, irrigating, harvesting, retting and machinery for handling hemp. Illustrated. II 2 pages. $5 \times 7$ inches. Cloth.

Alfalfa.

By F. D. Coburn. Its growth, uses and feeding value. The fact that alfalfa thrives in almost any soil; that without reseeding, it goes on yielding two, three, four and sometimes five cuttings annually for five, ten, or perhaps 100 years; and that either green or cured it is one of the most nutritious forage plants known, makes reliable information upon its production and uses of unusual interest. Such information is given in this volume for every part of America, by the highest authority. Illustrated. 164 pages. $5 \times 7$ inches. Cloth. \$0.50

\section{Talks on Manure.}

By Joseph Harris, M. S. A series of familiar and practical talks between the author and the deacon, the doctor, and other neighbors, on the whole subject of manures and fertilizers; including a chapter especially written for it by Sir John Bennet Lawes of Rothamsted, England. 366 pages. $5 \times 7$ inches. Cloth. 


\section{Practical Forestry.}

By ANDREW S. Fuller. A treatise on the propagation, planting and cultivation, with descriptions and the botanical and popular names of all the indigenous trees of the United States, and notes on a large number of the most valuable exotic species. Illustrated. 300 pages. $5 \times 7$ inches. Cloth. . . . . . . $\$ 1.50$ Irrigation for the Farm, Garden and Orchard.

By Henry Stewart. This work is offered to those American farmers and other cultivators of the soil who, from painful experience, can readily appreciate the losses which result from the scarcity of water at critical periods. Fully illustrated. 276 pages. 5x7 inches. Cloth. . . \$1.06 Irrigation Farming.

By LUte Wilcox. A handbook for the practical application of water in the production of crops. A compiete treatise on water supply, canal construction, reservoirs and ponds, pipes for irrigation purposes, flumes and their structure, methods of applying water, irrigation of field crops, the garden, the orchard and vineyard, windmills and pumps, appliances and contrivances. New edition, revised, enIarged and rewritten. Prof usely illustrated. Over 500 pages. 5x7 inches. Cloth. . . . . . \$2.00 Ginseng, Its Cultivation. Harvesting, Marketing and Market Value.

By MaUrice G. KaINS, with a short account of its history and botany. It discusses in a practical way how to begin with either seed or roots, soil, climate and location, preparation, planting and maintenance of the beds, artificial propagation, manures, enemies, selection for market and for improvement, preparation for sale, and the profits that may be expected. This booklet is concisely written, well and profusely illustrated, and should be in the hands of all who expect to grow this drug to supply the export trade, and to add a new and profitable industry to their farms and gardens, without interfering with the regular work. New edition. Revised and en larged. Illustrated. $5 \times 7$ inches. Cloth. . • • \$0.5a Truck Farming at the South.

By A. Oemier. A work giving the experience of a suc. cessful grower of vegetables or "garden truck" for northerr markets. Essential to anyone who contemplates entering this profitable field of agriculture. Illustraied. 274 pages. 5x7 inches. Cloth. 


\section{STANDARD BOOKS.}

\section{Henderson's Practical Floriculture.}

By Peter Henderson. A guide to the successful propagation and cultivation of florists' plants. The work is not one for florists and gardeners only, but the amateur's wants are constantly kept in mind, and we have a very complete treatise on the cultivation of flowers under glass, or in the open air, suited to those who grow flowers for pleasure as well as those who make them a matter of trade. New and enlarged edition. Beautifully illustrated. 325 pages. $5 \times 7$ inches. Cloth. $\$ 1.50$

Mushrooms. How to Grow Them.

By William Falconer. This is the most practical work on the subject ever written, and the only book on growing mushrooms published in America. The author describes how he grows mushrooms, and how they are grown for profit by the leading market gardeners, and for home use by the most successful private growers. Engravings drawn from nature expressly for this work. 170 pages. $5 \times 7$ inches. Cloth. \$1.00

\section{Play and Profit in My Garden.}

By E. P. Roe. The author takes us to his garden on the rocky hillsides in the vicinity of West Point, and shows us how out of it, after four years' experience, he evoked a profit of $\$ 1000$, and this while carrying on pastoral and literary labor. It is very rarely that so much literary taste and skill are mated to so much agricultural experience and good sense. Illustrated. 350 pages. $5 \times 7$ inches. Clnth. • • \$1.00

Fumigation Methods.

By Willis G. Johnson. A timely up-to-date book on the practical application of the new methods for destroying insects with hydrocyanic acid gas and carbon bisulphid, the most powerful insecticides ever discovered. It is an indispensable book for farmers, fruit growers, nurserymen, gardeners, florists, millers, grain dealers, transportation companies, college and experiment station workers, etc. Illustrated. pages. 5x7 inches. Cloth. . . . . \$1.00 Fungi and Fungicides.

By Prof. Clarence M. Ween. A practical manual concerning the fungous diseases of cultivated plants and the means of preventing their ravages. The author has endeavored to give such a concise account of the most important facts relating to these as will enable the cultivator to combat them intelligently. 90 illustrations. 222 pages. $5 \times 7$ inches. Paper, 50 cents; cloth . . . . . \$1.00 


\section{STANDARD BOOKS.}

\section{Insects and Insecticides.}

By Clarence M. Weed, D. Sc., professor of entomology and zoology, New Hampshire college of agriculture. A practical manual concerning noxious insects, and methods of preventing their injuries. Many illustrations. 334 pages. $5 \times 7$ inches. Cloth. . . . . . . \$1.50

How Crops Grow.

By Prof. Samuel W. Johnson of Yale college. New and revised edition. A treatise on the chemical composition, structure and life of the plant. This book is a guide to the knowledge of agricultural plants, their composition, their structure and modes of development and growth; of the complex organization of plants, and the use of the parts; the germination of seeds, and the food of plants obtained both from the air and the soil. The book is indispensable to all real students of agriculture. With numerous illustrations and tables of analysis. $4 \mathrm{I} 6$ pages. $5 \times 7$ inches. Cloth. \$I.50

\section{Tobacco Leaf.}

By J. B. Killebrew and Herbert Myrick. Its Culture and Cure, Marketing and Manufacture. A practical handbook on the most approved riethods in growing, harvesting, curing, packing and selling tobacco, with an account of the operations in every department of tobacco manufacture. The contents of this book are based on actual experiments in field, curing barn, packing house, factory and laboratory. It is the only work of the kind in existence, and is destined to be the standardipractical and scientific authority on the whole subject of tobacco for many years. 506 pages and 150 original engravings. $5 \times 7$ inches. Cloth. . . . . . $\$ 2.00$

Coburn's Swine Husbandry.

By F. D. Coburn. New, revised and enlarged edition. The breeding, rearing and management of swine, and the prevention and treatment of their diseases. It is the fullest and freshest compendium relating to swine breeding yet offered. Illustrated. $3 \mathrm{I} 2$ pages. $5 \times 7$ inches. Cloth. \$1.50 Home Pork Making.

The art of raising and curing pork on the farm. By A. W. Fulton. A complete guide for the farmer, the country butcher and the suburban dweller, in all that pertains to hog slaughtering, curing, preserving and storing pork productfrom scalding vat to kitchen table and dining room. Illustrated. I25 pages. $5 \times 7$ inches. Cloth. . . . \$0.50 

GENERAL LIBRARY

UNIVERSITY OF ,CALIFORNIA-BERKELEY

RETURN TO DESK FROM WHICH BORROWED

This book is due on the last date stamped below, or on the date to which renewed.

Renewed books are subject to immediate recall.

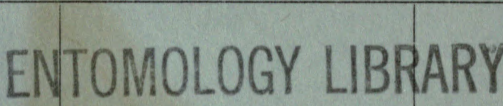


U.C. BERKELEY LIBRARIES

|||||||||||||||||||||||||||||||| c037234311

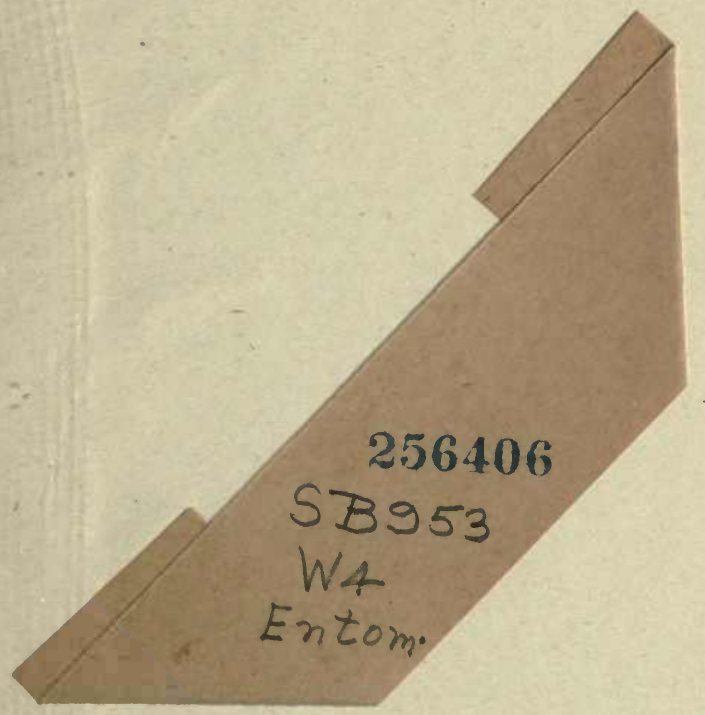




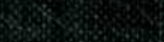

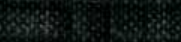

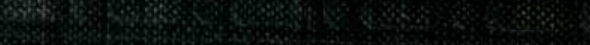

s.

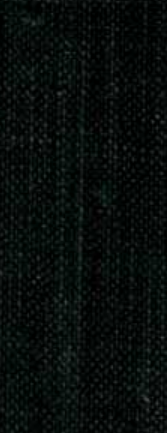

